\title{
State Sovereignty and the Tenth and Eleventh Amendments
}

\author{
Calvin R. Massey†
}

\section{The Eleventh Amendment is deceptively simple:}

The Judicial power of the United States shall not be construed to extend to any suit in law or equity, commenced or prosecuted against one of the United States by Citizens of another State, or by Citizens or Subjects of any Foreign State. ${ }^{1}$

Yet, in recent years, a vigorous debate has emerged about the meaning and history of the Eleventh Amendment. ${ }^{2}$ The conven-

$\dagger$ Assaciate Professor of Law, University of California, Hastings College of the Law. B.A., 1969, Whitman College; M.B.A., 1971, Harvard University; J.D., 1974, Columbia University. I am grateful to Hastings College of the Law for its generous financial support.I wish to thank my colleagues and friends Willie Fletcher, Ray Forrester, Mary Kay Kane, William Lockhart, Leo O'Brien, James Weinstein, and my wife, Martha Massey, for their helpful comments and suggestions on earlier drafts. I also thank John M. Sinclair for his research assistance. The errors and omissions are all mine.

1 US Const, Amend XI.

2 The debate has sharply divided the Supreme Court, four members of which urge that Hans $v$ Louisiana, 134 US 1 (1890), the principal monument to the conventional understanding, be overruled. See Welch v State Dept. of Highways \& Public Transp., $107 \mathrm{~S} \mathrm{Ct}$ 2941, 2958 (1987) (Brennan dissenting, joined by Marshall, Blackmun, and Stevens); Green $v$ Mansour, 474 US 64, 74 (1985) (Brennan dissenting, joined by Marshall, Blackmun, and Stevens); Atascadero State Hospital v Scanlon, 473 US 234, 247 (1985) (Brennan dissenting, joined by Marshall, Blackmun, and Stevens). Justice Kennedy has not had an opportunity to express himself on this subject; his predecessor, Justice Powell, was a firm adherent to the conventional wisdom embodied by Hans. See Welch, $107 \mathrm{~S} \mathrm{Ct} 2941$ (plurality opinion of Powell). Justice Scalia avoided the issue when it was obliquely presented in Welch. See Welch, $107 \mathrm{~S} \mathrm{Ct}$ at 2957-58 (Scalia concurring in part and concurring in the judgment).

While the academic commentary contains a variety of explanations of the Eleventh Amendment, nearly all of it is critical of the conventional understanding that has been persuasive to a majority of the Supreme Court. See, for example, John V. Orth, The Judicial Power of the United States: The Eleventh Amendment in American History 74-77 (Oxford, 1987) ("The Judicial Power"); Clyde E. Jacobs, The Eleventh Amendment and Sovereign Immunity 160-64 (Greenwood, 1972); Laurence H. Tribe, American Constitutional Law 173-195 (Foundation, 2d ed 1988); Akhil Reed Amar, Of Sovereignty and Federalism, 96 Yale L J 1425, 1466-92 (1987); William A. Fletcher, A Historical Interpretation of the Eleventh Amendment: A Narrow Construction of an Affirmative Grant of Jurisdiction Rather than a Prohibition Against Jurisdiction, 35 Stan L Rev 1033 (1983); Martha A. Field, The Eleventh Amendment and Other Immunity Doctrines, $126 \mathrm{U} \mathrm{Pa} \mathrm{L}$ Rev 515 (Part I), and $126 \mathrm{U} \mathrm{Pa}$ L Rev 1203 (Part II) (1978); John J. Gibbons, The Eleventh Amendment and State Sovereign Immunity: A Reinterpretation, 83 Colum L Rev 1889 (1983); David L. Shapiro, Wrong Turns: The Eleventh Amendment and the Pennhurst Case, 98 Harv L Rev 61, 
tional interpretation, which still commands at least a plurality of the Supreme Court, ${ }^{3}$ is that the amendment made constitutional an original understanding that the states were immune from private suits in the federal courts. According to this interpretation, the amendment created a presumptive jurisdictional bar to private claims in federal court against states, ${ }^{4}$ in the absence of either the state's consent or an explicit congressional abrogation of the state's immunity. ${ }^{5}$ The conventional doctrine has its modern origin in Hans $v$ Louisiana ${ }^{6}$ an 1890 opinion that construed the amendment to grant to the states this broad right of sovereign immunity. The amendment was a reaction to the Supreme Court's 1793 decision in Chisholm $v$ Georgia, ${ }^{7}$ which upheld federal jurisdiction over a suit against a state by a citizen of another state. This decision, according to the Court in Hans, created "a shock of surprise throughout the country"s by altering what had supposedly been the original constitutional understanding that the states would be immune from suit in federal court without their consent. The Eleventh Amendment merely restored that original understanding.

The revisionist interpretation of the Eleventh Amendment generally holds that the amendment was intended merely as a narrow limitation upon the state-citizen diversity clause of Article III. ${ }^{\ominus}$ The revisionists assert variously that the amendment has no independent prohibitory force, ${ }^{10}$ that it simply fails to authorize certain party based assertions of federal jurisdiction and does not limit the

67-71 (1984); John E. Nowak, The Scope of Congressional Power to Create Causes of Action Against State Governments and the History of the Eleventh and Fourteenth Amendments, 75 Colum L Rev 1413 (1975).

s See, for example, Welch v State Dept. of Highways \& Public Transp., 107 S Ct 2941 (1987) (plurality opinion of Powell).

4ennhurst State School \& Hospital v Halderman, 465 US 89 (1984); Edelman v Jordan, 415 US 651, 678 (1974) (the Eleventh Amendment "sufficiently partakes of the nature of a jurisdictional bar so that it need not be raised in the trial court"). The Supreme Court is by no means consistent in this characterization; Eleventh Amendment doctrine has also been described as an example of the fundamental principle of sovereign immunity or an embodiment of the federalist ideal of state sovereignty. The confusion of labels is not helped by the Court's propensity to employ all three at once. See, for example, Pennhurst, 465 US $89,98,100,116-117$ (1984). See also note 14 .

${ }^{8}$ Atascadero State Hospital v Scanlon, 473 US 234, 242 (1985).

${ }^{8} 134$ US 1 (1890).

22 US (2 Dall) 419 (1793).

${ }^{8}$ Hans, 134 US at 11 (1890).

- See Fletcher, 35 Stan L Rev at 1062 (cited in note 2) ("the amendment was designed merely to require a limiting construction of the state-citizen diversity clause"); Amar, 96 Yale L J at 1482-83 (cited in note 2). The "revisionists" are not a monolithic bloc; no suggestion is made here that each revisionist shares all the views of the other revisionists.

${ }^{10}$ See Field, $126 \mathrm{U} \mathrm{Pa} \mathrm{L} \mathrm{Rev} \mathrm{at} 549$ (cited in note 2). 
federal courts' power to hear suits against states founded upon a federal question, ${ }^{11}$ and that, in any case, Congress may use its powers to strip the states of whatever sovereign immunity was conferred upon them by virtue of the Eleventh Amendment. ${ }^{12}$

Both positions abound with difficulties. The conventional view takes great liberties with the amendment's text, for it operates to foreclose private claims in federal court against a state by its own citizens that arise under federal statutory or constitutional law. The text of the amendment is wholly silent about such claims, yet since Hans they have been barred because it would be "anomalous" to permit them. ${ }^{13}$ Moreover, by endorsing congressional abrogation of state sovereign immunity, the conventional doctrine indulges in an untenable analytical process. It construes the Eleventh Amendment as a bar to the exercise of federal subject matter jurisdiction and simultaneously embraces the curious notion that Congress may still confer such jurisdiction on the federal courts by statutorily abrogating the constitutionally mandated bar of state sovereign immunity. ${ }^{14}$ Almost as odd is the century old doctrine that the states may confer jurisdiction on the federal courts by waiving the constitutional barrier. ${ }^{15}$ If the amendment

11 See Welch, $107 \mathrm{~S}$ Ct at 2964-68 (Brennan dissenting); Atascadero, 473 US at 247-304 (Brennan dissenting); Gibbons, 83 Colum L Rev at 1934-38 (cited in note 2).

12 See Tribe, American Constitutional Law 178-89 (cited in note 2); Nowak, 75 Colum L Rev 1468-69 (cited in note 2).

13 Hans, 134 US at 10.

14 The Court's clearest indication that it believes the Eleventh Amendment constitutionalizes state sovereign immunity as a barrier to the exercise of federal jurisdiction may be seen in Pennhurst, 465 US 89 (1984); Green v Mansour, 474 US 64(1985); and Edelman $v$ Jordan, 415 US 651, 677-78 (1974). Professor Tribe concurs. Tribe, American Constitutional Law $191 \mathrm{n} 6$ (cited in note 2). Yet the Court plainly concedes both the legitimacy of congressional abrogation of this doctrine and conferral of jurisdiction by a state's consent. Atascadero State Hospital v Scanlon, 473 US 234 (1985) (congressional abrogation); Fitzpatrick v Bitzer, 427 US 445 (1976) (same); Edelman v Jordan, 415 US 651 (1974) (consent); Clark v Barnard, 108 US 436, 447-48 (1883) (same). These twin positions seemingly repudiate the settled axioms that the limitations of Article III jurisdiction can not be expanded by legislation, Marbury v Madison, 5 US (1 Cranch) 137 (1803), nor by consent. Louisville \& Nashville R.R. v Mottley, 211 US 149, 152 (1908) (federal question jurisdiction); Mansfield, Coldwater \& Lake Mich. Ry. v Swan, 111 US 379 (1884) (diversity jurisdiction). It may be that the Fourteenth Amendment implicitly repeals the Eleventh Amendment so that the Congress has the power to confer jurisdiction within the limits of $\S 5$ of the Fourteenth Amendment. See Fitzpatrick v Bitzer, 427 US 445, 451-56 (1976). If so, the continuing existence of any state sovereign immunity in Fourteenth Amendment cases can only be justified as a prudential limitation derived from the Tenth Amendment rather than as a jurisdictional bar imposed by the Eleventh Amendment.

${ }^{13}$ See Edelman $v$ Jordan, 415 US 651, 671-74 (1974). Compare Clark v Barnard, 108 US 436, 447-48 (1883) (state may waive sovereign immunity because immunity is conceptually like a personal right). A doctrinal justification is that the Eleventh Amendment is not jurisdictional at all; it merely confers a waivable immunity. Proponents of this reading must 
constitutionalized state sovereign immunity, it did so not by creating a waivable immunity doctrine, but by carving out of the federal judicial power a class of cases: private claims against states. As a result of this prohibition upon subject matter jurisdiction, the federal judiciary lacks any constitutional authority to hear and decide such cases. It is a miraculous doctrine that enables either Congress or a litigant state to confer this authority. ${ }^{16}$

The revisionist position carries its own conceptual baggage. Much of the revisionists' argument is historical. They contend that the Eleventh Amendment was never intended to do more than restrict the scope of the state-citizen diversity clause in order to frustrate foreign creditors, ${ }^{17}$ and that the amendment was so interpreted prior to the Reconstruction..$^{18}$ While some academics might contend that history is simply not relevant, ${ }^{19}$ the larger problem with the revisionists' historical argument is that it is unpersuasive. The historical facts relied upon by the revisionists serve as readily to refute as to confirm their conclusions. ${ }^{20}$

Some revisionists, such as Professor Amar, offer an argument that is more conceptual than historical. Having argued that the

necessarily contend that the amendment employs the language of jurisdiction to create a personal immunity rule. Moreover, early cases dealing with the immunity from suit of foreign governments make plain that foreign sovereign immunity exists not by right of the foreign nation, but by the consent of the forum nation. See, for example, The Schooner Exchange v McFaddon, 11 US (7 Cranch) 116, 136 (1812) (Writing for the Court, Chief Justice Marshall stated that "[t]he jurisdiction of the nation within its own territory is necessarily exclusive and absolute. It is susceptible of no limitation not imposed by itself. . . [A]ll sovereigns have consented to a relaxation in practice. . of that absolute and complete jurisdiction within their respective territories which sovereignty confers."). This resolution also meshes poorly with the text of the amendment and has never been wholeheartedly embraced by the Court, which continues to characterize the amendment as alternatively a jurisdictional bar, an exemplification of sovereign immunity, or an embodiment of federalist ideals of state sovereignty. See note 4 .

${ }^{10}$ If Congress possesses the authority to confer jurisdiction beyond the limits of Article III, it ought to be able, for example, to force the federal courts to deliver advisory opinions notwithstanding the established view that Article III does not vest the judiciary with such authority. See David P. Currie, The Constitution in the Supreme Court: The First Hundred Years, 1789-1888, 6-14 (Chicago, 1985) (discussing the origins of the advisory opinion limitation). Whatever the constitutional limitations on the Court, individual Justices have from time to time dispensed extra-judicial advice. See, for example, Bruce Allen Murphy, Fortas: The Rise and Ruin of a Supreme Court Justice 186-211 (Morrow, 1988); Alan F. Westin, Out-of-Court Commentary by United States Supreme Court Justices, 1790-1962: Of Free Speech and Judicial Lockjaw, 62 Colum L Rev 633 (1962).

${ }_{17}$ See Orth, The Judicial Power at 12-29 (cited in note 2); Gibbons, 83 Colum L Rev at 1934-38) (cited in note 2); Fletcher, 35 Stan L Rev at 1060-62 (cited in note 2).

18 See Gibbons, 83 Colum L Rev at 1968 (cited in note 2).

19 See, for example, Paul Brest, The Misconceived Quest for the Original Understanding, 60 BU L Rev 204 (1980).

${ }^{20}$ See text at notes $186-360$. 
federalist Constitution was predicated upon notions of sovereignty vested in one national people, and not their several state agencies, Amar asserts, soundly enough, that current Eleventh Amendment doctrine is incoherently at odds with this bedrock principle. To rescue the Eleventh Amendment, he conveniently ignores the debt avoidance history of the amendment and asserts that it always was intended as a:

simple elimination of two categories of diverse party jurisdiction: those involving noncitizen or foreign plaintiffs and state defendants. This jurisdictional repeal, however, was not designed as a barrier cutting across the other jurisdictional grants of Article III. The party alignments specified by the Eleventh Amendment would no longer provide an independent basis for jurisdiction (as they had in Chisholm), but the existence of such an alignment would not oust jurisdiction that was independently granted - for example, in federal question or admiralty cases. ${ }^{21}$

The thin support offered for this conclusion fails to rebut contrary historical evidence. The conceptual flaw in Amar's analysis is that he insists on believing that the Eleventh Amendment was part of his vision of the federalist Constitution. Amar discounts the possibility that the Eleventh Amendment represents a rare anti-federalist constitutional victory; were he to entertain the idea seriously, it might not seem such "an inexplicable throwback to the jurisdictional regime of the Articles of Confederation."22

If one side of the debate is historically wrong, and the other side is trapped in a conceptual quagmire, some other explanatory resolution is badly needed. I propose that we take Eleventh Amendment text and the history of its enactment at face value. The amendment sought to create a party based denial of jurisdiction to the federal courts that sweeps across all the jurisdictional heads of Article III. Just as Article III confers jurisdiction via a number of independent heads, the Eleventh Amendment constitutes a separate head for denial of jurisdiction. In a sense, the Eleventh Amendment is a jurisdictional trump card. Whatever the Article III source of jurisdiction-principally diversity or federal question-if the party alignment is within that prohibited by the Eleventh Amendment, the federal courts are deprived of jurisdic-

${ }^{21}$ Amar, 96 Yale L J at 1474-75 (cited in note 2) (footnotes omitted). See also Fletcher, 35 Stan L Rev at 1060-62 (cited in note 2).

${ }^{22}$ Id at 1477. 
tion. Since this jurisdictional denial is constitutionally mandated, parties may not confer jurisdiction by waiver nor may Congress override the ouster by legislation. While this construction immunizes the states from some private suits in federal court, this immunity is a by-product of the Eleventh Amendment's jurisdictional ouster, and not the result of a broad grant of immunity within the amendment itself. In my view, the conventional doctrine spawned by Hans is wrong primarily because it relies on the Eleventh Amendment for its constitutional foundation. The notion of state sovereign immunity embraced by Hans may have been perfectly sound, but both the dimensions of that immunity and its constitutional anchor are more properly found in the Tenth Amendment. ${ }^{23}$

When the conventional doctrine is viewed as a Tenth Amendment guarantee, and the Eleventh Amendment is seen as a head of jurisdictional denial sweeping across the landscape of Article III, many of the problems posed by the current debate are resolved. The view advanced here is consistent with constitutional text, the historical evidence surrounding adoption of the Eleventh Amendment, and the interpretation of the Eleventh Amendment prior to the Civil War. More significantly, it eliminates several thorny issues surrounding congressional abrogation of state sovereign immunity. If state sovereign immunity is reconceived as an attribute of the residual state sovereignty preserved by the Tenth Amendment, then Congress may use any of its delegated powers to invade that immunity. The principal limitation, of course, is that Congress may not confer the jurisdiction that the Eleventh Amendment expressly denies. Thus, Congress could enable the federal courts to hear claims against a state made by its own citizens asserting a violation of a federal statutory or constitutional right. Congress could not, however, enable the federal courts to hear the identical claim presented against a state by a citizen of another state.

Justice Bradley was undoubtedly correct when he observed, in Hans, that it would be anomalous to open the federal courts to federal claims against a state by its own citizens but close those courts to federal claims against a state by foreigners or citizens of

${ }^{23}$ US Const, Amend X: "The powers not delegated to the United States by the Constitution, nor prohibited by it to the States, are reserved to the States respectively, or to the people."

Justice Blackmun apparently shares this view: "[T] $]$ hough of more mature vintage, the Court's Eleventh Amendment cases spring from the same soil as the Tenth Amendment jurisprudence recently abandoned in Garcia v. San Antonio Metropolitan Transit Authority, 469 U.S. 528 (1985)." Atascadero State Hospital, 473 US at 303 (Blackmun dissenting). 
another state. ${ }^{24}$ A rule that permits the states to violate the federal rights of non-citizens and avoid direct accountability in federal court for those actions seems most peculiar, indeed, almost perverse. That, however, may be the legacy left by the "unflinchingly political"2s decision to enact the Eleventh Amendment in order to avoid state liability to British creditors and to loyalists seeking to reclaim their seized property. The contemporary consequences of this anomaly might cause the modern American polity to question whether the Eleventh Amendment should continue to enjoy constitutional status. Whatever the answer to that question, to the extent that the anomaly is unacceptable, it might be partially overcome by a legislatively mandated extension of Testa $v$ Katt $^{26}$ that would require the states to afford a state forum for the vindication of federal statutory or constitutional rights asserted against a state by a non-citizen of the defendant state.

In order to test the thesis of this article, it is useful to begin by surveying the current state of affairs in Tenth and Eleventh Amendment jurisprudence. Following this exercise, section II will summarize the history of sovereign immunity in America prior to the adoption of the Eleventh Amendment. Section III traces the history of the Eleventh Amendment in the courts prior to Reconstruction. Section IV recounts the creation of the Hans doctrine, and then attempts to recast modern state sovereign immunity doctrine as a Tenth Amendment principle. Finally, section V elaborates upon the implications of this article's proposed reconceptualization of state sovereign immunity, in part by using Pennsylvania $v$ Union $\mathrm{Gas} \mathrm{Co}^{27}$ as a paradigm case for exploring these matters.

\section{The Current Law of the Tenth and Eleventh AMENDMENTS}

\section{A. The Eleventh Amendment}

The conventional interpretation of the Eleventh Amendment is that it embodies an overarching principle of state sovereign immunity from federal court jurisdiction. This view holds that a state can never be sued by name in a federal court without its consent. ${ }^{28}$

24 Hans, 134 US at 10.

${ }^{25}$ Gibbons, 83 Colum L Rev at 2003 (cited in note 2).

${ }^{28} 330$ US 386 (1947).

${ }^{27}$ Cert granted, 108 S Ct 1219 (1988), reported below as, United States v Union Gas Co., 832 F2d 1343 (3d Cir 1987).

${ }^{28}$ Hans $v$ Louisiana, 134 US 1 (1890), is the standard citation. See, for example, Welch v State Dept. of Highways \& Public Transp., 107 S Ct 2941, 2945 (1987) (plurality opinion); 
Although the amendment purports to deny federal jurisdiction only over claims "in law or equity ... . against one of the United States by Citizens of another State, or by Citizens or Subjects of any Foreign State," text as emblematic of a much broader immunity from suit in federal court. The metamorphosis began with Hans $v$ Louisiana, which concluded that it would be "anomalous" to permit a federal claim against a state by its own citizens while denying identical claims by citizens of other states. ${ }^{30}$ In Ex parte New York (No.1), ${ }^{31}$ the Supreme Court rejected a long standing interpretation of the amendment that had treated admiralty cases as exempt from the Eleventh Amendment bar because they were not "in law or equity."32 In 1934 the erosion of the amendment's explicit party alignment limitation became complete with the decision in Monaco $v$ Mississippi $i^{33}$ that the jurisdictional bar extended to suits against states by foreign governments themselves.

Although the Court has employed the Eleventh Amendment as a symbol for state sovereign immunity, it has not pressed this immunity to its ultimate limits. In recognition of federal union the Court has construed Article III to permit the United States to sue the states, ${ }^{34}$ and the states to sue each other. ${ }^{35}$ Nor does the immunity afforded by the Eleventh Amendment extend beyond the federal courts; states are susceptible to suit by private citizens in the courts of their sister states. ${ }^{36}$ Finally, although counties and other subdivisions of a state are treated as state actors for Fourteenth

Florida Dept. of State v Treasure Salvors, Inc., 458 US 670, 683 n 17 (1982) (plurality opinion); Edelman $v$ Jordan, 415 US 651, 662-63 (1974).

29 US Const, Amend XI.

so 134 US 1,10 (1890).

31256 US 490 (1921).

32 For a discussion of the earlier cases treating private suits in admiralty as exempt from the Eleventh Amendment, see notes 299-319 and accompanying text. The Ex parte New York Court dismissed the prior tradition by concluding that state sovereign immunity "is a fundamental rule of jurisprudence ... of which the Amendment is but an exemplification." Ex parte New York 256 US at 497. This "exemplification" notion continues to echo. See Pennhurst, 465 US 89, 98-99 (1984).

s3 292 US 313 (1934).

34 United States v Mississippi, 380 US 128, 140-41 (1965).

${ }^{35}$ Rhode Island v Massachusetts, 37 US (12 Pet) 657, 672-74 (1838); North Dakota $v$ Minnesota, 263 US 365, 372-73 (1923). But if a state attempts to sue another state on behalf of a discrete group of private citizens, Eleventh Amendment immunity may successfully be invoked. See New Hampshire v Louisiana, 108 US 76, 88-91 (1883); Hawaii v Standard Oil Co., 405 US 251, 258-59 n 12 (1972). For discussion of New Hampshire v Louisiana, see Jacobs, Sovereign Immunity at 118-21 (cited in note 2); Orth, The Judicial Power at 58-70 (cited in note 2).

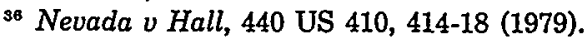


Amendment purposes, ${ }^{37}$ they are not so regarded for purposes of the Eleventh Amendment, ${ }^{38}$ and thus they partake of none of the immunity from suit available to states and their departmental "arms." 39

Because important individual federal rights can be trampled upon by the states, various doctrines and fictions have arisen over the years to ameliorate some of the harsher implications of state sovereign immunity. In $E x$ parte Young, ${ }^{40}$ the Court formulated one of the most important of these by holding that a federal court could enjoin a state officer acting in his official capacity, even though the state itself is immune from suit. The fiction of $E x$ parte Young is that if the state official's acts violate the Constitution "he is in that case stripped of his official or representative character and is subjected in his person to the consequences of his official conduct." 41

The Ex parte Young rule is no panacea, however, for its scope is restricted by the application of the abstention doctrines derived from the Court's decision in Railroad Commission v Pullman Co. ${ }^{42}$ and Younger $v$ Harris. ${ }^{43}$ These doctrines, discussed more fully in the next subsection, restrain the federal courts from enjoining state officials from allegedly unconstitutional action if there is a real possibility the case may be decided on state grounds or if a pending state court proceeding is adequate to hear the constitutional claim. In Edelman $v$ Jordan, ${ }^{44}$ the Court further limited the application of Ex parte Young to instances other than when "pri-

37 See, for example, Home Tel. \& Tel. Co. v City of Los Angeles, 227 US 278 (1913). Compare Monell v Dept. of Social Services, 436 US 658, 690-91 (1978) (finding political subdivisions of a state to be "persons" susceptible to private damage suits under 42 USC \& 1983); and Smith v State, 428 Mich 540, 410 NW2d 749 (1987), cert granted, sub nom Will v Michigan Dept. of State Police, 108 S Ct 1466 (1988) (holding that states are not "persons" under \& 1983).

ss Lincoln County $v$ Luning, 133 US 529 (1890) (counties); Workman v New York City, 179 US 552 (1900) (municipalities); Mount Healthy City School Dist. Bd. of Educ. v Doyle, 429 US 274 (1977) (school boards).

32 The Court distinguishes between a state's political subdivisions (e.g., counties or municipalities), which do not enjoy Eleventh Amendment immunity, and its departmental "arms," which are clothed in such immunity. See, for example, Lake Tahoe Country Estates, Inc. $v$ Tahoe Regional Planning Agency, 440 US 391, 400-02 (1979) (denying immunity to an agency created by interstate compact because its function, structure, and composition was more akin to a subdivision than a departmental arm of the state).

10209 US 123 (1908). See also Osborn $v$ Bank of the United States, 22 US (9 Wheat) $738,850-57$ (1824), and text at notes 339-60.

11 Ex parte Young, 209 US at 160.

42312 US 496 (1941). See also text at notes 98-112.

13 401 US 37 (1971). See also text at notes 91-97.

4415 US 651 (1974). 
vate parties seek[] to impose a liability which must be paid from public funds in the state treasury."45 Moreover, while the Court in Ex parte Young held that a federal court may enjoin a state official from violating the federal constitutional rights of its citizens, in Pennhurst State School \& Hospital v Halderman ${ }^{46}$ the Court held that the Eleventh Amendment prohibited a federal court from enjoining a state official from further violations of state law.

Although a state may expressly consent to suit against it in a federal court, several doctrines operate to subject states to suit in the federal forum even when they have not expressly consented. Congress may, by legislation, abrogate state sovereign immunity from suit in federal courts. In Fitzpatrick v Bitzer, ${ }^{47}$ the Court determined that Congress was empowered to do so under $\S 5$ of the Fourteenth Amendment. ${ }^{48}$ In Fitzpatrick, the Court approved congressional action that created a private right of action for money damages against states that had engaged in employment discrimination in violation of Title VII of the Civil Rights Act. ${ }^{49}$ The Court has left open the question of whether Congress may similarly abrogate a state's Eleventh Amendment immunity under its Article I powers. ${ }^{50}$ Whatever the source of power for such congressional ab-

45 Id at 663. But see Hutto $v$ Finney, 437 US 678 (1978) (affirming award of attorneys' fees pursuant to 42 USC $\S 1988$, to be paid by a state, on the theory that the monetary grant was merely ancillary to the injunction entered by the court).

46 US 89 (1984).

4727 US 445 (1976).

48 "The Congress shall have power to enforce, by appropriate legislation, the provisions of this article." US Const, Amend XIV, § 5. The Fitzpatrick principle was apparently extended to include the Fifteenth Amendment by City of Rome $v$ United States, 446 US 156, 179-80 (1980). The Court has yet to decide whether a federal court private cause of action against a state may be inferred directly from the Fourteenth or Fifteenth Amendments, or any other constitutional provision. See Milliken $v$ Bradley, 433 US 267, 290-91 n 23 (1977). This position may have been implicitly rejected by the Court in Atascadero State Hospital $v$ Scanlon, 473 US 234 (1985), since it is an easy conceptual move to extend the Court's "unmistakable and unequivocal" congressional abrogation test in Atascadero to the constitutional text. See note 50 and accompanying text.

4942 USC $\S 2000$ et seq (1982). In amending the 1964 Civil Rights Act by the Equal Employment Opportunity Act of 1972, 86 Stat 103, codified at 42 USC 2000e (1982), Congress included "governments" among the employers subject to the Act's prohibitions against discriminatory employment practices and exposed to private employee actions for back pay. See 42 USC $\$ 2000 \mathrm{e}(\mathrm{a}, \mathrm{b})$. This was sufficiently plain language to indicate congressional intent to abrogate Eleventh Amendment immunity. See Fitzpatrick, 427 US at 451-52.

${ }^{\text {so }}$ See County of Oneida $v$ Oneida Indian Nation, 470 US 226, 252 (1985). In Welch $v$ State Dept. of Highways and Public Transp., 107 S Ct 2941 (1987), the Court hinted that congressional power to abrogate state Eleventh Amendment immunity may not be confined to section 5 of the Fourteenth Amendment: "We assume, without deciding or intimating a view of the question, that the authority of Congress to subject unconsenting States to suit in federal court is not confined to $\S 5$ of the Fourteenth Amendment." Id at 2946 (plurality opinion of Powell); and 2957-58 (Scalia concurring in part and concurring in the judgment). 
rogation, Atascadero State Hospital $v$ Scanlon ${ }^{\text {11 }}$ requires that Congress "mak[e] its intention [to abrogate] unmistakably clear in the language of the statute." $\$ 2$ The articulation of this requirement coincided with the downfall of the less stringent "constructive waiver" doctrine that allowed courts to infer state consent to suit."s

Current Eleventh Amendment law is beset by problems. Courts and litigants expend vast amounts of energy in determining whether the state is the real party in interest, whether the relief sought is permissible under Edelman, or whether a statute contains unmistakable and unequivocal evidence of congressional intention to abrogate Eleventh Amendment immunity. ${ }^{54}$ Even more energy will be expended upon debate over the permissible limits, if any, on congressional power to abrogate Eleventh Amendment immunity. While Pennsylvania v Union Gas Co. ${ }^{\mathrm{ss}}$ presents the Supreme Court with a splendid opportunity to resolve this lingering

At least five circuits agree with Justice Powell's quoted assumption: United States $v$ Union Gas Co., 832 F2d 1343 (3d Cir 1987), cert granted sub nom Pennsylvania v Union Gas Co., 108 S Ct 1219 (1988) (Congress may create federal cause of action against an unconsenting state under the Commerce Clause); In re McVey Trucking, Inc., 812 F2d 311 (7th Cir 1987), cert denied, $108 \mathrm{~S} \mathrm{Ct} 227$ (1987) (Congress may create federal cause of action against an unconsenting state to recover preferential transfer in bankruptcy); County of Monroe $v$ Florida, 678 F2d 1124 (2d Cir 1982) (Congress may create federal cause of action against a state under its extradition power); Peel v Florida, $600 \mathrm{~F} 2 \mathrm{~d} 1070$ (5th Cir 1979) (Congress may create federal cause of action against a state under its war powers); Mills Music $v$ Arizona, 591 F2d 1278 (9th Cir 1979) (Congress may create federal cause of action against a state under the Copyright and Patent Clause). Of course, acting pursuant to any of its powers, Congress is free to create a right for the United States to sue a state and state sovereign immunity will pose no obstacle.

s1 473 US 234 (1985).

s2 Id at 242. The Court elaborated on this theme: "Congress must express its intention to abrogate the Eleventh Amendment in unmistakable language in the statute itself. ... A general authorization for suit in federal court is not the kind of unequivocal statutory language sufficient to abrogate the Eleventh Amendment." Id at 243, 246.

${ }^{53}$ See Welch, $107 \mathrm{~S} \mathrm{Ct}$ at 2948 (plurality opinion of Powell), and 2958 (Scalia concurring in part and concurring in the judgment). Constructive waiver originated in Parden $v$ Terminal Ry., 377 US 184 (1964), in which the Court held that a state's employment of persons in activities subject to the Federal Employer's Liability Act, 45 USC \& 51 et seq, operated as a "constructive waiver" by the state of its Eleventh Amendment immunity. The Welch Court concluded that the constructive waiver doctrine was incompatible with the level of unmistakable, unequivocal congressional intention required by Atascadero. Although the Welch Court expressly overruled Parden, it did not reach the issue of the scope of congressional power over state immunity, and thus it left standing Parden's conclusion that Congress possesses sufficient power under the Commerce Clause to abrogate a state's Eleventh Amendment immunity. See Welch, $107 \mathrm{~S} \mathrm{Ct}$ at 2948 n 8 (plurality opinion), and 2957-58 (Scalia concurring in part and concurring in the judgment).

of For an example of precisely this phenomenon see In re McVey Trucking, Inc., 812 F2d 311 (7th Cir 1987).

ss Cert granted, 108 S Ct 1219 (1988), reported below as, United States $v$ Union Gas Co., 832 F2d 1343 (3d Cir 1987). 
uncertainty, the Court's disposition might very well increase, rather than diminish, the confused state of the Eleventh Amendment. ${ }^{\text {s6 }}$

Most of these problems can be ameliorated if the concept of state sovereign immunity that current doctrine locates within the Eleventh Amendment is treated as part of the residual state sovereignty preserved by the Tenth Amendment. ${ }^{57}$ Although a full discussion of this thesis is deferred until sections IV and V, it is important to survey briefly the current state of Tenth Amendment jurisprudence before exploring the history of the Eleventh Amendment.

\section{B. The Tenth Amendment}

Since the Supreme Court's 1985 decision in Garcia $v$ San Antonio Metropolitan Transit Authority ${ }^{58}$ it is tempting to treat the Tenth Amendment as having been consigned to the nether world of non-justiciability. The Garcia decision overruled National League of Cities $v$ Usery, ${ }^{59}$ a case that had held that the Commerce Clause ${ }^{60}$ did not empower Congress to enforce the minimum wage and overtime provisions of the Fair Labor Standards Act ${ }^{61}$ against the states "in areas of traditional governmental functions." ${ }^{22}$ In Garcia, five justices joined in a majority opinion that, in effect, concluded that if states desire to preserve any aspect of their sovereignty within the federal system they must look to Congress, and not to the courts. ${ }^{63}$ The Court accepted the Tenth

${ }^{56}$ See notes $413-19$ and accompanying text.

${ }^{87}$ See text at notes 399-406. Not every problem is eliminated. The issue of ascertaining congressional intent to abrogate Tenth Amendment state sovereign immunity might well remain, for the Atascadero Court's requirement that Congress make its intent "unmistakably clear in the language of the statute" would presumably survive transfer of state sovereign immunity from the Eleventh to the Tenth Amendment. See Atascadero, 473 US at 242.

${ }^{58} 469$ US 528 (1985).

s9 426 US 833 (1976).

Bo US Const, Art I, § 8.

BI The specific statute in question was the Fair Labor Standards Act Amendments of 1974, § 6(a), Pub L No 93-259, 88 Stat 58, amending 29 USC $\S 203(e)$ (1970).

${ }_{62}$ National League of Cities, 426 US at 852.

63 "[T]he principal means chosen by the Framers to ensure the role of the States in the federal system lies in the structure of the Federal Government itself." Garcia, 469 US at 550. "[T] $T$ he Framers chose to rely on a federal system in which special restraints on federal power over the States inhered principally in the workings of the National Government itself, rather than in discrete limitations on objects of federal authority. State sovereign interests, then, are more properly protected by procedural safeguards inherent in the structure of the federal system than by judicially created limitations on federal power." Id at 552. The Court has expanded upon this view in South Carolina v Baker, $108 \mathrm{~S} \mathrm{Ct} 1355$ (1988), characterizing Garcia as holding that Tenth Amendment "limits are structural, not substantive-i.e., 
Amendment as an affirmation of state sovereign authority but "the fact that the States remain sovereign as to all powers not vested in Congress or denied them by the Constitution offers no guidance about where the frontier between state and federal power lies. In short, we have no license to employ freestanding conceptions of state sovereignty when measuring congressional authority under the Commerce Clause." $"$ "4

If the frontier is to be found anywhere, it is to be found on the outer edges of congressional power under the Constitution:

[T] he sovereignty of the States is limited by the Constitution itself. A variety of sovereign powers ... are withdrawn from the States by Article I, $\S 10$. Section 8 of the same Article works an equally sharp contraction of state sovereignty by authorizing Congress to exercise a wide range of legislative powers and (in conjunction with the Supremacy Clause of Article VI) to displace contrary state legislation. ${ }^{65}$

Several themes flow from Garcia's restatement of these familiar principles. The concept of state sovereignty is implicitly recognized as predating constitutional union. The Tenth Amendment is treated as a statement that states possess residual sovereign powers, but the extent of those sovereign powers is measured by the area left for state action after Congress has validly exercised its delegated powers. ${ }^{68}$ This approach to the Tenth Amendment assumes that the task is simply to describe the limits of federal power; whatever remains is state sovereignty. An alternative approach is to start with state power: all powers are reserved to the states except those prohibited and those delegated. Thus, unless Congress acts pursuant to a power that is comfortably within the zone of authority delegated to it, Congress has usurped authority belonging to the states. Though the end result is theoretically identical, the manner in which the inquiry is formulated suggests a

that States must find their protection from congressional regulation through the national political process, not through judicially defined spheres of unregulable state activity." Id at 1360.

64 Garcia, 469 US at 550.

os Id at 548 .

6s Professor Berns contends that the Tenth Amendment, by itself, "is not and cannot provide a rule of law of the Constitution," and hence its legal meaning is supplied only in reference to the limitations on valid congressional power. Walter Berns, The Meaning of the Tenth Amendment, in Robert A. Goldwin, ed, A Nation of States 139, 146, 158-61 (Rand McNally, 2d ed 1974). But see Raoul Berger, Federalism: The Founders' Design 84 (U Okla, 1987) ("Why does not the express reservation of undelegated powers equally furnish the 'terms' of constitutional adjudication?"). 
great deal about the likely conclusions concerning distribution of state and federal power. ${ }^{67}$

The Court's decision in National League of Cities was a shortlived effort to find in the Tenth Amendment a principle of state sovereignty that insulated some state activities from congressional regulation that would otherwise be valid as applied to private parties. The abandonment of this enterprise in Garcia signals the Court's unwillingness to stake out a boundary to congressional power as applied to the states any more restrictive than that applicable to private entities. The conventional reading of Garcia is that the "Court abdicate[d] tenth amendment questions." it may have done so formally, in effect the Court simply transferred attention to Article I in the judicial interpretive task of surveying the federal-state frontier. Generous readings of congressional power push the federal boundary well into state territory; revisionist notions of congressional power promise a reversal of this trend. ${ }^{69} \mathrm{It}$ is on this turf that many future battles will be fought, but not the entire war.

There remain a number of "freestanding" conceptions surrounding "federalism" that have at their core notions of state sovereignty very much like the sovereignty principles abandoned to the political arena in Garcia. If these principles were to be thought of as Tenth Amendment guarantees, ${ }^{70}$ or simply as rooted in Tenth Amendment principles of residual sovereignty, rather than seemingly unconnected and disparate doctrines, courts would be required, or at least encouraged, to rethink the permissible limits of

${ }^{67}$ A good example of this approach is Gibbons $v$ Ogden, 22 US (9 Wheat) 1 (1824). Chief Justice Marshall observed that "[c]ommerce among the states" does not "comprehend that commerce, which is completely internal, which is carried on between man and man in a state, or between different parts of the same state.... [T] he enumeration of the particular classes of commerce to which the [commerce clause] power was to be extended ... presupposes something not enumerated; and that something ... must be the exclusively internal commerce of a state." Id at 194-95. Thus, when Marshall correctly observed that "the sovereignty of congress, though limited to specified objects, is plenary as to those objects" (id at 197), it is evident that his starting point was the reserved powers of the states to regulate their internal commerce.

${ }^{68}$ A. E. Dick Howard, Garcia and the Values of Federalism: On the Need for a Recurrence to Fundamental Principles, $19 \mathrm{Ga} \mathrm{L} \mathrm{Rev} \mathrm{789,} 793$ (1985).

${ }^{69}$ See, for example, Richard A. Epstein, The Proper Scope of the Commerce Power, 73 Va L Rev 1387 (1987); Berger, Founders' Design (cited in note 66).

${ }^{70}$ The Court has begun to provide verbal, if not substantive, recognition of this point: "We use 'the Tenth Amendment' to encompass any implied constitutional limitation on Congress' authority to regulate state activities, whether grounded in the Tenth Amendment itself or in principles of federalism derived generally from the Constitution." South Carolina v Baker, 108 S Ct 1355, 1360 n 4 (1988). 
congressional action and state sovereignty. Moreover, to the extent these freestanding sovereignty notions are treated as aspects of a state's residual sovereignty preserved by the Tenth Amendment, it becomes apparent that, despite protestations to the contrary in Garcia, the Court is constantly engaged in a judicial patrol of the frontier between federal and state sovereignty. A brief examination of some of these sovereignty principles may serve to clarify the point.

These principles may best be understood in terms of the broad rationales that seem to unite disparate sovereignty doctrines. First, under both the Erie doctrine and the adequate and independent state grounds principle, the Court has relied on the premise that a jurisdictional grant does not automatically confer substantive lawmaking authority. Thus, the Court has recognized the principle of state sovereignty by its deference to state law as the dispositive rule of decision in these cases. Second, even when a substantive issue of federal law is clearly present in a case and no dispositive issue of state law is present, the Court has refrained from exercising the full force of federal question jurisdiction in order to accommodate perceived state sovereignty interests. This pattern is seen most readily in such doctrines as abstention, exhaustion, and the statutory commands of the Anti-Injunction Act. Finally, in determining the scope of the Article I prohibitions upon state power, the Court has fashioned tests that defer to state interests so long as federal authority is not thereby impaired. The Court's Compact Clause jurisprudence is perhaps the clearest example.

\section{Adequate and independent state grounds.}

The United States Supreme Court has "from the time of its foundation ... adhered to the principle that it will not review judgments of state courts that rest on adequate and independent state grounds." This doctrine has proved to be a "vexing issue"72 as the Supreme Court has struggled with the problem of deciding whether a state ground has been passed upon and, if so, whether that ground is sufficiently adequate and independent of federal claims present in the litigation to support the state court's deci-

71 Herb $v$ Pitcairn, 324 US 117, 125 (1945). This proposition follows from the fact that the Supreme Court's statutorily created appellate jurisdiction of state court judgments has always been limited to review of federal questions decided by the state courts. See 28 USC $\S$ 1257 (1948); see also note 76.

${ }^{72}$ Michigan v Long, 463 US 1032, 1038 (1983). 
sion. ${ }^{73}$ Where federal claims are present, the adequate and independent state grounds doctrine can be claimed to be constitutionally required, ${ }^{74}$ compelled by statute, ${ }^{78}$ or merely prudential. ${ }^{76}$

${ }^{73}$ See generally Thomas E. Baker, The Ambiguous Independent and Adequate State Ground in Criminal Cases: Federalism Along a Möbius Strip, 19 Ga L Rev 799 (1985); Alfred Hill, The Inadequate State Ground, 65 Colum L Rev 943 (1965); Tribe, American Constitutional Law at 162-73 (cited in note 2).

74 The argument begins with the proposition that where a state court judgment rests on adequate and independent state grounds the federal courts are deprived of jurisdiction of all claims in the case, including the federal ones. If this is so, it must be because of the respect due one sovereign by another. Though " $[t]$ he jurisdiction of the nation . . . is susceptible of no limitation, not imposed by itself," The Schooner Exchange $v M^{\prime} F a d d o n, 11$ US (7 Cranch) 116, 136 (1812), that self-imposed limitation can be read into the principle of residual state sovereignty embodied in the Tenth Amendment. This idea derives some support from Murdock v Memphis, 87 US (20 Wall) 590 (1874), in which the Court expressed doubt about the power of Congress to enable the federal courts to review and decide issues of state law independently of the state courts. Id at 626,633 . Professor Tribe contends that Murdock bars the Court from "reviewing federal issues in those cases which also contain state issues dispositive of the case." Tribe, American Constitutional Law at 163 (cited in note 2) (emphasis in original). This is because Murdock has a "constitutional resonance" that prevents the Congress from authorizing the Supreme Court to decide state law issues. Id at 380. See also Henry M. Hart, Jr., The Relations Between State and Federal Law, 54 Colum L Rev 489, 503 (1954).

${ }^{75}$ Congress, of course, has authority under the "exceptions and regulations" Clause to restrict the Supreme Court's appellate jurisdiction. US Const, Art III, § 2, cl 2. See also Ex parte McCardle, 74 US (7 Wall) 506 (1868) (recognizing at least a limited power for Congress to withdraw the appellate jurisdiction of the Supreme Court in appeals from lower federal courts). From the Judiciary Act of 1789 on, the Supreme Court's appellate jurisdiction over state courts has been limited to cases posing certain federal issues. See Judiciary Act of 1789, ch 20, \& 25, 1 Stat 73, 85-87, codified as amended at 28 USCA § 1257 (Supp 1989). In 1867 Congress removed a proviso in $\S 25$ of the 1789 Act that limited the Court's appellate jurisdiction to the review of federal issues. Act of Feb 5, 1867, ch 28, $\S 2,14$ Stat 385, 386-87. In Murdock v Memphis, 87 US (20 Wall) 590 (1874), the Court concluded that Congress had not intended to confer jurisdiction over state law matters since the repeal of the 1789 proviso was not a sufficiently clear statement of such intent. Id at 619,630 . Congress has never responded by an explicit grant of such jurisdiction, apparently content that its statutory directives are satisfied by the Court's employment of the adequate and independent state grounds doctrine. Murdock is commonly regarded as a germinal source of the adequate and independent state grounds doctrine, though that reading of Murdock has recently been criticized. See Martha A. Field, Sources of Law: The Scope of Federal Common Law, 99 Harv L Rev 881, 920-22 \& nn 180-81 (1986); Richard A. Matasar and Gregory S. Bruch, Procedural Common Law, Federal Jurisdictional Policy, and Abandonment of the Adequate and Independent State Grounds Doctrine, 86 Colum L Rev 1291, 1317-22 (1986).

${ }^{76}$ Ever since Martin v Hunter's Lessee, 14 US (1 Wheat) 304 (1816), the Supreme Court has possessed power to review state court judgments of federal statutory or constitutional law. As a theoretical proposition, a case containing a federal issue confers federal jurisdiction; the adequate and independent state grounds doctrine is not a jurisdictional bar but is a judicial refusal to exercise its jurisdiction. Matasar and Bruch contend that Martin also "broadly authorizes federal review of state law matters." Matasar \& Bruch, 86 Colum L Rev at 1297 (cited in note 75), (emphasis in original). More precisely, their contention is that, in deciding the case prior to Martin, the Court was compelled to pass upon the validity of Hunter's title under Virginia law. Fairfax's Devisee v Hunter's Lessee, 11 US (7 Cranch) 603 (1813); see also Matasar \& Bruch, 86 Colum L Rev at 1297-98. In fact, the ultimate title 
Because Congress has never conferred upon the Supreme Court the power to review state court determinations of state law in federal question cases, ${ }^{77}$ the issue of the constitutional validity of federal judicial review of purely state claims has never squarely arisen. ${ }^{78}$ If Congress did so act, the Court would have to decide whether Congress can deprive the states of their lawmaking autonomy in order to effectuate the jurisdiction of the Supreme Court. The conclusion of two esteemed commentators that such congressional action would violate the Tenth Amendment and "related principles of state autonomy" surely indicates a belief that the Tenth Amendment, even after Garcia, possesses some normative core of its own. ${ }^{80}$ It is within that core-which includes the "tacit

determination hinged on federal treaty law issues. Martin, 14 US (1 Wheat) at 358. Inquiry into the state of title under Virginia law was simply a "preliminary inquiry" undertaken in order to "construe the treaty in reference to that title." Id. See also Smith v Maryland, 10 US (6 Cranch) 286, 305-07 (1810) (similar inquiry made into Maryland law in order to determine treaty issues). Matasar and Bruch also cite Osborn v Bank of the United States, 22 US (9 Wheat) 738 (1824), in support of the proposition that the federal courts may take jurisdiction of a case if it contains any federal issue and thereafter decide both state and federal issues presented. 86 Colum L Rev at 1299-1300 (cited in note 75). But this reading of Osborn is overbroad, for Osborn does not purport to hold that the federal courts may decide state law independently and thereafter bind the states through the Supremacy Clause. While the federal courts might have wielded such power under the diversity clause prior to Erie R.R. $v$ Tompkins, 304 US 64 (1938), they have never had such power in federal question cases.

${ }^{77}$ See note 75. If federal courts possessed the power of appellate review of pure state law issues, the exercise of that power would result in the creation of a federal common law that would displace state law. The alternative is the untidy phenomenon of a federal court altering settled interpretations of state law under the pretense of acting as a state's final court of appeal. For example, in a case posing the issue of the legal effect of a plaintiff's negligence under California law, a federal court might conclude that California's rule of comparative negligence is displaced by a federal rule of contributory negligence, rather than asserting the power to revise settled California law by substituting contributory for comparative negligence as a matter of California law. Although the former notion bears some similarities to the doctrine of Clearfield Trust Co. $v$ United States, 318 US 363 (1943), which fashioned a post-Erie federal common law with respect to commercial paper issued by the United States, either idea carries in it the germ of a wholesale destruction of a state's independent law making power. This potential for elimination of state sovereignty thus strongly suggests that federal review of pure state law issues does not comport with the residual state sovereignty preserved by the Tenth Amendment. Professor Merritt has argued that, unless the states "retain sufficient autonomy to establish and maintain their own forms of government" they are deprived of the federal government's pledge to "guarantee to every State in this Union a Republican Form of Government." US Const, Art IV, § 4. See Deborah Jones Merritt, The Guarantee Clause and State Autonomy: Federalism for a Third Century, 88 Colum L Rev 1, 2 (1988).

${ }^{78}$ But see discussion of Martin $v$ Hunter's Lessee, 14 US (1 Wheat) 304 (1816) and Fairfax's Devisee v Hunter's Lessee, 11 US (7 Cranch) 603 (1813), in note 76.

79 Tribe, American Constitutional Law at 163 (cited in note 2); Field, 99 Harv L Rev at 919 n 174 (cited in note 75 ).

so This normative core of state sovereignty can also be derived from the delegated and 
postulates"81 of the Constitution with respect to state sovereignty - that the adequate and independent state grounds doctrine resides.

\section{The Erie doctrine.}

The familiar rule of Erie Railroad Co. $v$ Tompkins ${ }^{82}$ partakes heavily of the Tenth Amendment. Federal courts sitting in diversity are bound by state decisional law to the same extent as state courts, and may not infer from the grant of diversity jurisdiction itself a power to contravene state precedents by fashioning a federal common law. ${ }^{83}$ Even in federal question cases involving state law issues, Erie commands that state decisional law be observed. ${ }^{84}$ When considered with Murdock $v$ Memphis ${ }^{85}$ which holds that the Supreme Court will not review issues of state law, ${ }^{86}$ the Erie doctrine preserves the integrity of state law from federal judicial erosion. While the long history of a general common law as the rule of decision in federal courts prior to Erie prevents any flat assertion that the Tenth Amendment compels the holding in Erie, the modern entrenchment of Erie doctrine is further evidence that the "tacit postulates" of state sovereignty continue to prosper.

\section{Abstention.}

Although the federal courts have, since Marbury $v$ Madison, ${ }^{87}$ recognized their "virtually unflagging obligation . . . to exercise the jurisdiction given them"8s the Supreme Court has fashioned several abstention doctrines "to promote the integrity of state law and respect the autonomy of state judicial officers." erally agreed that abstention doctrines are not constitutionally required, ${ }^{80}$ they nonetheless derive considerable support from the

limited nature of the powers given Congress under Article I. The result is the same as if the Tenth Amendment were read to impose the limits.

81 Nevada $v$ Hall, 440 US 410,433 (1979) (Rehnquist dissenting).

32 US 64 (1938).

8s For a restatement of this familiar principle, in the context of a much larger work, see Field, 99 Harv L Rev at 915-27 (cited in note 75).

84 Id at $912 \mathrm{n} 141$.

ss 87 US (20 Wall) 590 (1874).

${ }^{86}$ See note 75.

87 5 US (1 Cranch) 137 (1803).

${ }^{83}$ Colorado River Water Conservation Dist. $v$ United States, 424 US 800, 817 (1976).

89 Tribe, American Constitutional Law at 196 (cited in note 2).

so See, for example, Matasar \& Bruch, 86 Colum L Rev at 1337-38 (cited in note 75) (abstention is "founded solely on judicial policymaking"); Michael Wells, Why Professor Redish is Wrong About Abstention, $19 \mathrm{Ga} \mathrm{L} \mathrm{Rev} 1097$ (1985) (abstention is a federal com- 
"tacit postulates" of state sovereignty that pervade the Constitution and are most explicitly recognized in the Tenth Amendment.

In Younger $v$ Harris, ${ }^{91}$ the Supreme Court held that principles of "comity and federalism" prevented the federal courts from enjoining state criminal prosecutions. That doctrine has been extended to actions seeking declaratory relief concerning criminal liability ${ }^{92}$ and, most recently, to state civil proceedings. ${ }^{93}$ Although the Court makes no claim that abstention is constitutionally required, its discussion of the applicable principles has proceeded from constitutional norms. In Younger itself the Court emphasized that "the entire country is made up of a Union of separate state governments ... [and] the National Government will fare best if the States and their institutions are left free to perform their separate functions in their separate ways."94 Similarly, later courts have described Younger as resulting from a desire to avoid the "unseemly failure to give effect to the principle that state courts have the solemn responsibility, equally with the federal courts 'to guard, enforce, and protect every right granted or secured by the

mon law doctrine). See also Martin H. Redish, Federal Jurisdiction: Tensions in the Allocation of Judicial Power 233-321 (Michie, 1980); Martin H. Redish, Abstention, Separation of Powers, and the Limits of the Judicial Function, 94 Yale L J 71 (1984) (abstention violates separation of powers).

21401 US 37 (1971)

${ }^{22}$ Samuels v Mackell, 401 US 66, 69-74 (1971).

os It is not clear that Younger applies to all civil litigation. The Younger doctrine was first extended to civil proceedings in Huffman v Pursue, Ltd., 420 US 592 (1975), but in Juidice $v$ Vail, 430 US 327 (1977), the Court indicated that Younger policies are fully applicable to noncriminal judicial proceedings when important state interests are involved, id at 333-34, and saved "for another day" the broader question of whether Younger applies to all civil proceedings. Id at $336 \mathrm{n} 13$. While the Court has still not expressly answered the question reserved in Juidice, it has implicitly done so in Pennzoil Co. $v$ Texaco, Inc., $107 \mathrm{~S} \mathrm{Ct}$ 1519 (1987) (extending Younger to judgment lien and appeal bond requirements in private state civil actions). Justice Blackmun thought the reasoning of the Pennzoil majority threatened to expand Younger to apply "whenever any State proceeding is ongoing, no matter how attenuated the State's interests ....." Id at 1534 (Blackmun concurring in judgment). The Court's decision in Pennzoil thus does what Justice Brennan thought the Juidice decision had done sub rosa. Juidice, 430 US at $345 n *$ (Brennan dissenting) (describing the Juidice reservation for another day as a "tongue in cheek ... signal that merely the formal announcement [of Younger's application to all civil proceedings] is being postponed").

or Younger, 401 US at 44. Following the Pennzoil Court's extension of Younger deeply into the civil arena, see note 93 , "it is certainly clear ... that the most basic underpinning of the Younger doctrine is not any special equity concept but, rather a federalism-based notion of comity." Tribe, American Constitutional Law at 203-04, n 9 (cited in note 2). (emphasis in original). See also Ann Althouse, How to Build a Separate Sphere: Federal Courts and State Power, 100 Harv L Rev 1485, 1488-89, 1531-34 (1987) (at the core of Younger doctrine is a concern for protecting role of state courts as independent adjudicators of state and federal constitutional issues). 
Constitution of the United States." "95 The Supremacy Clause both imposes this responsibility and limits the discretion of the sovereign state courts: violations of federally protected rights are susceptible to correction in the federal courts. ${ }^{96}$ Thus, while Younger abstention is framed in the rhetoric of discretion and prudence, it has roots in two inextricably linked constitutional guarantees: residual state sovereignty and supremacy of federal law. ${ }^{97}$ The Younger doctrine recognizes the state courts' residual sovereignty by permitting them to complete their own judicial proceedings without federal intrusion and recognizes the supremacy of federal law both by reminding the states of their duty to observe and enforce that law and by permitting collateral review of state court judgments in the federal courts.

Similar reasoning informs the Burford ${ }^{98}$ and Pullman ${ }^{99}$ abstention doctrines. The Burford doctrine represents the prudential judgment of the Court that state regulatory schemes involving issues of overriding state concern should be left to the state courts. ${ }^{100}$ Implicit in this doctrine is the view that the states' residual sovereignty ought to be respected. ${ }^{101}$ Indeed, one of the

${ }^{25}$ Steffel $v$ Thompson, 415 US 452, 460-61 (1974), quoting Robb v Connolly, 111 US 624, 637 (1884).

${ }^{96}$ Certiorari to the United States Supreme Court and collateral review via habeas corpus are the principal avenues for such correction. See 28 USC $\S 1257,2241,2254$.

${ }^{97}$ These same principles inform the Anti-Injunction Statute, 28 USC § 2283 (1982). See text at notes $113-20$.

${ }^{98}$ Burford v Sun Oil Co., 319 US 315, 318 (1943) (federal courts should refrain from exercising jurisdiction in order to avoid needless conflict with the administration by a state of its own affairs). See also Kaiser Steel Corp. v W.S. Ranch Co., 391 US 593 (1968); United Gas Pipe Line Co. v Ideal Cement Co., 369 US 134 (1962); Alabama Pub. Serv. Comm'n.v Southern Ry. Co., 341 US 341 (1951).

${ }^{99}$ Railroad Comm. of Texas v Pullman Co., 312 US 496 (1941) (federal courts should refrain from exercising jurisdiction if the case presents an unsettled issue of state law, the resolution of which might avoid a federal constitutional question).

${ }^{100}$ In Burford, Texas had created an administrative system to review decisions of the Texas Railroad Commission, which regulates Texas' important oil and gas industry. The administrative scheme was designed to achieve uniformity and to effectuate the substantive policies of Texas. The Court concluded that abstention from consideration of Sun Oil's challenge to a licensing order of the Railroad Commission was necessary in order to avoid undermining the state's substantive and procedural policies embedded in the administrative scheme. Burford, 319 US at 325-34.

${ }^{101}$ The Supreme Court has since stated that Burford abstention applies whenever federal review of a state question "would be disruptive of state efforts to establish a coherent policy with respect to a matter of substantial public concern." Colorado River Water Cons. Dist. $v$ United States, 424 US 800, 814 (1976). While this appears to be an acknowledgement of residual state sovereignty, some commentators believe that the rationale underlying Burford is not clear. See Wells, $19 \mathrm{Ga} \mathrm{L} \mathrm{Rev} \mathrm{at} \mathrm{1115-18} \mathrm{(cited} \mathrm{in} \mathrm{note} \mathrm{90);} \mathrm{Comment,} \mathrm{Ab-}$ stention by Federal Courts in Suits Challenging State Administrative Decisions: The Scope of the Burford Doctrine, 46 U Chi L Rev 971 (1979). 
variants upon the Burford doctrine, Thibodaux ${ }^{102}$ abstention, applies to cases that present "difficult questions of state law bearing on policy problems of substantial public import whose importance transcends the result in the case then at bar."103 In other words, the federal courts have no business making important state policies by deciding issues of state law. If this is not a recognition of residual state sovereignty, the principle simply does not exist.

Pullman abstention is a doctrine by which federal courts defer to the state courts by permitting them to solve on their own unsettled issues of state law, rather than exercising federal jurisdiction to determine the case on federal constitutional grounds. Pullman is perhaps the most deferential doctrine, for it counsels abstention even when there is no assurance that the state courts will act to decide the case on state grounds. ${ }^{104}$ It requires that "when a federal constitutional claim is premised on an unsettled question of state law, the federal court should stay its hand in order to provide the state courts an opportunity to settle the underlying state law question and thus avoid the possibility of unnecessarily deciding a constitutional question." 105 Its purpose is to avoid interference with state courts in their role as "the principal expositors of state law"106 by channeling the resolution of state issues to the state courts and reserving to the federal courts the unavoidable federal claims. ${ }^{107}$ While federal courts exercising Pullman abstention generally retain jurisdiction by staying the federal action pending state law clarification, ${ }^{108}$ and while the Court has "repeatedly

102 Louisiana Power \& Light Co. v Thibodaux, 360 US 25 (1959).

${ }^{103}$ Colorado River, 424 US at 814.

104 Of course, if the case is decided on federal grounds, or on an ambiguous mixture of federal and state grounds, the Supreme Court may exercise jurisdiction on certiorari. Michigan $v$ Long, 463 US 1032, 1037-42 (1983). See also notes and text at notes 71-81.

${ }^{105}$ Harris County Comm'rs Court v Moore, 420 US 77, 83 (1975) (emphasis added). Pullman abstention only applies when a constitutional issue is posed; the presence of a federal statutory issue is not enough. Propper $v$ Clark, 337 US 472, 490 (1949). The definitive treatment of Pullman abstention is Martha A. Field, Abstention in Constitutional Cases: The Scope of the Pullman Abstention Doctrine, $122 \mathrm{U} \mathrm{Pa} \mathrm{L} \mathrm{Rev} 1071$ (1974).

${ }^{106}$ Moore v Sims, 442 US 415, 429 (1979).

${ }_{107}$ Pullman abstention may also seem to borrow from Justice Brandeis's explication of the devices the Court has used to avoid deciding constitutional issues. See Ashwander $v$ Tennessee Valley Authority, 297 US 288, 341 (1936) (Brandeis concurring). A crucial difference may be seen by supposing a case where the only federal issue posed amidst a host of state law issues is one concerning the Constitution. If a federal court were to ignore the Pullman doctrine and exercise its jurisdiction, but then apply the Ashwander doctrine to avoid reaching the constitutional issue, Erie-type federalism problems would be raised since a federal court might be tempted to refashion state law. Pullman abstention thus plays a key role in avoiding such federal-state conflict.

${ }^{108}$ Harris County, 420 US at 83. A litigant cannot be compelled to submit her federal 
warned" the federal courts that Pullman abstention should only be invoked in "special circumstances," 109 the rationale underlying the Pullman doctrine partakes heavily of the "tacit postulates" of residual state sovereignty.

That the abstention doctrines are rooted in conceptions of state sovereignty, whether expressed as comity or as a constitutional right reserved to the states through the Tenth Amendment, can be seen even more clearly in what the Supreme Court considers to be outside the abstention pigeonhole. Commentators speak of Colorado River abstention" 110 as a doctrine that "involves parallel actions filed in both state and federal courts. . . .[and] authorizes federal courts to decline their jurisdiction to foster sound management of cases." 111 Yet, the Court does not regard the Colorado River rule as a true abstention doctrine because it is not founded upon "considerations of state-federal comity or . . . avoidance of constitutional decisions." 112 If this foundation is the sine qua non of abstention, then abstention ranks in the first order of the Constitution's "tacit postulates" of residual state sovereignty. Moreover, given the constitutional obligation of federal courts to exercise their jurisdiction, their failure to do so can best be explained by positing a judicial recognition that, in a dual sovereignty system, each sovereign must be the master of its own laws. Like a mountain range that has been thrust upward by the collision of tectonic plates, abstention is a doctrine that has grown up by the collision of constitutional principles. The discretionary nature of abstention does not reflect a lack of constitutional foundation so much as it illustrates the continually shifting, and hard-tolocate, frontier of federal and state sovereignty. The Court has been able to keep the sentry post manned here; there is no reason to think that its abandonment of the Garcia post presages a general retirement from the frontier.

\section{Anti-Injunction Act.}

A concept related to abstention is to be found in the Anti-

claims to the state court for final adjudication. See England $v$ Louisiana State Bd. of Medical Examiners, 375 US 411, 415-17 (1964).

${ }^{108}$ Harris County, 420 US at 83.

${ }_{110}$ Colorado River Water Cons. Dist. v United States, 424 US 800 (1976). See, for example, Matasar \& Bruch, 86 Colum L Rev at 1337 n 232, 1342 (cited in note 75).

111 Matasar \& Bruch, 86 Colum L Rev at 1342 (cited in note 75).

${ }_{112}$ Moses H. Cone Memorial Hosp. v Mercury Construction Corp., 460 US 1, 14-15 (1983). 
Injunction Act, ${ }^{113}$ which prohibits federal courts from enjoining state court proceedings "except as expressly authorized by Act of Congress, or where necessary in aid of its jurisdiction, or to protect or effectuate its judgments."114 It has been a continuous limitation upon federal invasion of state sovereignty since its enactment as part of the Judiciary Act of $1793 .{ }^{115}$ While its express terms presume congressional authority to vest federal courts with the power to invade state judicial sovereignty, its existence since the formation of the federal union is a powerful signal of a fundamental limit upon federal authority. The Court's recognition of that limit can be seen most plainly in the interaction between the Anti-Injunction Act and the Younger doctrine. For example, a federal court in a $\S 1983$ action may enjoin state court proceedings because $\S 1983$ is deemed to be sufficient "express authorization" by Congress to escape the statutory bar of the Anti-Injunction Act. ${ }^{116}$ Nevertheless, the mere removal of the statutory bar does not "qualify in any way the principles of equity, comity and federalism that must restrain a federal court when asked to enjoin a state proceeding."117 Thus, the Younger doctrine seems both to compel a more stringent prohibition than the Anti-Injunction Act, and to derive its compulsive force from mandatory principles of "equity, comity and federalism." If state sovereignty principles possess such clout, it is difficult to accept that the Tenth Amendment, the clearest textual expression of these values, is no more than a descriptive and passive placeholder. ${ }^{118}$

This conclusion is not rooted solely in the Younger doctrine,

11328 USC § 2283 (1982).

114 Id.

11 Act of March 2, 1793, § 5, I Stat at 334, 335 (1793) ("a writ of injunction [shall not] be granted to stay proceedings in any court of a state"). This provision has been codified as Rev Stat $\$ 720$ (1878); Judicial Code $\S 265$ (1911); 28 USC $\$ 379$ (1940); and finally at 28 USC § 2283 (1982).

11 Mitchum v Foster, 407 US 225 (1972).

${ }^{117}$ Id at 243 (emphasis added). This principle was emphatically reaffirmed in Pennzoil Co. $v$ Texaco, Inc., $107 \mathrm{~S}$ Ct 1519, 1525-26 (1987).

118 The intersection of the Anti-Injunction Act and Younger principles casts doubt on the glib observation in United States $v$ Darby, 312 US 100 (1941), that the Tenth Amendment is a "truism that all is retained which has not been surrendered." Id at 124. If a federal court in a 42 USC $\S 1983$ action has the power to enjoin a state court (because Congress has authorized it to do so) but it may not exercise that power due to principles of "equity, comity and federalism," it appears that something exists that vetoes congressional attempts to exercise its powers. That "something" may be a recognition that Congress is acting beyond its delegated powers, an exercise of judicial prudence, or a recognition that retained state sovereignty occupies a sphere that, in some instances, trumps congressional power. 
however. The rules embodied in the Anti-Injunction Act may well be constitutionally required.119 If the boundaries of state sovereignty, preserved by the Tenth Amendment, are defined by the limits of the powers entrusted to the federal government, ${ }^{120}$ the federal courts must possess the power to intrude upon state jurisdiction when Congress so directs through a valid exercise of its legislative powers, or when necessary to preserve the valid jurisdictional limits of the federal courts. But surely the federal courts are not able to restrain state courts if the Congress directs them to do so pursuant to an illegitimate claim of authority, or if the federal courts themselves act outside their jurisdictional grant. From this perspective, the Anti-Injunction Act is more than a monument to a customary practice since the nation's beginning; it is another embodiment of the Constitution's tacit postulates of twin sovereignties.

\section{Exhaustion of state administrative remedies.}

Another doctrine related to Tenth Amendment principles is the requirement that plaintiffs contending that a state has violated their constitutional rights must first exhaust their state administrative remedies before seeking relief in the federal courts. ${ }^{121}$ The Supreme Court has justified this rule as necessary to provide the states an opportunity to protect federal constitutional rights through their own systems, to ensure that the litigant's assertions of state misconduct are correct, and to avoid an unnecessary constitutional decision when the states may obviate the claim by their

119 More strictly, part of the Anti-Injunction Act is a canon of statutory construction, which the Court might read into all statutes under Younger-type principles even in the absence of the Act; part of the Act is constitutionally compelled, so that Congress might not be able to order the federal courts to enjoin state proceedings merely to effectuate the federal courts' diversity jurisdiction.

120 Of course, the limits of state sovereignty are also defined by the prohibitions upon the states contained in the Constitution. US Const, Amend X.

${ }_{121}$ See, for example, Illinois Commerce Comm'n v Thompson, 318 US 675, 686 (1943); First Natl Bank of Greely v Board of County Comm'rs, 264 US 450 (1924). Suits under 42 USC $\S 1983$ are exempt from the requirement. See Patsy $v$ Board of Regents of Florida, 457 US 496 (1982). But see note 118 and accompanying text (abstention applies even to $\S 1983$ actions). In general, there is no requirement that a litigant exhaust state judicial remedies. See Home Tel. \& Tel. Co. $v$ Los Angeles, 227 US 278, 284-86 (1913) (interpreting the Fourteenth Amendment); Monroe v Pape, 365 US 167, 183 (1961) (construing 42 USC § 1983). But see Prentis v Atlantic Coast Line Co., 211 US 210, 229-30 (1908) (litigant must exhaust both state administrative and judicial remedies if the state courts participate in the administrative process); 28 USC $\$ 2254$ (exhaustion of state judicial remedies required for habeas corpus); 28 USC $\S 1341$ (state tax collection issues); 28 USC $\S 1342$ (state utility rate orders). 
own action. ${ }^{122}$ In its frank concern for the role demanded of the states by the Supremacy Clause in preserving federal constitutional rights, the exhaustion requirement echoes one aspect of the Younger rationale. ${ }^{123}$ While the Supremacy Clause obligates the states to enforce the Constitution, residual state sovereignty principles should, and often do, operate to give the state courts and administrative systems the first opportunity to fulfill their obligation. The role of the federal judiciary is only to act as a corrective in cases of state inaction or misconduct.

\section{Compact Clause.}

The Court has also applied Tenth Amendment notions of state sovereignty, while not openly acknowledging its debt, in interpreting the Compact Clause, which provides that "[n]o state shall, without the consent of Congress, ... . enter into any Agreement or Compact with another State. ..."124 The Clause has been interpreted to require congressional consent only for those compacts that infringe upon "the political power or influence" of a state or that encroach "upon the full and free exercise of Federal authority."125 Thus, for example, reciprocal tax statutes are deemed beyond the requirements of the Compact Clause because they neither compromise the state's authority nor intrude upon federal authority. ${ }^{\mathbf{1 2 6}}$

Since it prohibits the states from exercising the full range of their authority, the Compact Clause forms part of the frontier of the states' residual sovereignty. In charting this segment of the frontier, the Court has chosen a test that sensibly defers to state interests so long as federal authority is not thereby impaired. If the shaping influence of residual state sovereignty was not at work here, there would be no need for a test that gives ample latitude to states. A rigid textualist, oblivious to state sovereignty themes,

122 See, for example, Prentis v Atlantic Coast Line Co., 211 US 210, 230 (1908).

123 See text at notes 95-97.

124 US Const, Art I, \& 10, cl 3.

125 Virginia $v$ Tennessee, 148 US 503, 520 (1893).

${ }^{128}$ See United States Steel Corp. v Multistate Tax Commission, 434 US 452 (1978), in which 21 states created a joint commission to coordinate state taxation of businesses operating in multiple states. Although the tax compact increased the power of the states relative to the corporate taxpayer, the Court found that comparison irrelevant, noting that the test was "whether the Compact enhances state power quoad the National Government." Id at 473. See also Bode v Barrett, 344 US 583, 586 (1953) (Court upholds the validity of an Illinois state tax challenged under the Compact Clause. The tax exempted non-residents if their home states reciprocated and granted like exemptions to Illinois residents). 
might simply declare that the Compact Clause requires congressional approval of every interstate agreement, no matter what its impact may be on the apportionment of sovereign authority between the states and the national government. The Court's rejection of this approach is another sure indication of the vitality of state sovereignty and the Tenth Amendment.

A curious anomaly thus emerges in the current law of the Tenth Amendment. The state-federal frontier formed by Tenth Amendment jurisdictional doctrines is willingly policed by the Court as it relates to Article III. But where the border is delineated by the extent of congressional legislative power, the Court is simply not willing to find any independent limiting force in the Tenth Amendment itself, ${ }^{127}$ nor does it appear willing to reconsider the limits of congressional authority (particularly under the Commerce Clause) ${ }^{128}$ in light of the Constitution's explicit and tacit commands to preserve state sovereignty.

Current Tenth Amendment doctrine may be classified within the mainstream of the "cooperative federalism" doctrine decried by Professor Corwin. ${ }^{129}$ While cooperative federalists posit a system embodying a sharing of functions between the state and federal governments, the system in reality is one of ever expanding federal authority at the expense of the states. ${ }^{130}$ The implicit adoption of cooperative federalism by a majority of the Supreme Court best explains the unwillingness of the Court to recognize the scattered manifestations of state sovereignty as part of a single Tenth

${ }^{127}$ See South Carolina v Baker, 108 S Ct 1355 (1988), in which the Court concluded that the Tenth Amendment afforded no limitation upon congressional power to tax interest income paid on state bearer bonds. The Court treated Congress" action "as if it directly regulated States by prohibiting outright the issuance of bearer bonds," but concluded that it was not one of the "extraordinary defects in the national political process [that] might render congressional regulation of state activities invalid under the Tenth Amendment." Id at 1360 . The Court did not furnish much illumination concerning the nature of the "extraordinary defects" that breathe life into the Tenth Amendment, hinting only that a state's exclusion from the political process or its subjection to invidious discrimination might be sufficient. In essence, the Court concluded that so long as Congress operates in a procedurally regular fashion within its delegated powers, the states may not use the Tenth Amendment to shield themselves from such action. While this conclusion simply restates the notion that the boundaries of state-federal sovereignty are determined by the valid exercise of federal powers, it fails entirely to account for the Court's vigorous use of its power to guard the sovereignty frontier in the jurisdictional sector.

${ }^{128}$ Of course, the Court's view of the commerce power has vacillated over time. See generally Epstein, 73 Va L Rev 1387 (cited in note 69); Felix Frankfurter, The Commerce Clause Under Marshall, Taney and Waite (Quadrangle, 1937); Tribe, American Constitutional Law \$ 5-4, 305-10 (cited in note 2).

${ }_{128}$ Edward S. Corwin, The Passing of Dual Federalism, 36 Va L Rev 1 (1950).

${ }^{130}$ Id at 2. 
Amendment guarantee of such sovereignty. Moreover, the explicit recognition of state sovereignty as a constitutional principle would require the Court to acknowledge other difficult propositions: 1) the national government possesses only a few enumerated powers and purposes; 2) within their respective spheres the states and the national government are each wholly sovereign; and 3) there is a natural and continuing tension between these respective sovereignties. ${ }^{131}$ If the Court was to return to a concept of dual sovereignty, its immediate task would be to rein in congressional actions that transgress the limited, enumerated powers that the Constitution vests in Congress. If those limits were policed, consignment of the Tenth Amendment to the political realm of Congress under Garcia would be far less damaging to state sovereignty; residual state sovereignty would necessarily expand as the Congress became more effectively tethered to its limited and enumerated powers.

Whatever the future development of Tenth Amendment jurisprudence, its current split personality can accommodate much of current Eleventh Amendment doctrine. Sections IV and V of this article attempt to demonstrate that the state sovereign immunity principles that the Court found in the Eleventh Amendment a century after its enactment ${ }^{\mathbf{1 3 2}}$ more properly belong with the collection of Tenth Amendment jurisdictional doctrines that the Court is currently willing to enforce. For that demonstration to be convincing, it is necessary first to sketch the evolution of state sovereign immunity in America, in order to defuse Justice Bradley's assertion in Hans that the Eleventh Amendment was intended to constitutionalize a broad principle of state sovereign immunity from suit in the federal courts.

\section{Sovereign Immunity in America: A Brief History}

At least four hundred years before the first English colonization of America, during the reign of Henry III, English common law held that, while the king could not be sued in his own courts, he was obliged, as the source of justice, to redress wrongs done to his subjects under color of royal authority. This obligation was partly moral and partly legal, but not susceptible to judicial enforcement. ${ }^{133}$ During the reign of Henry III's successor, Edward I, at the turn of the fourteenth century, these conceptions were

131 Id at 4.

${ }_{132}$ See Hans v Louisiana, 134 US 1 (1890).

1ss William Holdsworth, 9 A History of English Law 8 (Metheun, 3d ed 1926) ("Holdsworth"). 
transformed into definite procedures to enable subjects to obtain redress from the crown. ${ }^{134}$ The principal device was the petition of right, which permitted proceedings against the crown by name. ${ }^{135}$ In theory the king could deny a petition of right, thereby preventing the subject's recovery from the royal purse. In practice, the petition of right was issued, not as a matter of royal discretion, but in conformity with law. Petitions were routinely granted whenever plaintiffs made out a prima facie claim for redress. ${ }^{136}$ Issuance of the petition of right merely authorized trial on the merits, but a successful claimant was entitled to recovery directly from the crown. ${ }^{137}$

Other remedies against the crown were also available. The Court of Augmentations, ${ }^{138}$ Court of Wards, ${ }^{139}$ and Court of Surveyors $^{140}$ was each vested with statutory jurisdiction of claims against the crown. Through these courts, English subjects were afforded a right to proceed against the crown for recovery of money or debts, and such recovery was a common occurrence. ${ }^{141}$ Moreover, whatever theoretical immunity the crown possessed, it did not extend to other government officers or to corporate bodies chartered by the Crown. ${ }^{142}$ Accordingly, a suit against such entities

134 Id.

${ }^{136}$ Its close cousin was the "monstrans de droit," the literal translation of which is "manifestation of right." The procedure was employed when a subject contested the crown's claim to property and sought to vindicate his claim solely by reference to the record upon which the crown's claim was based. See 9 Holdsworth at 24-26 (cited in note 133). Both procedures are discussed by Blackstone. See William Blackstone, 3 Commentaries on the Laws of England *256-57 (Chicago, 1979) ("Blackstone").

${ }^{138}$ See 9 Holdsworth at 15 (cited in note 133); Louis L. Jaffe, Suits Against Governments and Officers: Sovereign Immunity, 77 Harv L Rev 1, 4 (1963); Edwin M. Borchard, Government Liability in Tort, 34 Yale L J 1, 6-7, $31-32$ (1924); Edwin M. Borchard, Governmental Responsibility in Tort V, 36 Yale L J 757, 758 (1926); Jacobs, Sovereign Immunity at 6 (cited in note 2).

${ }_{137}$ See, for example, Pawlett v Attorney General, 145 Eng Rep (Hardres 465) 550 (Ex 1668) (recovery by citizen of property that had wrongfully escheated to the crown); Bankers' Case, 14 Howell State Cases 1 (1700) (judgment for citizens against the crown for damages from breach of a contract to pay annuities).

${ }^{138}$ The court was created by statute, 27 Hen VIII, c 27 (1536), to deal initially with the vast quantities of lands confiscated from monasteries following their suppression by Henry VIII.

139 The court was created by statute, 32 Hen VIII, c 46 (1540), to manage the crown's feudal revenues.

140 The court was created by statute, 33 Hen VIII, c 39 (1541), to manage the portions of the royal estates not administered through the Court of Wards.

${ }^{141}$ See Walter C. Richardson, History of the Court of Augmentations, 1536-1554 384 (LSU, 1961). See also H. E. Bell, An Introduction to the History and Records of the Court of Wards and Liveries (Cambridge, 1953).

${ }^{142}$ See Jaffe, 77 Harv L Rev at 3, 9-16 (cited in note 136). 
was governed by ordinary common law.

In eighteenth century colonial America there was no universal belief that the sovereign was immune from suit. The colonial charters themselves commonly contained express provisions that the colonial governments could sue and be sued. These provisions can be found in the Massachusetts charters of $1620^{143}$ and 1629,144 the 1662 Connecticut charter, ${ }^{145}$ and Rhode Island's 1663 charter. ${ }^{146}$ Other colonial charters were silent on the subject but since they were either corporate or individual charters the colonial governments were amenable to suit under ordinary common law principles. When the colonies gained independence and adopted constitutions, not a single colony wrote into its constitution a general grant of sovereign immunity. ${ }^{147}$ Indeed, Connecticut and Rhode Island opted for contrary provisions by adopting their pre-existing charters as state constitutions. ${ }^{148}$ Both Delaware ${ }^{148}$ and Pennsylva$\mathrm{nia}^{150}$ adopted constitutional provisions that permitted the state to

143 F. Thorpe, ed, 3 The Federal and State Constitutions, Colonial Charters and Other Organic Laws 1827, 1831 (GPO, 1909) ("Thorpe"); W. Swindler, ed, 5 Sources and Documents of United States Constitutions 16, 19 (Oceana, 1975) ("Swindler"):

And further, our Will and Pleasure is, that the said Councill, for the time being, and their Successors, shall have full Power and lawful authority, by the Name aforesaid, to sue and be sued; implead and be impleaded; answer, and to be answered, unto all Manner of Courts and Places that now are, or hereafter shall be, within this our Realme and elsewhere, as well temporal as spiritual, in all Manner of Suits and Matters whatsoever, and of what Nature or Kinde soever such Suite or Action be or shall be.

144 See 3 Thorpe at 1846, 1852 (cited in note 143), and 5 Swindler at 32, 36 (cited in note 143):

[The Colony] shall and maie be capeable and enabled aswell to implead, and to be impleaded, and to prosecute, demaund and aunswere, and be aunswered unto, in all and singuler Suites, Causes, Quarrells, and Accons, of what kinde or nature soever.

${ }^{145} 1$ Thorpe at 529, 530 (cited in note 143) (cited in note 145); 2 Swindler at 131 (cited in note 143):

[the Colony is] . . capable in the Law, to plead and to be impleaded, to answer and to be answered unto, to defend and to be defended in all and singular Suits, Causes, Quarrels, Matters, Actions, and Things, of what Kind or Nature soever.

146 6 Thorpe at 3211,3213 (cited in note 143); 8 Swindler at 363 (cited in note 143):

[The Colony is] ... capable, in the lawe, to sue and bee sued, to pleade and be impleaded, to answeare and bee answeared unto, to defend and to be defended, in all and singular suites, causes, quarrels, matters, actions and things, of what kind or nature soever ....

${ }^{167}$ Gibbons, 83 Colum L Rev at 1897-98 (cited in note 2).

148 Id at $1898, \mathrm{n} 42$.

1491 Thorpe at 568-69 (cited in note 143); 2 Swindler at 205-06 (cited in note 143) ("Suits may be brought against the State, according to such regulations as shall be made law.")

150 5 Thorpe at 3092, 3101; 8 Swindler at 286, 293 ("Suits may be brought against the commonwealth in such manner, in such courts, and in such cases as the legislature may by law direct.") 
waive sovereign immunity.

The evidence of colonial Americans' rejection of sovereign immunity is not limited to the charter provisions. To be sure, Blackstone restated the fiction that the "king can do no wrong"161 and proceeded to argue that "whatever may be amiss in the conduct of public affairs is not chargeable personally on the king; nor is he, but his ministers, accountable for it to the people."152 But even Blackstone admitted that this doctrine was not a barrier to private recovery from the crown; though the petition of right was obtainable as "a matter of grace, though not upon compulsion,"153 it would of course be granted, for "to know of any injury [to his subjects] and to redress it are inseparable in the royal breast, ... [The law] issues as of course, in the king's own name, his orders to his judges to do justice to the party aggrieved."154 These principles and procedures were transplanted to early America. St. George Tucker, commenting in 1803 on Blackstone's Commentaries, noted that "[a]ny person who is entitled to demand against the commonwealth any right in law or equity, may petition the high court of chancery or the district court, holden at Richmond, for redress, and such court shall proceed to do right thereon."15s

Moreover, despite Blackstone's importance to colonial law, he was not considered infallible. James Wilson, in his law lectures delivered at the College of Philadelphia in 1790-91, frankly stated that "I cannot consider him [Blackstone] as a zealous friend of republicanism." ${ }^{\prime 166}$ In discoursing upon Blackstonian conceptions of sovereignty, Wilson commented: "The dread and redoubtable sov-

1513 Blackstone at *254 (cited in note 135).

${ }^{182}$ Id at *254-55.

15s 1 id at $* 236$.

${ }^{164} 3$ id at $* 255$ (emphasis in original). This concept has long been fundamental to English legal thought. Chief Justice Holt phrased it most broadly when he opined that if the plaintiff "has a right ..., of necessary consequence he has an action to vindicate and maintain that right, .... It is a vain thing to imagine that there should be a right without a remedy; want of right and want of remedy are termini convertibles [reciprocal] .... [I]t is without a precedent to a have a right without a remedy." Ashby $v$ White, $6 \mathrm{Mod}$ Rep 45, 53, 87 Eng Rep 808, 815 (QB 1702). The concept was readily transferred to America. See Federalist 43 (Madison) in Clinton Rossiter, ed, The Federalist Papers 271, 274 (Mentor, 1961). ("But a right implies a remedy ..."). See also Marbury $v$ Madison, 5 US (1 Cranch) 137, 162-63 (1803) (quoting 3 Blackstone at ${ }^{*} 23$, ${ }^{*} 109$ (cited in note 135), to the same effect). There is still vitality to the notion. See Cal Civ Code $\S 3523$ (West 1984) ("for every wrong there is a remedy").

${ }^{205}$ St. George Tucker, 2 Blackstone's Commentaries: With Notes of Reference, to the Constitution and Laws, of the Federal Government of the United States: and of the Commonwealth of Virginia 242-43 n 5 (Birch \& Small, 1803).

${ }^{168}$ Robert Green McCloskey, ed, 1 The Works of James Wilson 79 (Harvard, 1967). 
ereign, when traced to his ultimate and genuine source, has been found, as he ought to have been found, in the free and independent man. This truth, so simple and natural, and yet so neglected and despised, may be appreciated as the first and fundamental principle in the science of government."157 From this principle it was an easy step to denial of any principle of sovereign immunity:

[T] he only reason, why a free and independent man was bound by human laws was this-that he bound himself. Upon the same principle on which he becomes bound by the laws, he becomes amenable before the courts of justice, which are formed and authorized by those laws. If one free and independent man, an original sovereign, may do all this; why may not an aggregate of free and independent men, a collection of original sovereigns, do this likewise? The dignity of the state is compounded of the dignity of its members. If the dignity of each singly is undiminished, the dignity of all jointly must be unimpaired. Is a man degraded by the manly declaration, that he renders himself amenable to justice? Can a similar declaration degrade a state? ${ }^{158}$

At the core of these pronouncements is the belief that the only true sovereignty is that which resides in the people themselves. Accordingly, these original sovereigns gave to their governmental agents, both national and state, certain limited powers. Professor Amar has contended that this fundamental principle knocks the props out of the argument that governments, national or state, ought to possess immunity from accountability for their wrongdoing. ${ }^{159}$ But the theory of popular sovereignty does not answer the jurisdictional question of which court system will hear claims against the states. In antebellum America a bitter debate raged over whether the locus of sovereignty was in the people of each state, or the people of the nation as a whole. ${ }^{160}$ If sovereignty was

167 Id at 81.

${ }^{188}$ McCloskey, 2 Works of James Wilson at 497 (cited in note 156). Wilson's lectures on sovereignty presaged his opinion in Chisholm $v$ Georgia. See text at notes 221-28. To be sure, Wilson was rather extreme in his views of popular sovereignty. Not every colonial American shared his views on this subject. Compare Patrick Henry's comments in the Virginia ratifying convention, quoted in note 168 .

158 Amar, 96 Yale L $J$ at 1484-92 (cited in note 2).

${ }^{160}$ In the first half of the nineteenth century, Northerners and Southerners alike manipulated state sovereignty principles to serve their immediate political objectives. When the War of 1812 threatened New England's shipping and commercial interests, New England Federalists called the Hartford Convention to consider seriously the wisdom of secession. See generally James M. Banner, To the Hartford Convention: The Federalists and the 
vested in the people of the constituent states, it would make sense to deny the federal courts the power to hear claims against the states, for those governments were the corporate agents of the people of each state, and the federal government was the mere agent of the states. But if sovereignty was vested in the people of the entire nation, state governments could claim no paramount role, for the federal government was the sovereign's agent, and the state governments acted as agent for slivers of the whole. While this debate died in the bloody woods and fields of Virginia and was interred at Appomattox Courthouse, ${ }^{161}$ it had currency when the Constitution was framed and the Eleventh Amendment adopted. Original conceptions of sovereignty and sovereign immunity cannot be understood without keeping these opposing poles of thought in

Origins of Party Politics in Massachusetts, 1789-1815 (Knopf, 1969). Twenty years later, when the "Abominable Tariff" of 1832 was enacted, South Carolinians preached John C. Calhoun's doctrine of nullification. See generally David Franklin Houston, A Critical Study of Nullification in South Carolina (Russell \& Russell, 1896); Robert V. Remini, Andrew Jackson and the Course of American Freedom, 1822-1832 137, 160, 232-37, 381, 387-89 (Harper \& Row, 1981); Robert V. Remini, Andrew Jackson and the Course of American Democracy, 1833-1845 8-44 (Harper \& Row, 1984).

In another twenty years, radical northern abolitionists embraced nullification principles in order to defeat the operation of the Fugitive Slave Act of 1850, 9 Stat 462 . The Act was passed in part as a result of Prigg $v$ Pennsylvania, 41 US (16 Pet) 539 (1842), and the subsequent northern state legislative responses to Prigg that sought to vitiate the existing Fugitive Slave Act of 1793 . The new Act vested in the federal courts effective machinery for the claim and delivery of apprehended fugitive slaves. Some northern states reacted by declaring that the federal courts had no power to review state court grants of habeas corpus to petitioners seeking freedom from federal custody. See In re Booth, 3 Wis 1, 157 (1854). The United States Supreme Court firmly rejected this position in Ableman v Booth, 62 US (21 How) 506 (1859), but the states remained obdurate. See Oberlin Rescue Cases, 9 Ohio St 77 (1859). See also Charles Warren, 3 The Supreme Court in United States History 42-79 (Little, Brown, 1922).

There is no reason to think that this pattern of manipulation died with the Civil War. Consider, as just one example, the pre- and post-1937 interpretations of the Commerce Clause. See Epstein, 73 Va L Rev 1387, 1399-1454 (cited in note 69) Moreover, following Brown v Board of Education, 347 US 483 (1954), eight southern legislatures formally "nullified" Brown. See Alabama's nullification resolution, reprinted in William Murphy, et al, American Constitutional Interpretation 280-81 (Foundation, 1986). Of course, this effort failed. See also Cooper v Aaron, 358 US 1 (1958), and compare Edwin Meese III, The Law of the Constitution, 61 Tulane L Rev 979, 986-87 (1987) (criticizing the Court's dictum in Cooper $v$ Aaron that the decisions of the Supreme Court are nothing less than "the supreme law of the land." Cooper, 358 US at 18).

${ }^{161}$ The conventional labels placed on this conflict contain an implicit endorsement of a particular sovereignty locus. "Civil War" indicates a belief that sovereignty was vested in the people of the whole nation; "War Between the States" suggests equally strongly that the conflict was between independent sovereigns. The unconventional "War for Southern Independence" is descriptive without carrying a commitment to a sovereignty viewpoint. Nevertheless, to avoid confusion I have used the conventional and prevailing term, "Civil War," throughout this article. 
mind.

Though there is little historical evidence bearing on what the general "understanding" of state sovereign immunity was at the time of the Constitution's adoption, some help can be found in the debates of the several state ratifying conventions. The issue arose in the context of enforcement of the 1783 peace treaty between Britain and the nascent United States. ${ }^{162}$ The treaty required the British to evacuate all military posts in America and to leave behind all slaves. The Americans agreed not to frustrate collection of American debts by British creditors and to refrain from any further escheat of loyalist property by the states. The British did not comply with the provisions requiring their abandonment of slaves. ${ }^{163}$ Angered by the violation, southern states retaliated by imposing statutory obstacles to the collection of debts by British creditors. ${ }^{164}$ Thus, when the several states debated ratification of the Constitution, delegates were concerned both with the possibility that British creditors might be able to enforce their claims against states and private citizens in the federal courts and with the fear that the nation might not survive if it could not enforce the peace treaty. In the major state conventions, these issues were raised in debates over the scope of the judicial power. Opponents of ratification argued that the federal judicial power would be used to entertain suits against the states by British creditors. ${ }^{165}$ Those in favor of ratification generally agreed. ${ }^{166} \mathrm{~A}$ few proponents, such as James Madison, may have dissembled by suggesting that a state could not be sued without its consent, ${ }^{\mathbf{1 6 z}}$ but this suggestion was

162 For the provisional peace treaty, see Treaty of Nov 30, 1782, 8 Stat 54; for the final treaty, see Treaty of Paris, 8 Stat 80 (1783).

${ }_{103}$ Samuel F. Bemis, Jay's Treaty: A Study in Commerce and Diplomacy 63, 130-31 (Yale, 1962).

${ }^{184}$ See Samuel F. Bemis, A Diplomatic History of the United States 72 (Holt, Rinehart \& Winston, 1936); Gibbons, 83 Colum L Rev at 1900-1902 (cited in note 2).

185 See, for example, George Mason's arguments in the Virginia convention, Jonathan Elliot, 3 The Debates in the Several State Conventions of the Adoption of the Federal Constitution 526-27 (2d ed 1836) ("Elliot's Debates").

${ }^{16 s}$ See, for example, James Wilson's remarks in the Pennsylvania convention, 2 Elliot's Debates at 490 (cited in note 165). See also Paul L. Ford, ed, Pamphlets on the Constitution of the United States 149 (Da Capo, 1888) (Tench Coxe asserted that Article III permitted a citizen to sue a state in federal court rather than in "a court constituted by the state, with which ... his dispute is.") Professor Jacobs contends that the Committee of Detail of the Constitutional Convention, which drafted the final version of Article III, probably interpreted it to permit suit by a citizen of one state against another state. Jacobs, Sovereign Immunity at 25 (cited in note 2).

${ }^{167}$ In rebutting Mason, Madison asserted that it "appears to me that ... [Article III] can have no operation but this-to give a citizen the right to be heard in the federal courts; and if a state should condescend to be a party, this court may take cognizance of it." 3 
hotly denounced as a perverse fiction by such Constitutional opponents as Patrick Henry. ${ }^{168}$

In Federalist 81, Alexander Hamilton declared that "[i]t is inherent in the nature of sovereignty not to be amenable to the suit of an individual without its consent. This is the general sense, and the general practice of mankind; and the exemption, as one of the attributes of sovereignty, is now enjoyed by the government of every State in the Union."169 But, as Judge Gibbons has demonstrated, ${ }^{170}$ this passage does not suggest that the federal courts lack jurisdiction over a private claim against a state, but rather that no substantive right of action against a state for its pre-Constitution public debt could exist absent a state's consent to grant such a right. While the Constitution would vest the federal courts with jurisdiction to hear claims made against a state by foreigners or the citizens of another state, it would not displace state law as the rule of decision. Thus, if a state provided that it could not be held liable on its debts by reason of its sovereign immunity, the federal courts, though invested by Article III with jurisdiction to hear the issue, would apply the state law shield of immunity to defeat any claim. ${ }^{171}$ Certainly Judge Gibbons's view is more consistent with

Elliot's Debates at 533 (cited in note 165). Jacobs argues that Madison took this position only to secure ratification in the Virginia Convention. Jacobs, Sovereign Immunity at 34 (cited in note 2).

${ }^{188}$ Henry's response to Madison was as follows:

If gentlemen pervert the most clear expressions, and the usual meaning of the language of the people, there is an end of all argument. What says the paper? That it shall have cognizance of controversies between a state and citizens of another state, without discriminating between plaintiff and defendant. What says the honorable gentleman? The contrary - that the state can only be plaintiff. When the state is debtor, there is no reciprocity.

3 Elliot's Debates at 543 (cited in note 165). John Marshall replied to Henry:

I hope that no gentleman will think a state will be called at the bar of the federal court. Is there no such case at present? Are there not many cases in which the legislature of Virginia is a party, and yet the state is not sued? It is not rational to suppose that the sovereign power should be dragged before a court. The intent is, to enable states to recover claims of individuals residing in other states. I contend this construction is warranted by the words. ... I see a difficulty in making a state defendant, which does not prevent its being plaintiff.

3 id at 555-56.

${ }^{169}$ Federalist 81 (Hamilton), in Federalist Papers at 481, 487 (cited in note 154) (emphasis in original).

${ }^{170}$ Gibbons, 83 Colum $\mathrm{L}$ Rev at 1908-12 (cited in note 2).

${ }^{171}$ Justice Brennan and some commentators have contended that the fundamental error of Chisholm $v$ Georgia, 2 US (2 Dall) 419 (1793) was in failing to recognize that, while the Court may have jurisdiction over the matter, the rule of decision should be that indicated by state law. Atascadero, 473 US at 282-83, and at 289 (Brennan dissenting); Amar, 96 Yale L J at 1469-73 (cited in note 2); Note, More Plenary Than Thou: A Post-Welch Compromise Theory of Congressional Power to Abrogate State Sovereign Immunity, 88 
Hamilton's contemporaneous comments in Federalist 80 to the effect that federal courts under the Constitution would possess power to enforce claims based on violations of federal law directly against a state and its public fisc. ${ }^{172}$ Even more revealing is a contemporary remark of Hamilton following Chisholm. Hamilton described opposition to Chisholm as "opposition to the Constitution," "173 a view that reinforces Judge Gibbons's interpretation of Hamilton's intent in penning Federalist 81.

Furthermore, too much emphasis can be placed on The Federalist. The Federalist essays were basically newspaper propaganda designed to secure an immediate political result. Like all political campaigners, Hamilton may not have been above a little strategic prevarication; his principal co-author later admitted that The Federalist essays were branded with the "zeal of advocates."174 Thus,

Colum L Rev 1022, 1031 (1988). This point is taken too far, for the majority decided only the jurisdictional issue; the rule of decision on the merits of Chisholm's assumpsit claim was expressly left open. See text at notes 188-259.

${ }^{172}$ Gibbons, 83 Colum L Rev at 1910 \& n 104 (cited in note 2). In Federalist 80, Hamilton observed that the Constitution prohibits the states from a variety of actions, including the "imposition of duties on imported articles and the emission of paper money. ... No man of sense will believe that such prohibitions would be scrupulously regarded, without some effectual power in the government to restrain or correct the infractions of them. This power must either be a direct negative on the State laws, or an authority in the federal courts, to over-rule such as might be in manifest contravention of the articles of Union." Federalist 80 (Hamilton), in Federalist Papers at 475, 475-76 (cited in note 154). Hamilton also cited the Privileges and Immunities Clause, US Const, Art IV, § 2, cl 1, for the proposition that "the national judiciary ought to preside in all cases in which one State or its citizens are opposed to another State or its citizens." Federalist 80 (Hamilton), in Federalist Papers at 475, 478 (cited in note 154). Nevertheless, Hamilton observed that "the state governments would clearly retain all the rights of sovereignty which they before had, and which were not, by that act, exclusively delegated to the United States." Federalist 32 (Hamilton), in Federalist Papers at 197, 198 (cited in note 154) (emphasis in original). From this premise, Hamilton constructed an argument that the states and federal government possessed concurrent authority over a wide range of subjects, a necessary consequence of the Constitution's "division of the sovereign power; and the rule that all authorities, of which the States are not explicitly divested in favor of the Union, remain with them in full vigor. . . ." Id at 201. Hamilton admitted that the exercise of concurrent authority "might now and then not exactly coincide, and might require reciprocal forbearances." Id at 200 . The collision of federal court jurisdiction over claims against states with concurrent state authority to determine the limits of its liability may have been thought by Hamilton to be such an instance.

Professor Nowak argues that Federalist 80 and 81 can be reconciled on the basis that Hamilton thought Article III did not vest automatic jurisdiction in the federal courts to entertain suits against a state by citizens of another state, but that Article III did give Congress the power to grant jurisdiction in such cases. Nowak, 75 Colum L Rev at 1429 (cited in note 2).

173 Harold Syrett, ed, 17 Papers of Alexander Hamilton 9, 12 \& n 13 (Columbia, 1972) (Minutes of Conference of Aug 2, 1794), quoted in H. Jefferson Powell, Rules for Originalists, 73 Va L Rev 659, 681 n 51 (1987).

1743 Letters and Other Writings of James Madison 435-36 (Lippincott, 1865) (Letter 
when Hamilton asserts flatly that sovereign immunity "is now enjoyed by the government of every State in the Union,"175 there is no reason uncritically to accept this as an accurate statement of law. Virginia, for example, followed English procedure in permitting private citizens to sue the state by name. ${ }^{176}$ Zephaniah Swift, in his commentaries upon Connecticut law, does not discuss state immunity from suit, but does indicate that neither state officials ${ }^{\mathbf{1 7 7}}$ nor municipalities ${ }^{178}$ were immune.

In his comprehensive survey of the debates, Judge Gibbons concludes that "the best evidence is that each convention interpreted the judiciary article, as originally written, to allow the states to be sued in the federal courts."179 Yet, as recently as 1974, the Supreme Court has claimed that a belief in state sovereign immunity was "the prevailing view at the time of the ratification of the Constitution."180 By 1987, only a mere plurality Court would continue to rely on isolated statements of Madison, Marshall, and Hamilton to support the conclusion that a belief in state sovereign immunity prevailed at the time of the ratification, ${ }^{181}$ and even that plurality had to concede that "the intentions of the Framers and Ratifiers were ambiguous" on the issue. ${ }^{182}$

from Madison to Edward Livingston, April 17, 1824).

${ }^{175}$ See Federalist 81 (Hamilton) in Federalist Papers at 481, 487 (cited in note 154) (emphasis in original).

${ }^{178}$ See text at note 155.

177 Zephaniah Swift, A Digest of the Laws of the State of Connecticut 541-48 (Converse, 1822). State officials did not enjoy immunity because an official acting in violation of law was acting outside the scope of his agency. See generally, David E. Engdahl, Immunity and Accountability for Positive Governmental Wrongs, 44 Colo L Rev 1 (1972).

${ }^{178}$ Swift, Laws of Connecticut at 552 (municipalities liable for injuries sustained due to negligent repair of bridges and roads); and at 589 (process served on municipality by serving selectman). Too much significance can be attached to the susceptibility of municipalities to private damage actions. In eighteenth and early nineteenth century America, municipalities were treated as corporations, not sovereigns. See James Kent, 2 Commentaries on American Law 275 (Halsted, 1826). They were, however, public corporations invested with a sliver of the state's sovereignty. See Arthur J. Jacobson, The Private Use of Public Authority: Sovereignty and Associations in the Common Law, 29 Buff L Rev 599 (1980). Thus, Chief Justice Jay argued in his Chisholm opinion that the exposure of municipal public corporations to private suit was a basis for denying immunity to its functional equivalent, a state. Chisholm, 2 US (2 Dall) at $472-73$.

178 Gibbons, 83 Colum L Rev at 1913 (cited in note 2). See also Jacobs, Sovereign Immunity at 40 (cited in note 2). But see Charles Warren, 1 The Supreme Court in United States History 91 (Little, Brown, 1923).

180 Edelman v Jordan, 415 US 651, 660-62 n 9 (1974).

181 See notes 167-69.

282 Welch, $107 \mathrm{~S} \mathrm{Ct}$ at 2951 . Most commentators conclude that the records of the Constitutional Convention are of no help whatsoever, but contend that evidence extrinsic to the Convention suggests that no universal belief in state sovereign immunity existed at the time. See, for example, Jacobs, Sovereign Immunity at 21-25 (cited in note 2); Nowak, 75 Colum 
What did exist in 1787 was a robust debate over the nature of sovereignty. Certain Federalists, such as James Wilson, were outspoken in their conviction that sovereignty was exclusively vested in the people of the nation as a whole. ${ }^{183}$ The anti- Federalists were equally fervid in their contention that the states possessed sovereignty that ought not be compromised by constitutional union. ${ }^{184}$ Professor Orth aptly declares that " $[t]$ he search for the original understanding on state sovereign immunity bears this much resemblance to the quest for the Holy Grail: there is enough to be found so that the faithful of whatever persuasion can find their heart's desire."186 If there can be no objective certainty to that quest, perhaps some enlightenment can be attained by a perusal of the history of the Eleventh Amendment in the courts.

\section{The Evolution of the Eleventh Amendment: From Constitutional Union to Reconstruction}

Most histories of the Eleventh Amendment in the courts are tales of doctrine responding to the felt political necessities of the times. ${ }^{186}$ These accounts conclude that the notion of state sovereign immunity was grafted onto the Eleventh Amendment as a wrong, or at least unprincipled, act. These histories variously conclude that the amendment's reception in the courts prior to Reconstruction confirms that the amendment was then regarded as nothing more than a narrowing construction of one affirmative jurisdictional grant of Article III, having no impact whatever on the "arising under" head of jurisdiction in Article III. ${ }^{187}$ This account is incomplete and unpersuasive.

\footnotetext{
L Rev at 1422-1430 (cited in note 2).

18s See, for example, James Wilson's opening comments to the Pennsylvania ratification convention on December 1, 1787. 2 Elliot's Debates at 443-44 (cited in note 165).

184 Emblematic of these thinkers was Patrick Henry:

Who authorized them [the federal convention] to speak the language of, We, the people, instead of, We, the states? States are the characteristics and the soul of a confederation. If the states be not the agents of this compact, it must be one great, consolidated, national government, of the people of all the states. . . . Here is a resolution as radical as that which separated us from Great Britain. It is radical in this transition; our rights and privileges are endangered, and the sovereignty of the states will be relinquished: and cannot we plainly see that this is actually the case?

3 Elliot's Debates at 22, 44 (cited in note 165) (emphasis in original).

${ }^{185}$ Orth, The Judicial Power at 28 (cited in note 2).

${ }^{186}$ See, for example, Orth, The Judicial Power (cited in note 2); Jacobs, Sovereign Immunity (cited in note 2); Gibbons, 83 Colum L Rev 1889 (cited in note 2).

187 See Fletcher, 35 Stan L Rev at 1060-61 (cited in note 2); Gibbons, 83 Colum L Rev at 1941-68 (cited in note 2); Field, $126 \mathrm{U} \mathrm{Pa} \mathrm{L} \mathrm{Rev} \mathrm{at} 541$ (cited in note 2). See also Justice Brennan's views in cases cited in note 2.
} 


\section{A. Chisholm v Georgia}

The story inevitably begins with Chisholm $v$ Georgia. ${ }^{188}$ The case cannot be understood apart from the context of efforts by the Washington Administration to enforce the peace treaty of 1783 with Great Britain in order to validate the infant American republic's foreign policy. Among the salient provisions of the treaty was an article guaranteeing that British creditors "shall meet with no lawful impediment to the recovery of the full value in sterling money, of all bona fide debts heretofore contracted."189 Yet, many states had enacted statutes expropriating debts due British creditors and making Continental paper currency or bills of exchange legal tender. ${ }^{190}$ If the young nation could not enforce the terms of the peace treaty at home, it would be unable to command either respect or reciprocal enforcement abroad. Closer to home, the British refused to evacuate seven frontier posts in the Northwest Territory until the Americans had complied with their end of the bargain. ${ }^{191}$

Chisholm did not directly involve the peace treaty; rather, it was a superficially simple contract action arising under the federal courts' jurisdiction over controversies "between a State and Citizens of another State."192 In 1777, Robert Farquhar, a South Carolina merchant, sold Georgia military goods for use in the revolu-

${ }^{188} 2$ US (2 Dall) 419 (1793). Chisholm was the first case to be specifically overruled by constitutional amendment. The other such constitutional amendments and the cases to which they were directed are: US Const, Amend XIV, § 1, Scott v Sandford, 60 US (19 How) 393 (1857); US Const, Amend XVI, Pollock v Farmers' Loan \& Trust Co., 157 US 429 (1895); US Const, Amend XXVI, Oregon v Mitchell, 400 US 112 (1970).

189 8 Stat at 56.

190 See Gibbons, 83 Colum L Rev at 1899-1902 and sources cited at $1901 \mathrm{n} 55$ (cited in note 2). It is incorrect to imply, as does Gibbons, that Southern planters were almost universally opposed to the provisions of the peace treaty securing the claims of British creditors. To support this contention, Gibbons cites Professor Morris's account of George Mason's May 6, 1783 letter to Patrick Henry. See id at 1901 n 59. But Morris misses the full import of the correspondence, for Mason actually approved of the treaty, was greatly concerned that state attempts to frustrate British creditors would rekindle hostilities, and thought that any repudiation of debts would be both dishonorable and "short sighted Policy." Letter to Patrick Henry, May 6, 1783, in Robert A. Rutland, ed, 2 The Papers of George Mason 77071 (U NC, 1970). The passage quoted by Morris actually reads in full:

In Conversation upon this Subject, we sometimes hear a very absurd Question 'If we are now to pay the Debts due to British Merchants, what have we been fighting for all this while?' Surely not to avoid our just Debts, or cheat our Creditors; but to rescue our Country from the Oppression \& Tyranny of the British Government, and to secure the Rights \& Liberty of ourselves, \& our Posterity; which we have happily accomplished. Id at 771 .

191 See, for example, Orth, The Judicial Power at 17 (cited in note 2).

102 US Const, Art III, § 2, cl 6. 
tionary war effort. Although Georgia had authorized payment to Farquhar, the state failed to do so during Farquhar's life. ${ }^{193}$ Alexander Chisholm, Farquhar's executor and a fellow South Carolinian, was rebuffed by the Georgia legislature in his attempts to secure payment of the debt. Accordingly, Chisholm brought suit in the federal trial court for Georgia, invoking the court's diversity jurisdiction to assert his claim in assumpsit. ${ }^{194}$ Georgia's defense was simply to assert that it was immune from suit in any court. ${ }^{195}$ That was good enough for Justice Iredell, riding circuit, and District Judge Nathaniel Pendleton, for they promptly dismissed the complaint. ${ }^{196}$

Unwilling to forget his $£ 100,000$ claim, ${ }^{197}$ Chisholm filed the action again, this time as an original proceeding in the Supreme Court. Georgia refused to appear, again claiming sovereign immunity and challenging the Court's jurisdiction. ${ }^{188}$ Chisholm's counsel, Attorney General Edmund Randolph, ${ }^{199}$ moved for a default judg-

${ }^{193}$ See Jacobs, Sovereign Immunity at 47 (cited in note 2).

104 Farquhar's Executor v Georgia, (CC D Ga 1791), an unreported case discussed in Jacobs, Sovereign Immunity at $47 \&$ n 29 (cited in note 2).

${ }^{208}$ "[T] $\mathrm{T}$ he state of Georgia cannot be drawn or compelled to answer against the will of the said State before any Justices of any Court of Law or Equity whatsoever." Farquhar's Executor v Georgia, (CC D Ga 1791), quoted in Jacobs, Sovereign Immunity at 47.

${ }^{108}$ Id. It is possible that Iredell, sitting as a circuit judge, was unpersuaded by Georgia's immunity claim but thought the court lacked jurisdiction. The 1789 Judiciary Act did not confer state-citizen diversity jurisdiction on the circuit courts. See Judiciary Act of 1789 , ch $20, \S 11,1$ Stat $73,78-79$.

197 The original contract, negotiated with Farquhar by Georgia's commissioners, specified a purchase price of $\$ 63,605$, South Carolina currency. Chisholm's prayer in his circuit court action was for $\$ 100,000$ sterling. See Jacobs, Sovereign Immunity at 47 (cited in note 2). The difference represented pre-judgment interest at less than 5\% annually. Chisholm's claim was quite large. Assuming an approximately equal rate of exchange, at London prices in $1790, £ 100,000$ sterling would have purchased approximately 285,000 bushels of wheat. See Samuel Blodget, Economica: A Statistical Manual for the United States of America 147 (Blodget, 1806). By comparison, that same quantity of wheat would cost at least $\$ 1.1$ million today. Cash Prices, Wall St J C12 (Feb 24, 1989). While Chisholm's claim was large, the original contract appears to have been negotiated at arm's length, so Georgia's rancor was probably not born out of a belief that the contract price was padded.

${ }_{198}$ Counsel for Georgia did not appear before the Court to argue the case, but did deliver a written remonstrance, the text of which was also published in a Philadelphia newspaper. See Chisholm, 2 US (2 Dall) at 419; Amar, 96 Yale L J at 1468 and n 176 (cited in note 2). In substance, Georgia contended that Article III's state-citizen diversity clause should be read to confer jurisdiction only when a state sued an out-of-state citizen, but not the reverse.

${ }^{199}$ It was common practice in the early republic for the nation's attorney general to carry on a private practice while performing his public functions. See Albert J. Beveridge, 2 Life of John Marshall 122-23 (Houghton Miffin, 1916); Moncure Daniel Conway, Omitted Chapters of History Disclosed in the Life \& Papers of Edmund Randolph 133, 135 (New York, 1888). It is also possible that Randolph's representation of Chisholm was merely a convenient device to enable Randolph to assert the national government's position in a case 
ment. The implications of Georgia's position were clear: if states could not be compelled to answer in a federal court, British creditors would be forced to seek recourse in hostile state courts where, through defenses provided by state statutes designed to frustrate British creditors, the American states would always win. Similarly, loyalists invoking the 1783 peace treaty to recover property confiscated by the states would be forced into state courts. ${ }^{200}$ Thus, enforcement of the peace treaty effectively depended upon permitting British creditors to sue the states, their officers, and the individual debtors in federal courts.

In urging the five justices ${ }^{201}$ to find for Chisholm, Randolph devoted the bulk of his argument to defending the proposition that the Supreme Court had jurisdiction. He contended that constitutional authority was granted both by the literal text of Article III and by "the spirit of the constitution, or rather its genuine and necessary interpretation." ${ }^{202}$ Because the Constitution imposes a number of restrictions upon the states, ${ }^{203}$ Randolph argued, it was surely contemplated that states be legally accountable for violation of these restrictions. Such accountability required the susceptibility of states to suit, for "unconstitutional actions must pass with-

of great importance to the allocation of power between the states and the federal government. On at least one prior occasion, in Hayburn's Case, 2 US (2 Dall) 409 (1792), Randolph's representation of a private party was undertaken for similar reasons of state. See Maeva Marcus and Robert Teir, Hayburn's Case: A Misinterpretation of Precedent, 1988 Wis L Rev 527, 534-41.

${ }^{200}$ Article V of the peace treaty obligated the United States to "recommend" to the states that they return loyalist property that had already been completely confiscated. 8 Stat at 56. Article VI of the treaty prohibited further confiscations and barred the completion of pending escheats. Id.

${ }^{201}$ The Court heard and decided Chisholm in Philadelphia's intimate Old City Hall, its quarters while Philadelphia served as the nation's capital. The Court had six seats, but there was one vacancy when Chisholm was heard and decided. The Chief Justice was John Jay, author of The Federalist, one of the negotiators of the 1783 peace treaty, and delegate to New York's ratification convention. His fellow justices were James Wilson, legal scholar, delegate to the 1787 Constitutional Convention, member of that Convention's Committee on Detail, and delegate to Pennsylvania's ratifying convention; John Blair, delegate to the 1787 Convention and to Virginia's ratifying convention; James Iredell, pro-ratification leader of the North Carolina ratifying convention; and William Cushing, chairperson of the Massachusetts ratification convention. Surely this was a Court magnificently equipped to understand whatever original understanding there may have been with respect to state immunity from suit.

${ }^{202}$ Chisholm, 2 US (2 Dall) at 421 (argument of Randolph) (emphasis in original).

${ }^{203}$ Randolph cited as examples the prohibitions against unwarranted suspension of habeas corpus, bills of attainder and ex post facto laws, entry into treaties, granting of letters of marque, coinage, issuance of paper money or bills of credit, impairment of contracts, imposition of import, export or tonnage duties, and maintaining armed forces. Id at 421-22. 
out censure, unless States can be made defendants. ... These evils ... cannot be corrected without a suit against the state"204 by aggrieved citizens.

Randolph's conclusion derived further support from his own view of the nature of the federal union. Just as individual Americans had created the states, the states had created the national government with their "free will, arising from absolute independence."205 Randolph extended the analogy to the ability of the sovereign to subject to legal liability those who formed it. "The states are in fact assemblages of these individuals who are liable to [legal] process. The limitations which the federal government is admitted to impose upon their powers, are diminutions of sovereignty, at least, equal to the making of them defendants." ${ }^{208}$ Any other result would risk domestic and international strife. ${ }^{207}$

Not only, Randolph argued, did Article III confer jurisdiction undisturbed by any reservation of state sovereignty, but Congress had acted to empower the federal courts to exercise that jurisdiction. He seized on $\S 14$ of the 1789 Judiciary Act, which gave the federal courts power to issue all writs "which may be necessary for the exercise of their respective jurisdictions, and agreeable to the principles and usages of law."208 Surely this Act gave the Court power to employ the full panoply of legal procedure, argued Randolph. ${ }^{209}$

Randolph then briefly addressed the subsidiary issue: did an action of assumpsit lie against Georgia? While this issue was laden with all the questions concerning the existence of a general federal common law as recognized by Swift $v$ Tyson ${ }^{210}$ and later repudiated by Erie Railroad Co. $v$ Tompkins, ${ }^{211}$ Randolph dismissed the matter as one of capacity: "Is not a state capable of making a promise? Certainly; as a state is a moral person, being an assemblage of individuals, who are moral persons."212 Neither Randolph nor the justices addressed a key aspect of this issue: was the rule of

201 Id at 422.

$205 \mathrm{Id}$ at 423.

$208 \mathrm{Id}$.

207 Id at 424-25.

${ }^{208}$ Judiciary Act of 1789, ch 20, $\S 14,1$ Stat 73, 82, quoted in Chisholm, 2 US (2 Dall) at 426 .

${ }^{209}$ Chisholm, 2 US (2 Dall) at 426-27. Apparently, the principle that the Supreme Court's original jurisdiction is derived directly from the Constitution was not firmly established at this time.

${ }^{210} 41$ US (16 Pet) 1 (1842).

21304 US 64 (1938).

${ }^{212}$ Chisholm, 2 US (2 Dall) at 428. 
decision one of local, federal, or general common law? ${ }^{213}$ While $\S$ 34 of the Judiciary Act compelled the Court to follow "the laws of the several states ... [as] rules of decision" in trials at common $\mathrm{law}^{214}$ its applicability to Chisholm went wholly unmentioned in Randolph's argument and in the justices' opinions.

Perhaps the simplest explanation is that the four justices in the majority-Jay, Wilson, Blair, and Cushing-viewed the case as wholly jurisdictional. ${ }^{216}$ Georgia had refused to appear, vehemently denying jurisdiction, and Chisholm sought a default judgment. The Court did not grant Chisholm's request; it merely asserted its jurisdiction and gave Georgia almost a year in which to appear and contest the case on the merits in order to avoid entry of a default judgment. ${ }^{216}$ The nature of this order is a strong indication that the majority only reached and decided the threshold issue of jurisdiction. Issues of law applicable to the merits of the claim were reserved for Georgia's hoped-for appearance. ${ }^{\mathbf{2 1}}$ Thus, it is incor-

${ }^{213}$ These were terms of art. Local law encompassed a state's legislation and judicial decisions that established principles deviant from the common law. Certain subjects, like real property, were presumptively local. Federal law included the Constitution, treaties, and federal statutes, and there was debate over whether it also included the common law. See St. George Tucker, 1 Blackstone's Commentaries at 379-80 (cited in note 135) (noting that Justices Oliver Ellsworth and Bushrod Washington considered the common law to be federal law, and arguing against their position since it would remove all limits to federal jurisdiction). Common law was the non-statutory decisional law common to all of the states. It was of general applicability and transcended state borders, although it was not considered federal law. Though interstitial, it was "ready to pour in at every opening it could find." Peter Stephen DuPonceau, A Dissertation on the Nature and Extent of the Jurisdiction of the Courts of the United States 88 (Small, 1824, reprinted Arno, 1972).

214 Judiciary Act of 1789, ch 20, § 34, 1 Stat 73, 92. Professor Fletcher has argued persuasively that \$ 34 required that federal courts look to "local" statutory or common law in cases where it applied. See William A. Fletcher, The General Common Law and Section 34 of the Judiciary Act of 1789: The Example of Marine Insurance, $97 \mathrm{Harv} L \mathrm{Rev} 1513,1527$. 38 (1984). This lex loci principle applied to matters of a peculiarly local concern, such as title to real property, id at 1527-28, 1536-38, and where a state had established a local law deviant from the general common law, either by statute or judicial decision. Id at 1531-36. Section 34 not only contemplated the displacement of local law by federal statutory law, it implicitly recognized that in cases where neither federal nor local law applied, federal courts were free to apply a general, trans-state, common law. Id at 1516-27.

${ }^{215}$ It is also possible that all of the justices simply assumed that, once Georgia's sovereign immunity was swept away, liability under general common law would automatically follow. This is Professor Fletcher's position. See Fletcher, 35 Stan L Rev at 1070-71 (cited in note 2). The Court's actual judgment in Chisholm renders this possibility unlikely. See text at notes 216-17.

${ }^{218}$ Chisholm, 2 US (2 Dall) at 479.

${ }^{227}$ Justice Blair evidently felt that the Court need do no more than decide the jurisdictional issue, for in dismissing the argument that $\$ 14$ of the Judiciary Act failed to provide a mode of enforcement of a judgment against a state, Blair noted that "this argument takes it for granted, that the judgment of the court will be against the state; it possibly may be in favor of the state. ..." Id at 452. Judgment against Georgia "by default, in the present stage 
rect to contend, as the revisionists do, that Chisholm displaced "the prevailing state common law of government immunity [with a federal common law of state liability] . . . in a case presenting no question of substantive federal law." ${ }^{218}$ As will be seen, this view is the linchpin of revisionist theory. In fact, Chisholm decided only that there was no constitutional jurisdictional barrier to the federal courts hearing claims made against a state by a citizen of another state. The issue of whether local law or general common law might operate as the rule of decision on the merits and insulate the state from liability was reserved for another day. That day never came, for Georgia remained obdurate and the Eleventh Amendment prevented further development of the principles in question.

For the majority, the jurisdictional issue was relatively easy. It was enough for Justice Blair that the federal courts had been given the power to hear "controversies between a state and citizens of another state."219 The Constitution was supreme, and Article III's grant of authority was plain. To the argument that the clause was intended only to create federal jurisdiction when the state was a plaintiff, Blair responded that it was still a controversy between the named parties, no matter what status the state happened to occupy: "A dispute between A. and B. is surely a dispute between B. and A.",220

The issue for Justice Wilson was no less grave than whether

of the business ... would be too precipitate in any case, and too incompatible with the dignity of a state in this." Id at 452-53. Accordingly, Blair proposed that the Court issue the order it did. Justice Cushing adopted Randolph's argument, viewing Georgia's liability in assumpsit as a matter of capacity: "assumpsit will lie ...; ; provided a state is capable of contracting." Id at 469. Given the Court's order, Cushing's view is dictum and, in any case, it could be interpreted to mean that, if Georgia law controlled and immunized the state from liability in assumpsit, it did so by rendering the state incapable of contracting. Arguing from "general principles of right and equality," Justice Wilson offered similar dictum that "a state, for the breach of a contract, may be liable in damages." Id at 456, 465. Chief Justice Jay thought "a state is suable by citizens of another state; [but] . . such suability may nevertheless not extend to all the demands, and to every kind of action; there may be exceptions." Id at 479. Whether Jay meant these exceptions to be jurisdictional, or rooted in the so-called Rules of Decision Act, is not at all clear. What is clear is that the majority justices focused their argument on the jurisdictional issue and dealt hardly at all with the secondary issue of the controlling substantive law. This focus, coupled with the Court's dispositional order, makes clear that jurisdiction, not substantive liability in assumpsit, concerned the majority.

216 Amar, 96 Yale I J at 1474 (cited in note 2) (emphasis omitted). See also Atascadero, 473 US at 262-63, and at 289 (Brennan dissenting); Field, $126 \mathrm{U} \mathrm{Pa} \mathrm{L} \mathrm{Rev} \mathrm{at} 541$ (cited in note 2); Fletcher, $35 \mathrm{Stan} L \mathrm{Rev}$ at $1056-58$ (cited in note 2).

219 Chisholm, 2 US (2 Dall) at 450.

220 Id. 
"the People of the United States form a Nation?"221 To answer this momentous inquiry, Wilson turned first to political theory. Wilson declared governments to be "inferior contrivance[s] of man"222 and so were to "be considered as subordinate to the People." ${ }^{223}$ A state was a mere artificial person, "a complete body of free persons united together for their common benefit, to enjoy peaceably what is their own, and to do justice to others."224 Like its constituents, a state could "acquire property . . . [,] incur debts . . .[, and] be bound by contracts."225 Sovereignty provided no escape from the legal obligations created by such arrangements, for Wilson considered the sovereign's immunity from suit a despotic notion unfit for post-revolutionary America. ${ }^{226}$ Nor had Georgia retained immunity from suit as part of its residual sovereignty, for as to the purposes of the Union, Georgia had handed its sovereignty to the national government. The key, then, was "[w]hether the judicial decision of this cause is, or is not, one of those purposes."227 Wilson evidently meant this question to encompass two inquiries: whether the people had the power to give the federal courts jurisdiction over states, and whether they had actually done so. In the end, Wilson had little difficulty finding the power, and even less in finding its tangible expression in the literal language of Article III. ${ }^{228}$

After Justice Cushing offered a short literalist reprise of Blair in his opinion, Chief Justice Jay delivered the final opinion. Jay first sought to describe the sovereignty possessed by the states of the federal Union. He invoked the notion that sovereignty had passed from the Crown to the people of the United States at the time of the Revolution, ${ }^{229}$ and that, in 1787, "the people acting as

\footnotetext{
${ }^{221}$ Id at 453.

222 Id at 455.

${ }^{223}$ Id.

224 Id.

225 Id.
}

${ }^{228}$ For Wilson, the proof of this assertion was that "[i]n one sense the term sovereign has for its correlative, subject. . . [and under the] Constitution there are citizens, but no subjects." Id at 456 (emphasis in original). In his law lectures Wilson declared that "[i]n controversies, to which the state or nation is a party, the state or nation itself ought to be amenable before the judicial powers." 2 The Works of James Wilson 497 (1967) (cited in note 156). For further analysis of Wilson's view's on sovereignty, see text at notes 156-58. Wilson also thought that a repudiation of federal sovereign immunity was embodied in Article III's declaration that the judicial power extends "to controversies to which the United States are a party." Id. In this, he differed from Chief Justice Jay. See text at notes 234-36.

${ }^{227}$ Chisholm, 2 US (2 Dall) at 457.

${ }^{228}$ Id at 461-66.

229 Id at 470 . 
sovereigns . . . establish[ed] a constitution by which it was their will, that the state governments should be bound."230 Clearly then, to the extent constitutional authority had been given the federal courts to entertain suits against states, the states were bound by the grant.

Jay next concluded that there was nothing incompatible between state sovereignty and state susceptibility to suit. His argument centered on the artificiality of state personhood, and echoed Wilson's contention that states were assemblages of free persons. For Jay, it was enough to remark upon the absurdity of a rule that would subject the forty thousand citizens of Philadelphia to suit in their municipal capacity while immunizing their fifty thousand neighbors in Delaware simply because their representative agency was styled a state. ${ }^{231}$

Jay's final concern was with the Constitution itself. He concluded initially that its design was one for national union, and that the jurisdictional heads of Article III were a tangible expression of that design. Jay found the jurisdictional grant in the state-citizen diversity clause to be plain on its face, ${ }^{232}$ warranted by sound policy ${ }^{233}$ and necessitated by the constitutional design. For to read Article III as immunizing states from suit

would contradict and do violence to the great and leading principles of a free and equal national government, one of the great objects of which is, to ensure justice to all: To the few against the many, as well as to the many against the few. It would be strange, indeed, that the joint and equal sovereigns

230 Id at 471.

231 Id at $472-73$. See also note 178.

232 Discussing the clause, Jay observed:

If the Constitution really meant to extend these powers only to those controversies in which a state might be plaintiff, to the exclusion of those in which citizens had demands against a state, it is inconceivable that it should have attempted to convey that Id at 476 .

meaning in words, not only so incompetent, but also repugnant to it. . . .

23s

[B]ecause in case a state (that is, all the citizens of it) has demands against some citizens of another state, it is better that she should prosecute their demands in a national court, than in a court of the state in which those citizens belong; the danger of irritation and criminations arising from apprehensions and suspicions of partiality, being thereby obviated. Because, in cases where some citizens of one state have demands against all the citizens of another state, the cause of liberty and the rights of men forbid, that the latter should be the sole Judges of the justice due to the latter; and true republican government requires that free and equal citizens should have free, fair and equal justice."

Id at $475-76$. 
of this country, should, in the very Constitution by which they professed to establish justice, so far deviate from the plain path of equality and impartiality, as to give to the collective citizens of one state, a right of suing individual citizens of another state, and yet deny to those citizens a right of suing them. ${ }^{234}$

Even so, Jay conceded that the national government was probably immune from suit without its consent because "in cases of actions against the United States, there is no power which the courts can call to their aid."238 Thus, Article III's grant of jurisdiction over controversies to which the United States is a party carried with it an implied prudential exception not contained in the similar clause conferring jurisdiction over diverse state-citizen controversies. But that exception was one born of sheer practical necessity, a consideration not as pressing with respect to claims framed against states. ${ }^{236}$

It is an axiom of both conventional and revisionist Eleventh Amendment doctrine that the amendment implicitly incorporated Justice Iredell's dissent. ${ }^{237}$ Whatever the merits of the axiom, the rival camps remain in fundamental disagreement over the rationale of Iredell's opinion ${ }^{238}$ and, for that reason, this opinion must be scrutinized with particular care.

Iredell began by informing his audience, seated on backless benches in the small high-ceilinged chamber, that he conceived the issue before the Court to be whether "an action of assumpsit [will] lie against a state?" It was not, he asserted, the larger and more general question of " $[w]$ hether, a State can in any instance be

234 Id at 477 .

${ }^{235}$ Id at 478 (emphasis added).

238 See Jaffe, 77 Harv L Rev at 3 (cited in note 136) (discussing Maitland's view of English sovereign immunity. Maitland believed that it would be logically inconsistent for a lord to issue a writ against himself in his own courts and that "this is true of every petty lord in every petty manor; that there happens to be in this world no court above [the king's] court is, we may say, an accident." Jay seems to adopt a logic similar to Maitland: the United States cannot be sued in federal courts merely because of the "accident" that there is no higher authority to enforce the judgment.)

${ }^{237}$ For the conventionalists, see Hans $v$ Louisiana, 134 US 1, 12-19 (1890). For the revisionists, see Amar, 96 Yale L J at 1482 (cited in note 2); Fletcher, 35 Stan L Rev at 1077 (cited in note 2); Field, $126 \mathrm{U} \mathrm{Pa} \mathrm{L} \mathrm{Rev} \mathrm{at} \mathrm{541-43} \mathrm{(cited} \mathrm{in} \mathrm{note} \mathrm{2);} \mathrm{Welch,} 107 \mathrm{~S} \mathrm{Ct}$ at 2966 (1987) (Brennan dissenting).

${ }^{238}$ Compare Welch, $107 \mathrm{~S} \mathrm{Ct}$ at 2951 n 16 (1987) (Powell for the Court) (emphasizing Iredell's constitutional objections to suits against states) with id at 2966-68 (Brennan dissenting) (emphasizing Iredell's discussion of a lack of federal legislation to abrogate, in a diverse party suit, a state's common law sovereign immunity). 
sued?" sit against a state, "it must be in virtue of the constitution of the United States, and of some law of congress conformable thereto."240 Since Article III vested the Court with jurisdiction over controversies between a state and citizens of another state, the immediate constitutional hurdle was surmounted. ${ }^{241}$

Section 13 of the Judiciary Act gave the Court original but not exclusive jurisdiction "of all controversies of a civil nature . . . between a State and citizens of other States." this statutory grant as co-extensive with the limits of Article III extending jurisdiction to all such "controversies," the interpretation of the statutory language was transformed into the constitutional question of "[w]hat controversy of a civil nature can be maintained against a State by an individual [under the grant of jurisdiction in Article III]?"243 Either the framers meant "to refer to antecedent laws" for the answer, or they meant "[t]o enable congress ... to pass all such laws as they might deem necessary and proper to carry the purposes of this Constitution into full effect ...."244 Iredell never clearly answered this question, for he immediately turned back to interpreting the Judiciary Act. Thus, Iredell's opinion ultimately rested on statutory grounds, although at the very end of his opinion he did intimate that Congress might not be able to authorize suit against a state. ${ }^{245}$

Iredell focused the remainder of his opinion on $\S 14$ of the Judiciary Act, which empowered the federal courts to issue all writs "agreeable to the principles and usages of law."246 Either this phrase referred to "1st. Those of the particular laws of the state, against which the suit is brought. Or $2 \mathrm{~d}$. Principles of law common to all the states."247 By "particular laws" Iredell meant local law, particularly legislation, existing at the time the Judiciary Act was passed. In dismissing this leg of the inquiry, he noted that neither in Georgia nor in any other state was there:

2s9 Chisholm, 2 US (2 Dall) at 430.

210 Id.

241 "The Constitution ... provides ... jurisdiction ... [over] [c]ontroversies between a state, and foreign states, citizens or subjects." Id at 431.

242 Judiciary Act of 1789 , ch $20, \S 13,1$ Stat 73, 80 .

${ }^{243}$ Chisholm, 2 US (2 Dall) at 432.

24 Id.

${ }^{243}$ See text at notes 263.

${ }^{248}$ Judiciary Act of $1789, \operatorname{ch~} 20, \S 14,1$ Stat 73,82 , quoted in Chisholm, 2 US (2 Dall) at 434 .

${ }^{247}$ Chisholm, 2 US (2 Dall) at 434. 
any particular legislative mode, authorizing a compulsory suit for the recovery of money against a State, . . . either when the Constitution was adopted, or at the time the judicial act was passed. Since that time an act of assembly for such a purpose has been passed in Georgia. But that surely could have no influence in the construction of an act of the legislature of the United States, passed before.

The only principles of law, then, that can be regarded, are those common to all the states. ${ }^{248}$

Before continuing with the thread of Iredell's thought, consider the implications of this passage to the revisionist theme. Some revisionists contend that Iredell simply foreshadowed Erie by referring, in a diverse party case, to antecedent state law as the rule of decision. ${ }^{249}$ But Iredell both dismissed the relevance of a Georgia statute that contravened its common law immunity and embraced a trans-state common law as the rule of decision. ${ }^{250}$ If he was truly looking to state law as the rule of decision in a diverse party case, Iredell would have done neither of these things. Instead, he construed a federal statutory reference to the "principles and usages of law" as incorporating either local law or general common law. Moreover, in ascertaining local law, Iredell looked to local state law as it existed when the Constitution and Judiciary Act of 1789 were adopted. This static view seems at odds with the language in $\S 34$ of the Judiciary Act and is, of course, quite different from modern Erie doctrine. Iredell evidently was not looking to local state law; rather, he read federal law as incorporating local state law at the time of its enactment. Thus, Iredell's rule of decision was a federal one, given content either by local state law at a moment frozen in time or by a general trans-state common law. ${ }^{251}$

So directed, Iredell focused his inquiry on whether, prior to constitutional union, a Chisholm-like action could have been main-

248 Id at 434-35.

${ }^{249}$ See Amar, 96 Yale L J at 1472 (cited in note 2); Welch, $107 \mathrm{~S}$ Ct at 2966-68 (1987) (Brennan dissenting).

${ }^{250}$ There was nothing unusual about Iredell's willingness to refer to a common law general to all of the states as the rule of decision. This practice was extremely common in the early federal courts, long before the rule of Swift v Tyson, 41 US (16 Pet) 1 (1842). See generally Fletcher, 97 Harv L Rev 1513 (cited in note 214).

${ }^{281}$ Chisholm, 2 US (2 Dall) at 435-37. A similar approach was explicitly embedded in the federal Process Acts of 1789 and 1792, which provided that the federal courts were to follow the rules of procedure "as are now used or allowed in the [state] supreme courts." Act of Sept. 29, 1789, ch 21, § 2, 1 Stat 93, and Act of May 8, 1792, ch 36, § 2, I Stat 275, 276 (emphasis added). See Charles A. Wright, The Law of Federal Courts $\$ 61$ (West, 4th ed 1983). 
tained against a state under the general common law. "If it could, . . . it is now maintainable here: [i]f it could not, . . . it is not maintainable. ..."252 This formulation demanded a lengthy excursion into the English common law of state immunity. Since there was no provision under the common law for suit against the Crown except by its consent, Iredell concluded that the Judiciary Act's reference to "principles and usages of law" was simply inadequate to vest in the federal courts jurisdiction of a private claim against a sovereign state. ${ }^{253}$

Of course Iredell deliberately did not consider the question of whether the Court's federal question jurisdiction would render a state susceptible to suit in federal court; as a diverse party case, Chisholm required no such inquiry. The revisionists contend, nevertheless, that Iredell left distinct hints of his view that state sovereignty was surrendered in such instances. They rely primarily on the following passage:

The powers of the general Government, either of a Legislative or Executive nature ... do for the most part ... affect individuals, and not states: they require no aid from State authority. . . . The judicial power is of a peculiar kind. It is indeed commensurate with the ordinary legislative and executive powers of the general government. . . But it also goes further. Where certain parties are concerned, although the subject in controversy does not relate to any of the special objects of authority of the general government, wherein the separate sovereignties of the States are blended in one common mass of supremacy, yet the general government has a judicial authority in regard to such subjects of controversy, and the legislature of the United States may pass all laws necessary to give such judicial authority its proper effect. ${ }^{254}$

${ }^{252}$ Chisholm, 2 US (2 Dall) at 437.

$28 s$ Id at $435-46$.

${ }^{234}$ Id at 435-36. The revisionists also rely on Iredell's off-hand observation that the "authorities of the general government ... are full and discretionary, within the restrictions of the Constitution itself." Id at 432. The revisionists deduce an implicit corollary from this statement that the federal judicial power pertaining to these authorities is similarly unfettered. This corollary was certainly correct with respect to the original Constitution, but it need not be true after the Eleventh Amendment expressly narrowed federal judicial power. The amendment might well have made the federal judicial power less extensive than the federal legislative power. That, of course, is a radical departure from Federalist principles: "If there are such things as political axioms, the propriety of the judicial power of a government being co-extensive with its legislative may be ranked among its number." The Federalist 80 (Hamilton), in Federalist Papers at 475, 476 (cited in note 156). Whether this was, in fact, the intention of the Eleventh Amendment will be considered in text at notes 260-98. 
From this some revisionists divine the conclusion that Iredell saw state immunity as coextensive with its lawmaking capacity. For example, Professor Amar reads this passage as concluding that "[a] state could use its lawmaking power to adopt rules immunizing itself from liability, as long as such immunity frustrated no higher-law restrictions on the state's limited sovereignty."255 Such higher-law restrictions were to be found in federal question jurisdiction, one "of the special objects of authority of the general Government, wherein the separate sovereignties of the States are blended in one common mass of supremacy.,"256 There are two problems with this reading of Iredell. First, even if accurate, it is dictum of the most oblique sort. Second, it wholly ignores Iredell's final and express statement about the constitutional status of state immunity from suit. Iredell assured his audience that his "present opinion [was] strongly against any construction of [the Constitution], which will admit, under any circumstances, a compulsive suit against a state for the recovery of money."257

While Iredell left few clues as to the nature of his perceived constitutional impediment to suits against states, it is possible to hazard a reconstruction of his objection. Iredell regarded the states as islands of sovereignty:

Every state in the Union, in every instance where its sovereignty has not been delegated to the United States, I consider to be as completely sovereign, as the United States are in respect to the powers surrendered. The United States are sovereign as to all the powers of government actually surrendered: each state in the Union is sovereign, as to all the powers reserved. It must necessarily be so, because the United States have no claim to any authority but such as the states have surrendered to them: of course the part not surrendered must remain as it did before. ${ }^{258}$

While in ratifying the Constitution the states had surrendered sovereignty to the extent of the powers delegated to Congress and the express prohibitions placed on state power, Iredell must have

${ }^{285}$ Amar, 96 Yale L J at 1472 (cited in note 2).

258 Chisholm, 2 US (2 Dall) at 435.

${ }^{257}$ Id at 449 . Iredell was also undoubtedly aware of the passions the majority's judgment would produce, for he concluded, "I pray to God, that if the Attorney General's doctrine, as to the law, be established by the judgment of this Court, all the good he predicts from it may take place, and none of the evils with which, I have the concern to say, it appears to me to be pregnant." Id at 450 .

${ }^{28 s}$ Id at 435. 
thought that an action for money against a state could never validly be created pursuant to those delegated powers, nor could a state be held so accountable for attempting to exercise a prohibited power. ${ }^{259}$ Under Iredell's reasoning, either the judicial power of Article III carried an implicit limitation or the Tenth Amendment had independent normative content. Iredell did not tell us; we can only guess.

\section{B. Proposal and Ratification of the Amendment}

Reaction to Chisholm was fierce. Georgia's House of Representatives passed legislation declaring that any attempt to levy judgment upon Georgia on behalf of Alexander Chisholm was a felony with a punishment of "death, without the benefit of the clergy, by being hanged."260 Georgia also called for a constitutional amendment to reverse Chisholm ${ }^{281}$ and, in this, was joined by Virginia and Massachusetts. ${ }^{262}$ These demands had already been anticipated, for resolutions proposing a constitutional amendment to reverse Chisholm had been introduced within days of the decision itself. From the speed of the initial reaction, one might surmise that the holding in Chisholm had, indeed, violated an original understanding of state immunity from suit in the federal courts. Such an explanation is deceptively simple, for it took more than a year and two sessions of Congress before the Eleventh Amendment was sent to the states for ratification. ${ }^{263}$

Moreover, the legislative history suggests that Congress did not regard the amendment as a blanket grant of immunity. Representative Sedgwick of Massachusetts made the initial proposal in the House on February 19, 1793, the day after the Chisholm decision:

[T]hat no State shall be liable to be made a party defendant

250 Iredell's views apparently applied with equal force to suits for money brought against states by either private citizens or the United States. In dictum Iredell asserts flatly that the Constitution forbids "under any circumstances, a compulsive suit against a state for the recovery of money." Id at 449 (emphasis added). Iredell's careful limitation of this immunity principle to suits for money leaves open the possibility of equitable remedies against the states for their constitutional violations. Such injunctive relief is necessary to implement the Supremacy Clause and has traditionally been cast in the nominal form of suits against officers. See Osborn v Bank of the United States, 22 US (9 Wheat) 738 (1824); Ex parte Young, 209 US 123 (1908).

${ }^{280}$ Augusta Chronicle (Nov 23, 1793), reporting legislative action of Nov 19, 1793, quoted in Jacobs, Sovereign Immunity at 56-57 (cited in note 2).

201 Jacobs, Sovereign Immunity at 56 (cited in note 2).

${ }^{262}$ Id at 57-60. See note 279 and accompanying text.

${ }^{283}$ See 4 Annals of Congress 30-31, 476-77 (1794). 
in any of the Judicial Courts established or to be established under the authority of the United States at the suit of any person or persons, citizens or foreigners, or of any body politic or corporate whether within or without the United States. ${ }^{264}$

This was unvarnished state sovereign immunity in the federal courts. If this proposal had been adopted, modern Eleventh Amendment doctrine would make sense. ${ }^{265}$ At the very least, the presence of the proposal is a vivid reminder that the Eleventh Amendment's framers considered and apparently rejected a broad constitutional immunity.

On the day after Sedgwick's proposal, an unknown senator introduced a resolution in the Senate proposing the following constitutional amendment:

The Judicial power of the United States shall not extend to any suits in law or equity, comrnenced or prosecuted against one of the United States by citi: ss of another State, or by citizens or subjects of any foreign State. ${ }^{266}$

If this proposal had been intended to confer sovereign immunity

${ }^{264}$ Charles Warren, 1 The Supreme Court in United States History 101 (Little, Brown, 1922). There is some dispute as to whether this resolution was actually introduced. Professor Nowak contends that Representative Sedgwick introduced a resolution for a constitutional amendment that would have prohibited the federal courts from entertaining suits against states by "any person or persons whether a citizen or citizens, or a foreigner or foreigners, of any body politic or corporate, whether within or without the United States." Nowak, 75 Colum L Rev at 1436 (cited in note 2), quoting Pennsylvania Journal (Feb 20, 1793). Charles Warren also insisted that such a resolution was introduced, although he quoted it slightly differently and did not attribute it to Sedgwick. The resolution quoted by Warren without source citation was identified by Professor Fletcher as from a contemporary newspaper. See $\mathrm{Pa} \mathrm{J} \&$ Weekly Advertiser, Feb 27, 1793 at 1, col 2, quoted in Fletcher, 35 Stan L Rev at 1058-59 (cited in note 2). Judge Gibbons contends that "[t]he existence of such a resolution . . . appears dubious." Gibbons, 83 Colum $L$ Rev at $1926 \mathrm{n} 186$ (cited in note 2). Gibbons bases his conclusion on the absence of any such resolution in either the Annals of Congress or the National Archives. Id. The existence of two contemporary newspaper accounts of the resolution and its absence from the official records of the Congress may suggest that the resolution was prepared but never formally introduced. Perhaps Representative Sedgwick told the press he had introduced such a resolution when actually he had failed to do so. Perhaps Sedgwick delivered remarks on the floor of the House that were not in the form of a resolution and that went unrecorded in the Annals of Congress. However, it is at least equally likely that Sedgwick did precisely what the newspapers reported, and that the event went wholly unrecorded. See, for example, James H. Hutson, The Creation of the Constitution: The Integrity of the Documentary Record, $65 \mathrm{Tex} \mathrm{L}$ Rev 1, 35-38 (1986).

${ }^{285}$ Indeed, this proposal would be even more stringent than current Eleventh Amendment law. For example, the United States would be prohibited from suing the states, and the states would not be able to sue each other in the Supreme Court.

${ }^{286} 3$ Annals of Congress 651-52 (1793) (emphasis added). 
upon the states by a general denial of federal jurisdiction over suits against states, it would have excluded the italicized phrase. ${ }^{267}$ Since it did not, the final phrase must have been intended to have some meaning. The revisionists contend that the phrase was included in order to limit Article III's "specific grants of party status jurisdiction, not its grant of subject matter jurisdiction."268 But it is at least as likely that the phrase was intended to provide a party status basis for denial of jurisdiction. Support for this view may be found in the historical evidence surrounding the Eleventh Amendment's adoption.

The amendment was a product of Federalist political prudence and congressional compromise. The Federalists were concerned about rising Republican clamor in the states for a new constitutional convention to advance extreme states' rights positions. ${ }^{269}$ Moreover, such a convention was seen as fertile ground for attempts by the French revolutionary government to inveigle America into overt support for France in its war against Great Britain, Holland, and Spain. ${ }^{270}$ To avoid the calamity of a convention, the Federalists conceded the Eleventh Amendment.

The Federalists may have had other motivations for supporting the amendment. They may have been simply bowing to popular anti-British sentiment; ${ }^{271}$ they may have regarded the amendment as an effective device for limiting John Jay's room to negotiate a final treaty settling the British debt issues; ${ }^{272}$ or they may have thought that the amendment was "more formal than real," for important constitutional prohibitions upon states could be enforced without the necessity of joining states as defendants. ${ }^{273}$ Finally, the Federalists might have foreseen that some later Court would construe the amendment as merely stripping the federal courts of original jurisdiction over suits against states brought by foreign citizens. ${ }^{274}$ The British creditor who might lose in an American state court could still present the federal question of his

${ }^{267}$ New York's ratification convention had proposed just such a general jurisdictional denial: "[N]othing in the Constitution . . . is to be construed to authorize any suit to be brought against any state, in any manner whatever." 2 Elliot's Debates at 409 (cited in note 165).

${ }^{268}$ Gibbons, 83 Colum L Rev at 1927 (emphasis omitted) (cited in note 2).

268 Id at 1930-32.

270 Id at 1928-30.

${ }^{271}$ See Nowak, 75 Colum L Rev at 1438-40 (cited in note 2).

${ }^{272}$ See Forrest McDonald, The Presidency of George Washington 144 (U Kan, 1974).

273 Jacobs, Sovereign Immunity at 74 (cited in note 2).

274 See, for example, Worcester $v$ Georgia, 31 US (6 Pet) 515 (1832). See also text at notes $330-35$. 
treaty rights before the Supreme Court for appellate review. ${ }^{275}$ Whatever other rationales the Federalists may have had for their support, the amendment did serve its immediate political purpose since its enactment successfully defused calls for a new constitutional convention.

Even though the "roster of those favoring the amendment includes the names of ardent nationalists, as well as states' rights men," ${ }^{278}$ it is a fair inference that its proponents intended it to deprive the federal courts of jurisdiction over federal question claims whenever the plaintiff was a foreigner or citizen of another state. This conclusion is supported by the following historical evidence.

First, Senator Gallatin proposed an amended version of the Eleventh Amendment that would have permitted suits against states by foreigners and citizens of other states, to the extent that their claims arose under a federal treaty. ${ }^{277}$ Gallatin was evidently concerned that such treaty claims might be foreclosed by the proposed amendment. But his proposal was overwhelmingly defeated because it would have permitted precisely the kind of action that debtor states wished to eliminate. ${ }^{278}$ Presumably, Gallatin's opponents thought that the unamended version would have the desired effect of preventing the federal courts from hearing such federal claims.

The states that were most ardent in advocating the amendment-Massachusetts, Virginia, and Georgia-all faced pending claims in the Supreme Court that posed issues turning upon interpretation of the Constitution or federal treaties. ${ }^{279}$ After ratifica-

275 Even more important, from a practical standpoint of a British creditor, was the federal government's assumption of the major portion of the state debts. This, of course, eliminated the necessity of suit against a balky state debtor. See Jacobs, Sovereign Immunity at 69 (cited in note 2).

${ }^{276} \mathrm{Id}$ at 71.

${ }^{277}$ Gallatin's proposed amendment read as follows:

The Judicial power of the United States, except in cases arising under treaties made under the authority of the United States, shall not be construed to extend to any suit in law or equity, commenced or prosecuted against one of the United States, by citizens of another State, or by citizens or subjects of any foreign State.

4 Annals of Congress 30 (1794) (emphasis added).

${ }^{273}$ See Gibbons, 83 Colum L Rev at 1930-34, 1936 (cited in note 2).

${ }^{279}$ Virginia faced claims of over a million dollars from shareholders of the Indiana Company, who asserted that Virginia had unlawfully seized land conveyed to them while Virginia was still a colony. Hollingsworth $v$ Virginia, 3 US (3 Dall) 378 (1798) and discussion of the litigation in Jacobs, Sovereign Immunity at 57-60, 94 (cited in note 2). Georgia faced a constitutional challenge, under the contracts clause, to its alteration of the terms of an installment sale of land from the state to the South Carolina Yazoo Company. Moultrie $v$ 
tion of the amendment, the Supreme Court dismissed all such pending claims on the grounds that the Eleventh Amendment deprived the Court of jurisdiction. ${ }^{280}$ If the amendment had been intended merely to prune two twigs from Article III's diverse party jurisdictional tree, the Court's dismissal simply would have placed these claims in hibernation. For were Congress to act to confer upon the federal courts original jurisdiction of claims arising under the Constitution, treaties, or federal statutes, all of these claims (or others very much like them) would emerge from their slumbers and reassert themselves in federal courts. This was not merely idle speculation, for only three years later Congress did just that. ${ }^{281}$ It strains credulity to suppose that Massachusetts, Virginia, and Georgia, the chief architects of the amendment, would be so oblivious to their interests as to leave this possibility alive.

Moreover, those who construe the amendment as only a narrow limitation upon Article III's diversity jurisdiction are required to amend its text in order to deliver their desired meaning. In revisionist parlance, the Eleventh Amendment reads:

The Judicial power of the United States shall not be construed to extend to any suit in law or equity founded upon a diverse party head of jurisdiction, commenced or prosecuted against one of the United States by Citizens of another State, or by Citizens or Subjects of any Foreign State.

Those who read the amendment as a complete party-based ouster of federal jurisdiction are comfortable with the unaltered text.

Finally, if the point of the amendment was simply to overturn Chisholm's jurisdictional holding, and strip the federal courts of

Georgia, a largely unreported case discussed in Jacobs, Sovereign Immunity at 63-64 n 83, 94 (cited in note 2). Massachusetts was named defendant in a suit challenging its confiscation of loyalist property in violation of the peace treaty. Vassal v Massachusetts, an unreported case on the docket of the Supreme Court, discussed in Jacobs, Sovereign Immunity at 60-62 n 72, 94 (cited in note 2). All three of these actions had been brought as original proceedings in the Supreme Court, apparently on the strength of the state-citizen diversity clause and $\S 13$ of the 1789 Judiciary Act.

${ }^{280}$ See Hollingsworth $v$ Virginia, 3 US ( 3 Dall) 378 (1798). The Court could not have retained jurisdiction on federal question grounds because, under Article III, it lacked original jurisdiction in such actions. Moreover, the suit could not be brought in any other federal forum because the 1789 Judiciary Act failed to vest original federal question jurisdiction in the lower federal courts. Congress first created federal question jurisdiction in the short lived Judiciary Act of 1801. See Act of Feb 13, 1801, ch 4, 2 Stat 89, repealed by Act of March 8, 1802, ch 8, 2 Stat 132. The first lasting grant of a general federal question jurisdiction occurred in 1875. See Act of March 3, 1875, ch 137, 18 Stat 470.

${ }^{281}$ See Act of Feb. 13, 1801, ch 4, 2 Stat 89, repealed by Act of March 8, 1802, ch 8, 2 Stat 132. 
the power to hear diverse state-party claims brought against states, a constitutional amendment was unnecessary. The task could have been neatly accomplished by amending $\S 13$ of the Judiciary Act to deprive the federal courts of such party-based jurisdiction.

The self-executing and irreducible nature of the Court's original jurisdiction ${ }^{282}$ does not undercut this conclusion. At the time, there was no certainty on this point. In Chisholm itself, Justice Iredell argued unnecessarily that the Court's original jurisdiction was not self executing. ${ }^{283}$ In Federalist 81, Hamilton noted that the Court's jurisdiction included "cases in which a state might happen to be a party." ${ }^{284}$ By contrast, in Federalist 80, after a summary of the heads of federal jurisdiction (including state-party suits) Hamilton concluded, without distinguishing between the Court's original and appellate jurisdiction, that "the national legislature will have ample authority to make such exceptions and to prescribe such regulations as will be calculated to obviate or remove ... inconvenience[]."285 If the self-executing nature of the Court's original jurisdiction over state-party cases had been beyond cavil, the First Congress would likely have felt it unnecessary to include such a jurisdictional grant in $\S 13$ of the 1789 Judiciary Act. ${ }^{286}$ Moreover, the Judiciary Act itself only implemented part of the Supreme Court's original jurisdiction. ${ }^{287}$ Even today, when the self executing nature of the Court's original jurisdiction is settled, there is room to argue that the Court's original jurisdiction over state-party cases is not irreducible, but is subject to congressional

${ }^{282}$ See Kentucky v Dennison, 65 US (24 How) 66, 98 (1861).

${ }^{283} 2$ US (2 Dall) at 432 . Iredell's argument was unnecessary because $\$ 13$ of the 1789 Judiciary Act clearly provided the Court with original jurisdiction over suits "between a state and citizens of other states." Judiciary Act of 1789 , ch $20, \S 13,1$ Stat 73,80 . Perhaps for that reason, none of Iredell's brethren responded to his assertion. Additionally, Attorney General Randolph's argument in Chisholm assumed that the Supreme Court's original jurisdiction needed the enabling legislation of the 1789 Judiciary Act. See text at notes 207-09.

${ }^{284}$ Federalist 81 (Hamilton) in Federalist Papers at 481, 487 (cited in note 154).

${ }^{285}$ Federalist 80 (Hamilton) in Federalist Papers at 475, 481 (emphasis in original) (cited in note 154). While Hamilton was either disingenuous or confused about the operation of the Exceptions Clause, Professor Amar has provided an account of the Court's original jurisdiction over state-party cases that would permit congressional regulation of this jurisdiction under the Necessary and Proper Clause of Article I, § 8. See Akhil Reed Amar, A Neo-Federalist View of Article III: Separating the Two Tiers of Federal Jurisdiction, 65 BU L Rev 205, 254-55 n 160 (1985).

${ }^{288}$ See note 283.

${ }^{287}$ Judiciary Act of 1789 , ch $20, \S 13,1$ Stat 73,80 . See also Paul M. Bator, et al, Hart and Wechsler's The Federal Courts and the Federal System 33 (Foundation, 3d ed 1988) (noting that the statutory grant of original jurisdiction was "nearly but not exactly coextensive with the constitutional grant."). 
restriction. ${ }^{288}$

A constitutional amendment was desirable, however, for two reasons. First, Chisholm had aggressively established the outer boundaries of Article III jurisdiction by holding unequivocally that the federal judicial power encompassed suits against states by outof-staters. A mere statutory response would not permanently inter this disturbing precedent. Second, even Iredell had reserved judgment on whether state immunity from suit was abridged in suits founded on federal question jurisdiction. If immunity did not adhere to those cases, an act of Congress creating federal question jurisdiction would bring the states once again to the bar of the federal courts. To avoid this, a constitutional amendment was needed. The first attempted amendment, by Massachusetts Representative Sedgwick, sought directly to secure a blanket grant of state immunity. ${ }^{289}$ When that failed, a compromise was struck that focused on the class of plaintiffs that most troubled the states: foreign and domestic out-of-state creditors and expatriate loyalists seeking to recover their seized property. The compromise of the Eleventh Amendment manipulated jurisdiction awkwardly in order to create, in effect, a state immunity doctrine limited to a defined class of plaintiffs.

There is only one significant indication to the contrary. In the course of its congressional evolution, the first phrase of the amendment-the "judicial power shall not extend"-was replaced by the present language: "the judicial power shall not be construed to extend." This change has proved to be fertile ground for debate over its substantive effect. Adherents of the conventional view interpret the new language as confirming that the amendment was intended to reaffirm a general understanding of state immunity existing at the time Article III was adopted. ${ }^{290}$ Other scholars suggest that the phrase was intended to "ensure retrospective application of the amendment to suits already filed ... . [or] to soften any supposed

${ }^{238}$ Article III gives the Supreme Court original jurisdiction over "Cases . . . in which a State shall be a Party." US Const, Art III, § 2. Because of the long established principle that the only state-party cases within the Court's original jurisdiction are those specifically enumerated in Article III, $\S 2$-state:state, state:foreign state, state:out-of-state citizen, state:alien-it is possible to read this clause as a permissive grant of jurisdiction, requiring congressional action to effectuate and subject to congressional restrictions. See, for example, Cohens $v$ Virginia, 19 US (6 Wheat) 264, 398 (1821). Surprisingly, a leading revisionist-Professor Amar-embraces precisely this reading. See Amar, 65 BU L Rev at $254 \mathrm{n} 160$ (cited in note 285).

${ }^{289}$ See note 264 and accompanying text.

${ }^{290}$ Hans v Louisiana, 134 US 1, 9-19 (1890). See also Jacobs, Sovereign Immunity at 68 (cited in note 2). 
rebuke to the Court." ${ }^{\prime 291}$ The revisionist position is that the phrase was intended to make the amendment "conform to the framers' intent that the judicial power should not be construed to extend to the enumerated diverse party suits as such, but would extend to these diverse configurations whenever jurisdiction was independently based on another affirmative jurisdictional grant."292

Each interpretation is problematic. The conventional "reaffirmation" reading is belied by the demonstrable lack of original unanimity concerning state immunity. ${ }^{293}$ The revisionist reading derives its support from the language of a constitutional amendment first proposed by Senator John Breckenridge of Kentucky in 1805, which employed the same phrase to eliminate all diverse party jurisdiction but leave intact federal question jurisdiction. ${ }^{294}$ While it is anomalous to read the Breckenridge proposal as repealing some of the affirmative jurisdictional grants of Article III, and the identically phrased Eleventh Amendment as creating a new partybased jurisdictional bar, the peculiar political realities of the compromise embodied in the Eleventh Amendment seem to confirm the anomaly.

A related revisionist reading is that the language was simply an interpretive directive to the courts. According to Professor Fletcher, "[t]he amendment required that the [state- citizen diversity] clause be construed ... to authorize federal court jurisdiction only when the state was a plaintiff. In other words, the amendment required that the clause be read to mean precisely what Marshall

\footnotetext{
291 Jacobs, Sovereign Immunity at 68-69 (cited in note 2).

${ }^{292}$ Amar, 96 Yale L J at 1482 (cited in note 2) (emphasis in original, footnote omitted).

${ }^{293}$ See text at notes 133-85.

294 Breckenridge's proposed amendment provided that:
}

The judicial power of the United States shall not be construed to extend to controversies between a State and the citizens of another State; between citizens of different States, ... ; and between a State and the citizens thereof and foreign States, citizens, or subjects.

14 Annals of Cong 53 (1805). Senator Samuel Maclay of Pennsylvania introduced the same amendment the following year, 15 Annals of Cong 68 (1806), and Senator Henry Clay of Kentucky introduced a similar amendment in 1807. 16 Annals of Cong 76 (1807). Representative Elliot of Vermont introduced in the House a resolution of the Vermont legislature concurring with the "resolutions of the State of Kentucky, proposing an amendment to the Constitution of the United States, 'for confining the judiciary power of the . . . United States to cases ... arising under the Constitution and laws of the United States ... ; cases affecting Ambassadors ...; cases of admiralty ...; controversies to which the United States shall be a party; and to controversies between two or more States. ...'" Id at 216. Since the proposed amendment spoke only of the remaining three diverse party categories of Article III, $\S 2$, the Vermont resolution is a plain indication that, at very least, the Vermont legislature read language similar to that used in the Eleventh Amendment in the way the revisionists now urge. See Amar, 96 Yale $L J$ at 1482-83 n 233 (cited in note 2). 
and Madison had contended it meant during the Virginia ratifying convention." ${ }^{295}$ While this reading is possible, it fails to account for the clearly expressed desires of Massachusetts, Virginia, and Georgia to bar the federal courts from hearing federal question claims presented by out-of-staters. Following the Chisholm decision, the Anti-Federalists wanted far more than mere constitutional confirmation of Madison's and Marshall's representations; they wanted firm assurance that the federal courts would be permanently disabled from hearing claims presented by the disfavored classes of foreign creditors and expatriate loyalists. A narrowing construction of the state- citizen diversity clause would not suffice; the stronger medicine of jurisdictional ouster was needed to eliminate the possibility of such claims reappearing via the back door of federal question jurisdiction. Thus, despite slender indications to the contrary, the Eleventh Amendment was designed to cut a swath through all the jurisdictional grants of Article III.

Far less clear is whether the amendment was also intended to repudiate any implicit waiver of state sovereign immunity contained in the jurisdictional grants of Article III. If this more ambitious goal was contemplated, it is difficult to understand why it was not plainly stated, as Representative Sedgwick had initially proposed. ${ }^{298}$ Certainly the ratinication debates concerning the scope of Article III were fresh in the collective mind of the nation. If the Court's opinion in Chisholm embodied a wrong-headed understanding of Article III as containing an implicit waiver of sovereign immunity, one might have expected that the Eleventh Amendment would have explicitly reversed that core misunderstanding rather than simply carved out a broad, party-based head of jurisdictional prohibition. The resort to the latter method suggests either that the Eleventh Amendment was profoundly pragmatic or that its framers never regarded Chisholm as doing more than announcing pervasive federal jurisdiction over states, and leaving open the possibility that the Court might employ a rule of decision that could abrogate state common law immunity.

Pragmatically, Federalists supported the amendment as a necessary price to avoid a constitutional convention; debtor states supported it as a way to avoid their legitimate foreign obligations. There is very little aroma of principle in the entire affair; while the amendment reversed Chisholm it did so not on the broad ground

293 Fletcher, 35 Stan L Rev at 1061-62 (cited in note 2) (footnotes omitted). See also notes 167-68.

${ }^{208}$ See note 264. 
that Chisholm had articulated a fundamentally wrong principle-implicit waiver of sovereign immunity-but on the narrow and crass ground that Chisholm left the states financially exposed to claims by foreigners and citizens of other states. ${ }^{297}$

The more principled reading, which can coexist with the pragmatic view, is that the amendment's framers responded directly to the threat of Chisholm. If Chisholm announced a broad view of Article III diversity jurisdiction, the framers wished to foreclose the possibility that that jurisdiction might be used to devise rules of decision that could abrogate the states' common law immunity. While Congress could have accomplished much the same end by simply enacting a statute that expressly directed the federal courts to observe state common law immunity as the rule of decision in Chisholm-type suits, such a compromise would have still left the states open to the jurisdiction of an unfriendly forum in federal question cases and, moreover, it could be repealed by a future majority in Congress. A constitutional denial of jurisdiction was more certain and final, even if clumsy. Under this view, Congress used a meat cleaver to trim a legal callus. Predictably, it caught a little more flesh than was optimum.

\section{Early Interpretations of the Eleventh Amendment}

Few opportunities existed for interpretation of the new Eleventh Amendment because Jay's Treaty of $1794^{288}$ created an international commission to adjudicate the claims of British creditors and hence prevented further testing of the peace treaty in American courts. Those opportunities that did arise suggest that the Eleventh Amendment was not regarded as a fount of general immunity from suit but was, rather, an overriding party-based jurisdictional ouster cutting across the provisions of Article III. The

${ }^{297}$ In the absence of original federal question jurisdiction, a foreign' creditor's assignment of his treaty-based claim to a citizen of the defendant state, in order to circumvent the Eleventh Amendment's party-based jurisdictional ouster, would be futile. Even assuming the existence of federal question jurisdiction, the courts could have regarded $\S 11$ of the Judiciary Act as a two-edged sword. Section 11 deprived the circuit courts of diversity jurisdiction over suits brought by an assignee of a chose in action "unless a suit might have been prosecuted in such court . . . if no assignment had been made." 1 Stat at 79. Collusive attempts to defeat diversity of citizenship so as to escape the Eleventh Amendment's partybased withdrawal of jurisdiction might also have been precluded by $\S 11$. See, for example, the broader language in the modern analogue to $\S 11,28$ USC $\S 1359$ (1976), which divests the district courts from all jurisdiction when a "party, by assignment or otherwise, has been improperly or collusively ... joined to ... invoke jurisdiction." Compare New Hampshire $v$ Louisiana, 108 US 76 (1883) (discussed in text at notes 370-74).

${ }^{298}$ Treaty of Amity, Commerce and Navigation, Nov 19, 1794, 8 Stat 116. 
cases that presented the issue arose in several different contexts: admiralty, appeals under $\S 25$ of the 1789 Judiciary Act, litigation between the states themselves, and those vexing cases where claims were framed not against the state but against governmental officers, or where the state claimed an interest in the litigation though it was not a party.

\section{Admiralty: Peters, Bright, and Madrazo.}

In 1778, Gideon Olmstead, a citizen of Connecticut, and other American sailors who had been impressed into naval service aboard the British sloop Active mutinied and seized control of the vessel. On its way to an American port, the Active was captured by a Pennsylvania naval vessel. In the Pennsylvania admiralty court Olmstead and his confederates claimed exclusive rights to the $\mathrm{Ac}$ tive as a prize of war. Pennsylvania resisted Olmstead's claim and asserted an identical rival claim to the Active. Olmstead was awarded one-fourth of the Active's value. He promptly appealed the Pennsylvania court's decision to the Court of Appeals for prize cases, a committee of the Continental Congress, which reversed the prior award and sustained Olmstead's claim. Pennsylvania refused to comply; instead, it paid over the proceeds of sale of the Active to David Rittenhouse, the state treasurer.

By 1801, Rittenhouse was dead and Olmstead had renewed his claim in the new federal courts. The Rittenhouse heirs, conscious of the common law rule that an agent remained liable for all monies paid over to his principal if a rival claimant later defeated the principal's claim, refused Pennsylvania's demand for the proceeds held by them. In 1803, Philadelphia's federal trial judge, Richard Peters, ruled in favor of Olmstead. ${ }^{299}$ Pennsylvania reacted hysterically, adopting a legislative resolution declaring Peters's decree a nullity, directing the Governor to prevent execution of the judgment, and insisting that Peters had lacked jurisdiction over the matter since he had acted "in manifest opposition to, and violation of the [eleventh] amendment." "300 Given the probability of organized and official defiance, Judge Peters prudently took no steps to enforce his decree.

In 1808, however, Olmstead pressed the issue by asking the United States Supreme Court for a writ of mandamus commanding

299 The early stages of this litigation are unreported but summarized in United States $v$ Peters, 9 US (5 Cranch) 115, 115-35 (1809).

${ }^{300}$ Id at 132 , quoting the resolution of the Pennsylvania legislature. 
Judge Peters to order an attachment and other process to enforce his judgment against the Rittenhouse heirs. A unanimous Court granted the writ. To the contention that the federal courts lacked jurisdiction due to the Eleventh Amendment, Chief Justice Marshall countered that the claim was "not instituted against the state or its treasurer, but against the executrixes of David Rittenhouse, for the proceeds of [the Active].... If these proceeds had been the actual property of Pennsylvania, however wrongfully acquired, the disclosure of that fact would have presented a case on which it is unnecessary to give an opinion. .."301 The "mere suggestion of title" in Pennsylvania was not enough to invoke the jurisdictional limits of the Eleventh Amendment. ${ }^{302}$ Indeed, to Marshall " $[t] h e$ amendment simply provides, that no suit may be commenced or prosecuted against a state." ${ }^{303}$ The Peters decision simply stated what would be underscored in Osborn $v$ Bank of the United States: ${ }^{304}$ the Eleventh Amendment bar applies only to actions making a state the party defendant.

The rationale employed in Peters is not consistent with the view that the Eleventh Amendment was only a narrow limitation upon two heads of Article III's grant of diverse party jurisdiction. Olmstead's suit was in admiralty and thus brought pursuant to an independent head of jurisdiction. The Peters Court could simply have declared that the Eleventh Amendment had no application to suits grounded in a non-diverse party head of jurisdiction. That the Court adopted a more labored route ${ }^{305}$ to reject Pennsylvania's Eleventh Amendment claim suggests that the Court considered the amendment as operating to oust federal courts of all jurisdiction, whatever its Article III source, whenever the party alignment was within the amendment's specifications.

Olmstead's saga did not end with the Peters decision. Pennsylvania's governor, Thomas McKean, an extreme Anti-Federalist, ordered the state militia to deploy around Rittenhouse's home in order to prevent execution of judgment. The United States Marshal gathered his posse and an armed clash was averted only when the Pennsylvanians capitulated upon President Madison's firm an-

${ }^{301}$ Id at 139.

soz Id.

sos Id.

304 22 US (9 Wheat) 738 (1824). See text at notes 339-54 for a discussion of Osborn.

sos While the Court's rationale was consistent with long standing views on the lack of immunity of state officials acting in violation of law, see Engdahl, 44 Colo L Rev at 32-33 (cited in note 177), it was nevertheless the more indirect solution. Marshall was prone to indirection whenever he needed to skirt unpleasantries. 
nouncement that he would use all available federal power to enforce the decree. ${ }^{308}$ Michael Bright, the commander of the state militia, was then prosecuted in federal circuit court before Justice Bushrod Washington. ${ }^{307}$ Bright's defense was entirely legal; he contended that the federal decree he resisted was void because of the Eleventh Amendment and he insisted that a state militiaman following orders was immune from prosecution. ${ }^{303}$ Justice Washington dispensed with this defense on two grounds. First, he elaborated upon the Peters decision by holding that the Eleventh Amendment made no alteration in the common law liability of individual governmental officials. ${ }^{309}$ Next Washington declared that the amendment applied only to suits in law and equity. Because the Olmstead litigation had been brought pursuant to the court's admiralty jurisdiction conferred by Article III and the Judiciary Act of 1789, and since the Eleventh Amendment failed to restrict the exercise of that jurisdiction, the amendment had no role to play. ${ }^{\mathbf{3 1 0}}$

Justice Washington thus did what the entire Court could have done in Peters. Although Washington was acting alone on circuit, his exclusion of admiralty from the Eleventh Amendment bar acquired force because the Supreme Court never explicitly passed on this precise issue during the nineteenth century. Washington's position was finally repudiated by the Court in a post-Hans decision, Ex parte New York (No. 1), ${ }^{\text {111 }}$ but for more than a century his view was considered correct by such esteemed commentators as Joseph Story and Peter DuPonceau. ${ }^{312}$

If Justice Washington's reading of the Eleventh Amendment in the Bright case-that the amendment did not apply to cases in admiralty - was clearly wrong, one might have expected John Marshall to use the Madrazo litigation as a device for correction. Instead, Marshall went out of his way to avoid ruling on the issue. The Madrazo litigation consisted of two decisions, Governor of Georgia v Madrazo ("Madrazo I") ${ }^{313}$ and Ex parte Madrazzo [sic]

${ }^{308}$ Sharp criticism by other states of Pennsylvania's defiance may also have been a factor in Pennsylvania's acquiescence to federal authority. See Warren, 1 Supreme Court at 374-87 (cited in note 264).

soz United States v Bright, $24 \mathrm{~F}$ Cases 1232 (Cir Ct D Pa 1809) (No 14,647).

${ }^{308}$ Id at 1234.

${ }^{300}$ Id at 1236.

$330 \mathrm{Id}$.

311256 US 490 (1921).

312 Joseph Story, 3 Commentaries on the Constitution of the United States 560-61 (Hilliard, Gray, 1833, reprinted De Capo, 1970); Peter DuPonceau, A Brief View of the Constitution of the United States 37-38 (L Acad Philadelphia, 1834).

sis 26 US (1 Pet) 110 (1828). 
("Madrazo II"), ${ }^{314}$ in which Juan Madrazo, a Spanish national, sought to recover a cargo of slaves, or the proceeds of their sale. In 1817 an American privateer captured Madrazo's slave ship and a pirate prize court located off the coast of Florida sold the ship's human cargo. Bowen, an American, bought ninety-five slaves and, in violation of both United States and Georgia law, brought them into Georgia. Bowen's slaves were seized and, in accord with applicable law, delivered to an agent of the Georgia governor for sale. Some were sold and the proceeds deposited in the Georgia treasury. The American Colonization Society then intervened and requested, as it was entitled to do under Georgia law, that the remaining slaves be delivered to it for reconveyance to Africa. Georgia's governor instituted forfeiture proceedings in federal court to accomplish this result.

The suit was opposed by Bowen, who still challenged the validity of Georgia's seizure of the slaves. Madrazo joined the fray by filing a libel in admiralty to recover the unsold slaves and the sale proceeds of those already sold. Both the governor and Bowen opposed this action. While Madrazo explicitly invoked the district court's admiralty jurisdiction, the court failed to take custody of the res, despite the fact that admiralty in rem jurisdiction required it to have control of the disputed property. The court did acquire in personam jurisdiction over the governor, however, and proceeded to render judgment for the governor in the consolidated admiralty and forfeiture actions. On appeal, the circuit court held for Madrazo and dismissed Bowen's and the governor's claims. ${ }^{315}$ Both the governor and Bowen appealed to the Supreme Court where, for the first time, Georgia contended that the lower courts lacked jurisdiction by virtue of the Eleventh Amendment.

Before the appeal was argued, Georgia and Bowen reached a settlement whereby the state turned over the slaves to Bowen, despite the illegality of his claim. The mood in Georgia had turned ugly. Southern suspicion of northern intentions concerning slavery was growing darker and Georgia was openly defiant of the attempts of the John Quincy Adams administration to preserve Indian lands in Georgia from state exploitation. Thus, when the Marshall Court decided Madrazo $I$ it was a virtual certainty that any decision in favor of Madrazo would also be openly defied. Marshall, ever the master of judicial realpolitik, concocted a decision that affirmed the circuit court's dismissal of both Bowen's and the 
governor's claim, but reversed the award to Madrazo on the ground that "[ $t]$ he decree cannot be sustained as against the state, because, if the 11th amendment to the Constitution does not extend to proceedings in admiralty, it was a case for the original jurisdiction of the Supreme Court" because it was a suit between a state and a citizen of a foreign state. ${ }^{316}$ The suit was against the state because the governor was sued "not by his name, but by his title" and because "no case is made which justifies a decree against him personally."317

Perhaps enlightened by Marshall's jurisdictional views, Madrazo filed an original admiralty libel against Georgia in the Supreme Court. But now the Court was quick to point out that it lacked original jurisdiction in admiralty because the disputed property was not in possession of a court in admiralty. ${ }^{318}$ Thus, it did not matter whether the Eleventh Amendment applied to admiralty proceedings. The Supreme Court's only jurisdictional basis was party alignment: Madrazo, a Spanish national, sought to sue Georgia. Of course, it was precisely this party-based jurisdiction that the Eleventh Amendment denied the federal courts. Unsurprisingly, Marshall dismissed Madrazo's claim as "a mere personal suit against a state, to recover proceeds in its possession, and in such a case, no private person has a right to commence an original suit in this court against a state." 319

As in Peters, Marshall's statement is broad enough to encompass the possibility that he thought the Eleventh Amendment barred actions against states rooted in federal question jurisdiction. If that were the case it would seem likely that in the Madrazo cases Marshall would have concluded that the Eleventh Amendment barred actions against states arising under the then-principal head of federal question jurisdiction-admiralty. Such a result would have accomplished Marshall's probable desire to avoid immersing the Court in the fiery crucible of Georgian defiance of federal authority, but would have come at the price of a substantial diminution of federal judicial authority. Instead, Marshall skirted the issue by crafting a disposition that avoided both confrontation

${ }^{316}$ Madrazo I, 26 US (1 Pet) at 124. Even if Madrazo $I$ was a suit between a foreign national and a state, Marshall's reasoning seems flawed since $\S 13$ of the 1789 Judiciary Act gave the Supreme Court original but not exclusive jurisdiction over these actions. 1 Stat at 80. Moreover, Article III does not confer original admiralty jurisdiction on the Supreme Court.

317 Madrazo I, 26 US (I Pet) at 123, 124.

s18 Madrazo II, 32 US (7 Pet) at 632 (1833).

320 Id at 632 . 
with Georgia and erosion of Marshall's nationalist ideals. Thus, while Marshall may have thought, as the Court suggested in $\mathrm{Pe}$ ters, that the Eleventh Amendment was thought to be a partybased jurisdictional ouster, he avoided ruling on the issue by adhering doggedly to the amendment's text. At bottom, Madrazo lost the second time around because the Court's only jurisdictional basis was not in admiralty (which would have required Marshall to face the unpleasant task he avoided) but in state-alien diversity. With that as the jurisdictional foundation for Madrazo's claim, the Eleventh Amendment provided Marshall a simple textual answer.

In any case, what is clear from these cases is that in neither case was there any suggestion that the Eleventh Amendment might afford a general immunity from suit; rather, the focus in both was upon identifying the categories of suits against states that were barred from federal court by virtue of the Eleventh Amendment.

\section{Section 25 cases: Cohens and Worcester.}

Pursuant to Article III's grant to the federal courts of power to decide cases "arising under this Constitution, the Laws of the United States, and Treaties," vested in the Supreme Court appellate jurisdiction over certain federal question claims litigated in state courts. Since the federal courts did not receive original federal question jurisdiction until 1875 , this section served as the principal avenue for presentation of a claim that a state had acted in violation of a federal statute or a Constitutional prohibition. It thus carried the potential to pose the broad question of whether the Eleventh Amendment created a general immunity from suit, including appeals of judgments rendered in cases where the state had been the plaintiff, regardless of the citizenship of the parties.

Precisely these issues came before the Court in Cohens $v$ Virginia. ${ }^{321}$ The Cohen brothers had been convicted in a Virginia court of the crime of selling lottery tickets. They appealed to the Supreme Court on the basis of an act of Congress that authorized the District of Columbia to organize a lottery. The Marshall Court affirmed the convictions on the ground that the act did not authorize the sale of lottery tickets outside the District, but in reaching this decision Marshall was able to sustain the Court's appellate ju- 
risdiction over a number of difficult constitutional objections. One of these was the Eleventh Amendment. Virginia's counsel argued that, because the state was a party, the federal courts were deprived of appellate jurisdiction. ${ }^{322}$ The principle Virginia urged on the Court was that "a sovereign independent State is not suable, except by its own consent." 323 The Cohens' counsel responded by asserting that it was Virginia that had sued the Cohens; it would be a monstrous perversion of sovereign immunity to prevent an accused from appealing a conviction. ${ }^{324}$

Rather than adopting the simple solution offered by the Cohens' counsel, Marshall reached out for a more complicated and vastly broader answer. He began by asserting that the federal judicial power conferred by Article III "extends to all cases arising under the constitution or a law of the United States, whoever may be the parties." 325 Since Article III included all federal question cases, the presence of a state as a party did not defeat jurisdiction. Indeed, the Court must review "cases where a State shall prosecute an individual who claims the protection of an act of Congress ... [for] the preservation of the constitution and laws of the United States." 326 The Eleventh Amendment did not alter this jurisdictional grant for two reasons. The simple reason was that the Cohens were citizens of Virginia, not of another state. ${ }^{327}$ The broader reason was that the Cohens had originally been defendants, not plaintiffs, and that, therefore, this was not "a suit commenced or prosecuted against" a state..$^{328}$

The Cohens decision presents a curious brew. By aggressively asserting that there were no party-based limitations on federal question jurisdiction and by framing the issue as one of sovereign immunity, Marshall seemed poised to deliver dictum that a state could be a party defendant in any federal question case ${ }^{329}$ But by offering the Cohens' Virginia citizenship as a reason for the inapplicability of the Eleventh Amendment, Marshall retreated from

322 Id at 302-09 (argument of Mr. Barbour), and at 315 (argument of Mr. Smyth).

323 Id at 380 (Marshall restating the argument of counsel).

324 Id at 350 (argument of Mr. Ogden), and at 366-67 (argument of Mr. Pinkney).

${ }^{325}$ Id at 392 (emphasis added).

326 Id at 387,391 .

327 Id at 412 .

328 Id at $406-12$.

s20 While Marshall conceded that a citizen might not be able to sue his own state to recover an unconstitutional export tax, he reasoned that such a case arose under the common law of assumpsit rather than under the Constitution. Id at 402-03. Marshall did not opine about the status of such a suit seeking a prospective injunction against collection of such a tax. 
his earlier assertion and did not close out the possibility that at least some federal question suits might be denied the federal courts by the amendment. Clearly repudiated, however, was the notion that the Eleventh Amendment afforded states a blanket immunity from federal court jurisdiction. That principle had been argued to the Court and rejected.

Some of the ambivalence of Cohens was removed eleven years later with the Court's decision in Worcester $v$ Georgia. ${ }^{330}$ For years Georgia had sought to oust the Cherokee and Creek Indians from their lands, and to remove the federal officials who administered the lands. ${ }^{331}$ Georgia's efforts were a plain violation of federal $\mathrm{law}^{\mathbf{3 3 2}}$ but generally went unpunished. As part of its effort, Georgia required whites residing on Indian lands to obtain a license from the state. Worcester, a Vermont missionary and federal postmaster, was indicted and convicted in a Georgia court for failure to obtain the required state license. ${ }^{333}$ Worcester invoked $\S 25$ to appeal his conviction to the Supreme Court. Although served with process requiring it to respond to the Court's writ of error, Georgia refused to appear. ${ }^{334}$ Given Georgia's contumacious history and the especially nasty position it took with respect to Indian lands, it was entirely predictable that Georgia would ignore a Supreme Court decision adverse to it. ${ }^{335}$ The politically easy solution would have been to expand upon the reasoning of Cohens by holding that the Eleventh Amendment barred Worcester's appeal because he was a citizen of Vermont, not Georgia. Without discussion of the Eleventh Amendment, the Court took jurisdiction and reversed the conviction.

The Supreme Court's decisions in Worcester and Cohens

sso 31 US (6 Pet) 515 (1832).

ssi The entire sordid history may be perused in William G. McLoughlin, Cherokee Renascence in the New Republic (Princeton, 1986). See also Warren, 2 Supreme Court at 189. 239 (cited in note 264); Albert J. Beveridge, 4 Life of John Marshall 539-51 (Houghton Mifflin, 1919).

${ }^{332}$ See Gibbons, 83 Colum L Rev at 1953-54 \& n 346 (cited in note 2), for the statutory history of this collision between Georgia and the United States.

${ }^{333}$ Worcester, 31 US (6 Pet) at 537 (1832).

${ }^{334}$ Id at 533-34 (order demanding that the state appear before the Court). See also Beveridge, 4 The Life of John Marshall 548-49 (cited in note 331); Warren, 2 The Supreme Court in United States History 214 (cited in note 264) (noting the absence of an appearance on the part of Georgia).

395 Popular tradition has it that President Jackson greeted Marshall's reversal of Worcester's conviction with the quip, "John Marshall has made his decision, now let him enforce it." While Charles Warren doubted that Jackson ever uttered the phrase there is no denying that Georgia's belligerence was real. See Warren, 2 Supreme Court at 219 (cited in note 264). 
made clear that the Court's federal question appellate jurisdiction was undisturbed by the Eleventh Amendment. Despite Hans and its progeny, this rule continues to exist. Yet, if the Eleventh Amendment was truly a complete grant of sovereign immunity, Worcester's appeal would have been dismissed or, at the very least, this rule would have died in the doctrinal furnace that has been stoked since Hans. Of course, even after Hans, one easy explanation for the rule's continued vitality could be Marshall's second reason for upholding the Cohens' appeal: an appeal against a state is not a suit "commenced or prosecuted" against a state. But if the post-Hans conventional interpretation of the amendment ignores the last fourteen words of the amendment in creating a broad immunity for the states, why should it be limited by any other words in the text? That the rule of Cohens and Worcester has endured is yet another indication that the broad immunity from suit in federal court enjoyed by the states after Hans has its conceptual roots somewhere other than in the soil of the Eleventh Amendment.

\section{Suits between states.}

If, as the conventionalists contend, the Eleventh Amendment had been intended to preserve inviolate state immunity from any suit without its consent, the Court should have concluded that its original jurisdiction over suits between the states had been eviscerated with the amendment's ratification. ${ }^{336}$ That, of course, did not happen. In Rhode Island $v$ Massachusetts the Taney Court expressly rejected Massachusetts's argument that the Eleventh Amendment deprived the Court of any jurisdiction over suits between states. ${ }^{337}$ The case appears to be the only instance in which a state took this position with respect to the Court's original jurisdiction over litigation between states. Indeed, in an earlier boundary dispute between New York and New Jersey, the New York at-

sse The reasoning in Hans assumes that the Eleventh Amendment modifies Article III by conferring a complete immunity from suit upon the states. Logically, this immunity should extend to include suits between states or brought by the United States, but the Supreme Court has never extended Hans this far. See United States $v$ Mississippi, 380 US 128 (1965); Rhode Island v Massachusetts, 37 US (12 Pet) 657 (1838); North Dakota v Minnesota, 263 US 365 (1923).

${ }^{337} 37$ US (12 Pet) 657, 731 (1838). The Court's rationale was evidently rooted in the Eleventh Amendment's text: "while [the Eleventh Amendment] . . . took from this Court all jurisdiction, past, present, and future ... of all controversies between states and individuals; it left its exercise over those between states as free as it had been before." Though Justice Baldwin's description of the effect of the Eleventh Amendment is overbroad, it does support the jurisdictional ouster view. 
torney general argued that the Court lacked jurisdiction on the ground that the Court's original jurisdiction over interstate litigation was not effective without congressional legislation to implement the grant. ${ }^{338}$ While this point followed Justice Iredell's inferential suggestion in Chisholm that congressional action was needed to subject a state to any suit in the federal courts, New York did not explicitly urge the Eleventh Amendment as a jurisdictional bar. If the amendment was thought to guarantee such expansive immunity, it is most surprising that New York's attorney general, already preoccupied with objections to the Court's jurisdiction, failed to assert explicitly such a killing defense to New Jersey's suit. Once more, the Eleventh Amendment was viewed, in the days before Hans was decided, as only a jurisdictional trump of Article III. Although this trump cut across all Article III grants of jurisdiction, it was limited to its text. Thus, the amendment did not apply to suits brought by states simply because they were not "Citizens of another State."

\section{The Bank Cases: When the state is not the state.}

When Congress chartered the Second Bank of the United States, it made it "able and capable . . . to sue and be sued ... in any circuit court of the United States." 339 In reliance upon that provision the Bank sued in federal circuit court Ralph Osborn, Ohio's auditor, and other Ohio officials. The Bank sought recovery of a crushing $\$ 100,000$ tax which Ohio had assessed upon the Bank and collected by force ${ }^{340}$ in defiance of the Supreme Court's ruling in McCulloch $v$ Maryland. ${ }^{341}$ The Court heard and decided the matter in conjunction with the less famous case of Bank of the United States $v$ Planters' Bank of Georgia, ${ }^{342}$ in which the Bank invoked the same charter provision to sue in federal circuit court the Planters' Bank for payment in specie of its notes, which the

${ }^{338}$ New Jersey v New York, 28 US (3 Pet) 461, 464 n (a) (1830).

${ }^{339}$ Bank of the United States Act, ch $44, \S 7,3$ Stat 266, 269 (1816). A similar provision in the act creating the first Bank of the United States, though without specific mention of the federal courts, had been construed as conferring only capacity, not federal jurisdiction. Bank of the United States v Deveaux, 9 US (5 Cranch) 61, 85-86 (1809). As a result, the first Bank was forced to litigate in the first instance in state courts; federal appellate review was available only by virtue of $\S 25$ of the 1789 Judiciary Act. Some commentators believe this jurisdictional rule played an important role in preventing the first Bank from functioning as a true central bank. See Gibbons, 83 Colum L Rev at $1956 \mathrm{n} 358$ (cited in note 2).

${ }^{340}$ Osborn $v$ Bank of the United States, 22 US (9 Wheat) 738, 739 (1824).

34117 US (4 Wheat) 316 (1819).

34222 US (9 Wheat) 904 (1824). 
Bank of the United States had acquired by assignment. In Osborn $v$ Bank of the United States, the Bank instituted suit in Ohio's federal circuit court, citing the Bank charter provision as the basis for federal jurisdiction. The circuit court awarded judgment to the Bank and the Supreme Court affirmed.

In deciding these cases the Court was required to consider and reject several objections to original federal court jurisdiction, including one based on the Eleventh Amendment. Writing for the Court, John Marshall first interpreted the Bank's congressional charter as vesting original jurisdiction in the circuit courts. Next Marshall concluded that this statutory grant of jurisdiction was within the constitutional limits of Article III. He did so by maintaining that the federal courts' original jurisdiction was as large as its appellate jurisdiction, ${ }^{343}$ and that since the Bank's capacity to contract was a matter of federal law, there was a sufficient "original ingredient in every cause" to support federal jurisdiction under Article III. ${ }^{344}$ Jurisdiction was thus in no way premised upon diverse parties but rested squarely upon the existence of a federal question. $^{345}$

Osborn raised the Eleventh Amendment issue by contending that the Bank's attempt to obtain restitution from him, a state officer performing his official duties, was "substantially, though not in form," a suit against the state. ${ }^{346}$ Marshall rejected the contention by arguing that such a conclusion would hamper the enforcement of federal law, would be inconsistent with Article III's provision for federal jurisdiction of suits "affecting" ambassadors but not those similarly "affecting" states, and would be at odds with the analogous rule that an executor's citizenship rather than that of the beneficiaries was dispositive for diversity purposes. ${ }^{347}$ Accordingly, Marshall concluded that the Eleventh Amendment was "limited to those suits in which a state is a party on the record."

34 Osborn, 22 US (9 Wheat) at 821.

344 Id at 824. Marshall's position is extreme by modern standards, for his conception of the requisite federal connection seems to permit federal jurisdiction founded on something as remote as the acquisition of title by virtue of congressional action. See Shulthis v McDougal, 225 US 561, 570 (1912) (rejecting such an expansive reading of federal question jurisdiction).

${ }^{315}$ In argument before the Court, all counsel agreed that the case was one "arising under ... [the] Constitution [and] Laws of the United States." US Const, Art. III, $₹ 2$, cl 1. See Osborn, 22 US (9 Wheat) at 757 (argument of Mr. Hammond), 798 (argument of Mr. Clay), 806 (argument of Mr. Wright). The Court agreed. Id at 818-28.

${ }^{346}$ Osborn, 22 US ( 9 Wheat) at 846.

s47 Id at 847-58.

348 Id at 857. 
Had Marshall and the Court believed that the Eleventh Amendment merely constricted the federal courts' state-citizen diversity jurisdiction, as the revisionists now contend, it would not have been necessary to create the party-of-record rule. For under the revisionists' view, the Bank's claim, even if against the State of Ohio, would have been exempt from the Eleventh Amendment since it was founded upon a federal question. Precisely this construction was urged upon the Court by Henry Clay, the Bank's counsel. ${ }^{349}$ That Marshall eschewed Clay's straightforward ratio decidendi is a strong hint that he viewed the amendment as ousting the federal courts of jurisdiction under any head of Article III whenever out-of- staters sued a state. But Marshall left even firmer clues that this was his view. He expressly conceded that it "was not in the power of the Bank" to make Ohio a party defendant since " $[t]$ he eleventh amendment . . . has exempted a state from the suits of citizens of other states, or aliens. . . ."350 Since Marshall had already determined that the Bank's suit was premised on the federal question jurisdiction created by the Bank's charter, he must have thought that the Eleventh Amendment operated as a party-based ouster of federal jurisdiction even in federal question cases.

It is true that after describing the amendment as a "limitation of a power supposed to be granted in the original instrument; and to understand accurately the extent of the limitation, it seems proper to define the power that is limited," Marshall began his definitional effort by quoting the state-citizen and state-alien diversity clauses of Article III. ${ }^{351}$ Later, in summing up the Eleventh Amendment issue, Marshall observed that the "amendment, which restrains the jurisdiction granted by the constitution over suits against states ... has its full effect, if the constitution be construed as it would have been construed, had the jurisdiction of the court never been extended to suits brought against a state, by the citizens of another state, or by aliens." ${ }^{362}$ These statements seem to

${ }^{349}$ Clay contended that "even if the state be a party, that circumstance would not oust the jurisdiction of the court, in a case arising under the constitution and laws of the Union. There, the nature of the controversy, and not the character of the parties, must determine the question of jurisdiction. Such is conceived to be the spirit and effect of the decision of the court, in the case of Cohens $v$ Virginia." Id at 798.

${ }^{350}$ Id at 847. Marshall drove home the point two pages later: "That the Courts of the Union cannot entertain a suit brought against a state by an alien, or a citizen of another state, is not to be controverted." Id at 849 .

${ }^{351}$ Id at 850 .

${ }^{352}$ Id at $857-58$. 
suggest Marshall thought that the Eleventh Amendment revived an original implicit limitation in Article III upon federal jurisdiction, and that this limitation applied only to suits originating under the state-citizen and state-alien diversity clauses. ${ }^{353}$ But if this was Marshall's understanding, his rejection of Clay's identical argument seems inexplicable and his painstaking construction of the party-of-record rule would have been entirely unnecessary to reach the Osborn result. Moreover, such an interpretation squarely conflicts with Marshall's earlier more direct statement that the amendment prohibited the joinder of Ohio as a defendant in this federal question case.

While the party-of-record formulation neatly avoided any direct examination of the Eleventh Amendment's applicability to federal question cases, it proved to be too much even for Marshall. In Madrazo $I^{354}$ he effectively sabotaged his rationale in Osborn by dismissing a suit brought against the governor of Georgia in his official capacity because in reality the suit was against the state. Marshall's attempt to distinguish the cases is most unpersuasive. However, by creating the inference that the presence of a state as a party defendant in a federal question case would be enough to invoke the Eleventh Amendment, Marshall's reasoning in Osborn was consistent with his suggestions in Peters. When all three cases are considered, it is clear that Marshall avoided construing the amendment as having no impact upon federal question jurisdiction, even when such a construction was invited by the cases. The Marshall Court must have believed, or at least feared, that the amendment did just the opposite.

The companion to Osborn, Planters' Bank, raises even more problems. In Planters' Bank the defendant was a bank partially owned by the state of Georgia. Again jurisdiction was premised on a federal question (the Bank's charter); again the defendant raised the Eleventh Amendment as a defense; and again the Marshall Court held that the defendant was not the state. Yet, in holding that the suit was not against Georgia, Marshall provided more conclusions than rationales. The suit was "against a corporation," not the state and, in any case, "when a government becomes a partner in any trading company, it divests itself, so far as concerns the transactions of that company, of its sovereign character. . . . Geor-

${ }^{383}$ This is the revisionist interpretation of Marshall's remarks. See Fletcher, 35 Stan L Rev at 1086 (cited in note 2).

3s4 Governor of Georgia v Madrazo, 26 US (1 Pet) 110 (1828). See notes and text at notes 313-17. 
gia, by giving the [Planters'] bank the capacity to sue and be sued, voluntarily strips itself of its sovereign character, . . . and waives all privileges of that character. ..."355

Marshall's assertion that Georgia was not a party was difficult to reconcile with Bank of the United States $v$ Deveaux, ${ }^{356}$ in which a diversity suit by a corporation had been considered a suit by its shareholders. ${ }^{367}$ Further, there is nothing in the Eleventh Amendment itself that seems to exempt from its scope suits against states acting in a "proprietary" as opposed to a "governmental" character. ${ }^{358}$ As the dissenting Justice Johnson put it, every suit against a state was in its sovereign capacity for "in what other capacity can a

${ }^{35 s}$ Planters' Bank, 22 US (9 Wheat) at 906-08 (1824).

ss6 9 US (5 Cranch) 61 (1809).

${ }^{357}$ An attempt can be made to reconcile the two cases on the grounds that they serve different policies. Deveaux viewed a corporation as a fictional aggregation of individuals in order to uphold federal jurisdiction because it was feared that state courts might not "administer justice as impartially as those of the nation" to out-of-staters. Deveaux, 9 US (5 Cranch) at 87. That jurisdictional concern was not present in Planters' Bank due to the federal jurisdiction conferred by the Bank's charter. See note 339. Instead, Marshall recognized that corporations can and do act apart from their owner-shareholders. But, in Deveaux, Marshall observed that outsiders "are not less susceptible of these apprehensions [of state court favoritism] ... because they are allowed to sue by a corporate name." Deveaux, 9 US ( 5 Cranch) at 87 . This statement suggests that the real basis for Deveaux is the view that shareholders are the real parties in interest to corporate claims and defenses. If so, it is hard to see why the separate legal personality of the corporation ought to be recognized in Planters' Bank but not Deveaux.

${ }^{368}$ The distinction is well recognized in modern American law concerning the immunity from suit of a foreign sovereign. American courts apply the doctrine of restrictive immunity, which immunizes a foreign sovereign for its "public" but not "private" acts. Restrictive immunity was adopted by the State Department in 1952. See Letter from Jack B. Tate, Acting Legal Advisor to the Dept. of State, to Philip P. Perlman, Acting Attorney General (May 19, 1952), reprinted in 26 Dept State Bull 984 (1952). A slightly modified version of the rule was eventually enacted into law by the Foreign Sovereign Immunities Act of 1976, Pub L No 94583,90 Stat 2892 , codified at 28 USC $\S 1603$ (1982). For a discussion of restrictive immunity prior to the act, see Robert B. von Mehren, The Foreign Sovereign Immunities Act of 1976, 17 Colum J Transnatl L 33, 39-43 (1978); Annotation, Modern Status of the Rules as to Immunity of Foreign Sovereign From Suit in Federal or State Courts, 25 ALR3d 322, 33239 (1969). For a discussion of the effect of the act upon restrictive immunity, see von Mehren, 17 Colum J Transnatl $L$ at 48-54. For a discussion of problems with practice under the act see Mary Kay Kane, Suing Foreign Sovereigns: A Procedural Compass, 34 Stan L Rev 385 (1982). In Marshall's time, foreign sovereign immunity was thought to be absolute. See The Schooner Exchange v McFaddon, 11 US (7 Cranch) 116 (1812). Thus, Marshall proposed differing immunity rules for states (Planters' Bank: restrictive immunity) and foreign nations (The Schooner Exchange: absolute immunity). Nowhere does he explain the source of these differences, although Marshall does recognize in The Schooner Exchange "a clear distinction ... . between the rights accorded to private individuals or private trading vessels, and those accorded to public armed ships which constitute a part of the military force of the nation." Id at 143. That distinction, however, is inadequate to encompass the restrictive immunity doctrine proposed for states in Planters' Bank. 
state appear, or even exist?"358 Finally, by raising the issue of waiver, Marshall enormously clouded his analysis of the Eleventh Amendment. If the Eleventh Amendment operates as a limitation upon the federal courts' subject matter jurisdiction, its boundaries cannot be waived. ${ }^{360}$ The waiver suggestion, therefore, raises the implication that the immunity principles to which Marshall was responding were located elsewhere.

While the Bank cases carry with them, perhaps more than any other pre-Civil War cases, the seeds of a Tenth Amendment doctrine of state sovereign immunity disguised within the Eleventh Amendment, that principle did not blossom until the Reconstruction. Generally, the pre-Civil War cases treat the Eleventh Amendment as a party-based jurisdictional ouster. Perhaps for that reason the Marshall Court nibbled away at its edges, rather than confronting the amendment, as part of that Court's long running exercise in expanding the affirmative jurisdictional grant of Article III.

\section{The Evolution of the Eleventh Amendment: Reconstruction and Historical Revision}

It was not until the Reconstruction that current notions of sovereign immunity began to emerge. The economic dislocations occasioned by the Civil War and its aftermath caused many southern states to repudiate their bond obligations. ${ }^{361}$ This wholesale rejection of the Constitution's Contract Clause ${ }^{\mathbf{3 6 2}}$ was deadly serious. It was also no empty threat. In the wake of the Compromise of $1877^{363}$ and its legislative progeny, the Posse Comitatus Act, ${ }^{\mathbf{3 6 4}}$ the federal government lacked both the will and the power to enforce any judicial decisions ordering states to pay their bond obligations. Thus, the Court was faced with the unpalatable choice of abandoning accepted Contract Clause doctrine or establishing the potentially crippling precedent of state non-compliance with Supreme Court judgments. The Court's solution to this dilemma was

339 Planters' Bank, 22 US (9 Wheat) at 912 (Johnson dissenting).

${ }^{360}$ See notes $14-16$ and accompanying text.

s61 See generally Orth, The Judicial Power at 47-109 (cited in note 2).

so2 US Const, Art I, § 10, cl 1.

${ }^{363}$ See generally Paul L. Haworth, The Hayes-Tilden Disputed Presidential Election of 1876 (Burrow Bros, 1906); Orth, The Judicial Power at 53-57 (cited in note 2); Comer Vann Woodward, Reunion and Reaction: The Compromise of 1877 and the End of Reconstruction (Little, Brown, 1951).

sot Act of June 18, 1878, ch $263, \S 15,20$ Stat 145, 152. This Act severely circumscribed the lawful use of the army to enforce the laws. 
to read the Eleventh Amendment as establishing, as a constitutional principle, state sovereign immunity from suit in federal court, whatever the asserted jurisdictional basis for the suit.

The history begins before the Compromise of 1877, with the case of Board of Liquidation $v \mathrm{McComb}^{365}$ a rare victory for a bondholder. Already, the southern states were employing a dazzling array of devices to dilute their obligations and, predictably, these moves were being challenged by aggrieved bondholders. Louisiana had enacted a statute offering its creditors the opportunity to exchange their old Louisiana bonds for new ones, called "consolidated bonds," bearing a higher interest rate. The catch for bondholders was that for each $\$ 100$ of old bonds they would receive $\$ 60$ in new "consolidated" bonds. McComb accepted the offer, and then became incensed when Louisiana raised the exchange rate from 60 percent to par value only for the benefit of the politically powerful Louisiana Levee Company. McComb brought a diversity action seeking to enjoin the Louisiana officials who composed the state's Board of Liquidation from exchanging the Levee Company's bonds at par. For a unanimous Supreme Court, Justice Bradley concluded that a private person may obtain injunctive relief against state officers violating their constitutional duties. ${ }^{366}$ The Eleventh Amendment was no barrier to the action because, in the tradition of Osborn, the state was not a party on the record.

Shortly after the $M c C o m b$ decision the 1876 presidential election produced the so-called Compromise of 1877, in which the Republicans were given the presidency in exchange for an end to federal intervention in Southern affairs. ${ }^{367}$ Louisiana promptly took advantage of this new freedom to adopt a new constitution, replacing the Reconstruction constitution authored by carpetbag Republicans. In the new 1879 constitution Louisiana included a provision that ended the taxation necessary to pay interest on the consolidated bonds, cut the interest rate on those bonds from 7 percent to 2 percent, and offered consolidated bondholders the opportunity to exchange their consolidated bonds for yet another new issue, bearing interest at 4 percent but available at an exchange rate of 75 cents per dollar of consolidated bonds tendered.

Angered non-Louisianan consolidated bondholders promptly brought suit in federal court, claiming these provisions violated the Contracts Clause, and seeking an order compelling Allen Jumel,

${ }^{365} 92$ US 531 (1875).

${ }^{368}$ Id at 541.

s67 See note 363 . 
the state treasurer, to pay interest on the consolidated bonds in accordance with the prior terms. In 1883 the case, Louisiana $v$ Jumel, ${ }^{368}$ reached the Supreme Court. By a seven to two margin the Court concluded that the claim was really against the state and thus foreclosed by the Eleventh Amendment. McComb was implausibly distinguished and the Court admitted that it was forced to its conclusion by the difficulty of enforcing a judgment for the bondholders:

The remedy sought ... would require the court to assume all the executive authority of the State ... and to supervise the conduct of all persons charged with any official duty in respect of the levy, collection, and disbursement of the tax in question until the bonds ... were paid in full. ... It needs no argument to show that the political power cannot be thus ousted of its jurisdiction and the judiciary set in its place. ${ }^{368}$

In the same term as Jumel the Court was faced with another challenge to the Louisiana debt readjustment caper. Following the advice of sophisticated legal counsel, the states of New Hampshire and New York enacted legislation authorizing their attorneys general to accept assignments of Louisiana bonds, prosecute the assigned claims, and remit the net proceeds collected to the assignors. The strategy was a frank gambit to avoid the Eleventh Amendment, for its jurisdictional denial did not in terms extend to suits between the states. Yet, in New Hampshire $v$ Louisiana ${ }^{370}$ the Court found that the Eleventh Amendment barred cases where the state was acting as a collection agency for citizens seeking to assert claims against another state. ${ }^{371}$

In reaching this decision, the Court in effect endorsed Chisholm's view that state sovereignty was superseded to the extent of the jurisdictional grants of Article III. Chief Justice Waite noted that New Hampshire was seeking to assert a sovereign's right to collect from other sovereigns debts owed to its citizens. That right "is well recognized as an incident of national sovereignty" but American states lacked it because they had surrendered such sovereign powers with the constitutional union. .72 $^{2}$ Waite found some proof for this proposition in Chisholm; if Article

\footnotetext{
s68 107 US 711 (1883).

ses Id at 727-28.

${ }^{370} 108$ US 76 (1883).

s71 Id at 89.

${ }^{372}$ Id at 90 .
} 
III originally permitted private claims against states by citizens of another state there was no reason to suppose that states had retained the duplicative remedy of suing on behalf of their citizens. ${ }^{373}$ Of course, with the Eleventh Amendment the citizen went remediless, for she no longer could sue another state directly and her own state had surrendered the sovereign prerogative of suit on her behalf. Put another way, if Waite had thought that Chisholm was wrong, he should have concluded that Article III did not diminish the sovereign capacities of the states, and thus, that New Hampshire could continue to possess the right to press claims against other states on behalf of its citizens. In fact, he concluded exactly the opposite and thereby validated the reasoning of Chisholm.

As was the case with Chisholm, the New Hampshire Court failed to address the possibility that the Tenth Amendment's reservation of sovereignty to the states might place limits on cessions of state sovereignty that could be inferred in Article III. Unlike Chisholm, which involved an explicit jurisdictional grant, New Hampshire involved an implicit Article III limitation on state sovereignty. The Tenth Amendment is surely most relevant to such implicit constitutional invasions of state sovereignty. The New Hampshire Court's failure to address this issue indicates either that it thought the Tenth Amendment hortatory or, more likely, that it wished to skirt the issue in order to avoid the fundamental problem, admitted in Jumel, that there was no practical way to enforce an adverse judgment against Louisiana.

The rationale of the Court's decision in New Hampshire makes the holding in Hans $v$ Louisiana ${ }^{374}$ all the more curious. Hans was a suit by a Louisiana citizen who was attempting to enforce against the state the terms of its repudiated consolidated bond obligations. The action was dismissed in the trial court on Eleventh Amendment grounds even though the party alignment was not within the text of the amendment. ${ }^{375}$ The trial judge had concluded that "a state can no more be sued contrary to its continuing assent than can the dead"376 but never made clear the connection between this assertedly "settled idea[]"s73 and the Eleventh Amendment. The connection was in no way textual, but rooted in

373 Id at 91.

374134 US 1 (1890).

${ }^{376}$ Hans v Louisiana, 24 F 55 (Cir Ct E D La 1885), aff'd, 134 US 1 (1890).

${ }^{376}$ Id at 66.

377 Id. 
"the inability of a court to deal directly with the treasury of a state." "378 Stripped of euphemism, Louisiana possessed sovereign immunity because the federal judiciary was unable, and the President and Congress unwilling, to enforce decrees adverse to Louisiana.

When the Supreme Court decided Hans it eschewed any such policy rationales but wholeheartedly endorsed the broad grant of sovereign immunity created by the trial judge. To do this, Justice Bradley first had to repudiate in principle, if not explicitly, the New Hampshire conclusion that Chisholm was a fundamentally correct exposition of the interplay between state sovereignty and Article III. Justice Bradley simply declared it wrong: "[i]n view of the manner in which ... [Chisholm] was received by the country, the adoption of the Eleventh Amendment, the light of history and the reason of the thing, we think we are at liberty to prefer Justice Iredell's [dissent]. . . ."379 In fact, Bradley preferred his own filtered view of Iredell's dissent, for he treated it as a constitutional opinion rather than as an interpretation of the 1789 Judiciary Act. While it is true that Iredell finished his Chisholm opinion with the bald dictum that congressional action to subject the states to suit in the federal courts would likely be unconstitutional, he never provided any clue to the rationale for his conclusion. Undeterred by Iredell's omission, Justice Bradley found a rationale in Justice Gray's intemperate dissent in United States $v$ Lee, ${ }^{380}$ in which Bradley had joined eight years earlier.

United States $v$ Lee involved the efforts of George W.P.C. Lee, Robert E. Lee's son, to recover Arlington, the family home, from the United States government. In 1862, Congress had passed a direct tax to finance the Civil War. Of the Virginia portion, $\$ 92.07$ was assessed against the Lee estate. Lee's mother, who held title at that time, sought to pay the tax through intermediaries but her tender was refused because it was not made in person. Accordingly, Arlington was seized and sold to the federal government for non-payment of the tax. After the war, and while Arlington was in the process of being converted into a cemetery, George Lee brought an ejectment action in the Virginia courts against Kaufman and Strong, the federal agents in charge of the property, and numerous other federal officers occupying the land. The case was removed to federal court and the United States intervened in de-

${ }^{378}$ Id at 68.

378 Hans, 134 US at 18-19.

s80 106 US 196, 223 (1882). 
fense of its seizure. Following a jury trial, verdict was rendered in Lee's favor, and sustained on appeal to the Supreme Court. To the contention that the United States was immune from suit, the majority offered the long settled view that suits against governmental officers to obtain assets unlawfully held by them were not against the sovereign..$^{381}$

The surprise in the case was Justice Gray's dissent, in which Chief Justice Waite and Justices Bradley and Woods joined. Gray initially contended that the United States possessed immunity because "it is essential to the common defence and general welfare that the sovereign should not, without its consent, be dispossessed by judicial process of . . . military posts . . . necessary to guard the national existence." ${ }^{\text {382 }}$ From there he quickly began to blend together authorities dealing with the common law notion of sovereign immunity of nations ${ }^{383}$ and cases construing the Eleventh Amendment. ${ }^{384}$ Gray introduced the Eleventh Amendment cases in order to demonstrate that "[i]n those cases in which judgments have ... been rendered by this court against individuals concerning money or property in which a State had an interest, either the money was in the personal possession of the defendants and not in the possession of the State, or the suit was to restrain the defendants by injunction from doing acts in violation of the Constitution. . . ."385 The point of this exercise was that, in Gray's view, the Lee case fell outside this description. Not only was Gray's characterization of dubious accuracy, ${ }^{388}$ it unnecessarily invested the Eleventh Amendment with an aura of sovereign immunity. Gray hardly did better with the claimed immunity from suit asserted by the United States; he simply endorsed such immunity as a fundamental "axiom[] of public law," ${ }^{387}$ notwithstanding the limited federal sovereign immunity that the Marshall and Taney Courts had created as a matter of federal common law. ${ }^{388}$ In short, Gray's opinion was

\footnotetext{
38: Id at 209-18.

382 Id at 226.

s83 Id at 226-42.

384 Id at 242-47.

385 Id at 242 .
}

${ }^{388}$ The decision in Osborn $v$ Bank of the United States, 22 US (9 Wheat) 738 (1824) defies Gray's characterization, for in that case the tax that the Bank sought to recover was most definitely in Ohio's possession. Although the $\$ 100,000$ at issue had been kept "separate from the other funds of the treasury," id at 833 (emphasis added), it was nevertheless sitting in a chest in Ohio's state treasury and had already been entered as a deposit on the books of the treasury. Id at 833, 868-69.

${ }^{387}$ Lee, 106 US at 226.

${ }^{388}$ See, for example, The Davis, 77 US (10 Wall) 15, 19-21 (1869); The Siren, 74 US (7 
overbroad and intellectually slovenly, no doubt the product of his indignation that a Lee heir was about to reclaim the family manor.

However shoddy Gray's effort, it found a lasting reprise with Bradley in Hans. Building on the confusion of sovereign immunity and the Eleventh Amendment that Gray had started, Bradley fused the concepts of state sovereign immunity and the Eleventh Amendment as a seemingly principled way to let Louisiana escape the consequences of its debts. Reasoning that it would be "anomalous" to restrict the amendment to its literal scope since the amendment had been intended to secure the prior understanding of a general grant of state sovereign immunity, ${ }^{389}$ Bradley simply ignored history and created the myth of the Eleventh Amendment's union with state sovereign immunity.

Bradley could have taken an entirely different approach. If he had been faithful to Iredell's views, he might have contended that state sovereign immunity was part of the residual state sovereignty preserved by the Tenth Amendment. Congress had the power to abrogate this immunity in the furtherance of the jurisdictional heads created by Article III, but Congress had never clearly done so. Anticipating Atascadero State Hospital v Scanlon ${ }^{390}$ Bradley might have argued that the general federal question jurisdiction created by the 1875 Judiciary Act was not sufficiently plain and unambiguous in its intent to abrogate that immunity. Had this been the thrust of Hans, the monkey of southern bond repudiation would have been placed on Congress's back. Moreover, state sovereign immunity would have acquired a doctrinal sense that it now lacks. Congressional abrogation would be a simple matter: whenever Congress acts pursuant to any of its powers it could remove the claim of state immunity inherent in the Tenth Amendment concept of residual state sovereignty. Similarly, the notion of a state's consent to suit would not carry with it the uncomfortable baggage that a party can unilaterally expand the Article III jurisdictional limits of the federal courts.

In fact, courts after Hans have acted very much as if the case had announced a Tenth Amendment immunity rule, rather than one grounded in the Eleventh Amendment. ${ }^{391}$ Sixteen years later,

Wall) 152, 153-55 (1868) (limiting the sovereign immunity of the United States to governmental functions).

389 Hans, 134 US at 10-11.

300473 US 234 (1985).

391 Justice Blackmun has also come to this conclusion. See Atascadero State Hospital, 473 US at 303 (Blackmun dissenting) (quoted in note 23). 
in Gunter $v$ Atlantic Coast Line Railroad ${ }^{392}$ the Court thought the proposition that a state may waive its immunity was elementary. Even prior to Hans, the Court had declared Eleventh Amendment immunity to be "a personal privilege which ... [a state] may waive at pleasure." ${ }^{393}$ If the Eleventh Amendment is a pure denial of jurisdiction, such decisions make no sense. If these decisions respond to waivers of retained Tenth Amendment sovereignty, they make a great deal of sense. ${ }^{394}$

In Monaco $v$ Mississippi ${ }^{395}$ the Court rejected the idea that:

the letter of the Eleventh Amendment exhausts the restrictions upon suits against non-consenting States. Behind the words of constitutional provisions are postulates which limit and control. ... There is ... the postulate that States of the Union, still possessing attributes of sovereignty, shall be immune from suits, without their consent, save where there has been 'a surrender of this immunity in the plan of the convention. ${ }^{396}$

Putting aside the validity of Monaco's perceived postulate, ${ }^{397}$ this passage frankly embraces sovereign immunity as a concept existing outside "the letter of the Eleventh Amendment."

Monaco is not an aberration. To the Welch plurality:

[T] he doctrine of sovereign immunity plays a vital role in our federal system. The contours of state sovereign immunity are determined by the structures and requirements of the federal system. ... The rationale has been set out most completely in the Court's unanimous opinion . . . in Monaco v Mississippi .... The Court has never questioned this basic framework $\ldots .^{388}$

That framework, of course, is one that the Court admits is found largely outside the text of the Eleventh Amendment.

${ }^{392} 200$ US 273 (1906).

${ }^{303}$ Clark v Barnard, 108 US 436, 447 (1883).

${ }^{304}$ The concept of state waiver of its sovereign immunity first developed in the heat of the Southern "bond wars," the same time when the Eleventh Amendment was being transformed into a broad Tenth Amendment doctrine. See Clark $v$ Barnard, 108 US 436 (1883). The nonexistence of the state waiver concept during the development of Eleventh Amendment law in the Marshall and Taney Courts is a further suggestion that, in that era, the amendment was seen as purely jurisdictional.

s9s 292 US 313 (1934).

${ }^{396}$ Id at $322-23$ (footnote omitted) (quoting Federalist 81 (Hamilton)).

${ }^{307}$ See text at notes $388-91$.

${ }^{398}$ Welch, 107 S Ct 2941, 2953. 


\section{Implications of Reconceiving SOVEREIGN IMMUNITy AND THE ELEVENTH AMENDMENT}

\section{A. Sovereign Immunity as a Tenth Amendment Doctrine}

While the present Court is loath to admit it, the Monaco Court's framework of state sovereign immunity is textually rooted in the Tenth Amendment, a provision admirably suited to this purpose. ${ }^{399}$ Its function is to address and define the sovereignty relationships between the people, the states, and the national government. It does this by placing limits on governments and presuming that sovereignty flows from the people to the governments they form in accord with the wishes of the people. "The powers not delegated to the United States by the Constitution, nor prohibited by it to the States, are reserved to the States respectively, or to the people." The national government is confined to its delegated powers. State governments are barred from exercising those powers prohibited by the Constitution or those delegated to the national government that have been exercised so as to preempt state authority. Everything else is "reserved to the States respectively, or to the people."

Here, at last, is the kernel of truth. The states exercise sovereignty to the extent that it has been conferred upon them by the people. The state constitutions mediate between the people and their state agents. Those powers not granted to a state by its people in the state constitution are "reserved ... to the people." the extent that a state constitution fails to grant immunity to the people's agents-the state government-the state lacks immunity in either state or federal court. ${ }^{402}$ By their refusal to clothe their state government with immunity, the people have simply reserved

soo The revisionists and I share some common ground here, although we may disagree on the meaning of Tenth Amendment state sovereign immunity. See Fletcher, 35 Stan L Rev at 1108-13 (cited in note 2); Amar, 96 Yale L $J$ at 1484-92 (cited in note 2).

400 The theory advanced here does not depend on freestanding notions such as "federalism" or "state sovereignty" being rooted in the Tenth Amendment. Rather, the theory views the content of the amendment as being defined by the limits of Article I congressional powers. Some of the problems that arise in the context of limitations on Article III powers are therefore avoided. Whether such freestanding notions could apply in the sovereign immunity context is beyond the scope of this theory.

101 See Story, 3 Commentaries on the Constitution of the United States $\S 1900$ at 75253 (1833) (state constitutions are the dividing line between Tenth Amendment rights reserved to the states and those reserved to the people).

102 Of course, this view requires abandonment of the conventional notion that a state's waiver of immunity in its own courts does not operate as a waiver of Eleventh Amendment immunity in the federal courts. See Pennhurst, 465 US 89, 99 n 9 (1984); Smith v Reeves, 178 US 436, 441 (1900). 
the power that immunity would confer.

If a state's constitution does contain a grant of immunity, ${ }^{403}$ then the state is immune from liability in its own courts except where the people, acting as a single national unit, have contravened the state choice through the national Constitution's Supremacy Clause and the exercise by Congress of its delegated powers. ${ }^{404}$ In federal court, the state's immunity depends on whether the claim is rooted in the Constitution or a federal statute. If Congress has acted to abrogate the state's immunity pursuant to its delegated powers, the state is amenable to suit. If Congress has not so acted, the grant of immunity is a power "reserved to the State[]." But if the state has exercised a constitutionally prohibited power it is amenable to suit, for its unconstitutional grab of power "cannot be corrected, without a suit against the state."405

The doctrine of state amenability to federal suit for constitutional violations derives even more force from the Fourteenth Amendment. In the wake of incorporation of most of the Bill of Rights into the Fourteenth Amendment's Due Process Clause, constitutional prohibitions upon state powers have been greatly expanded. Unlawful state excursions into the arena of these newly prohibited powers are just as surely beyond the zone of Tenth Amendment immunity as any other attempt to employ a prohibited power. States are as surely prohibited from forcing criminal defendants to incriminate themselves as they are from coining money.

There are thus three considerations involved in assessing Tenth Amendment state sovereign immunity. First, there is no immunity unless a state government has been invested with such immunity by its people in its state constitution. Second, that immunity is held at the grace of Congress: so long as Congress has not acted under its delegated powers to abrogate state immunity, a state retains its immunity. Finally, immunity may be abrogated by the Constitution's prohibitions upon state power, both in the original Constitution and through the Fourteenth Amendment. Unlike the Fitzpatrick $v$ Bitzer $^{406}$ rationale, however, in Tenth Amend-

${ }^{103}$ This grant of immunity may be explicit in the text of the state constitution (for example, see Penn Const, Art I, $\S 11$ (quoted in note 150), or it may be judicially created. The federal courts would, of course, be bound by the interpretation of the state constitution by the highest state court.

104 See text at-notes 391-98.

${ }^{105}$ Chisholm v Georgia, 2 US (2 Dall) 419, 422 (1793) (oral argument of Edmund Randolph).

${ }^{108} 427$ US 445 (1976). See text at notes $47-49$. 
ment sovereign immunity there is no need for Congress to act pursuant to $\S 5$ of the Fourteenth Amendment, although such statutory action would surely be efficacious to eradicate a state's claimed immunity. The prohibitions upon the states imposed by $\S$ 1 of the Fourteenth Amendment are self-executing abrogations of such immunity.

\section{B. The Eleventh Amendment as a Party-Based Denial of Jurisdiction}

If the Eleventh Amendment is reconceived as a party-based jurisdictional ouster provision and state sovereign immunity as an attribute of Tenth Amendment sovereignty, federal statutory and constitutional claims may be asserted against states by their own citizens but not by foreigners or citizens of another state. Short of outright repeal of the Eleventh Amendment, how are we to solve this anomaly?

One solution is to build upon the analytical edifice of Testa $v$ $K a t t,{ }^{407}$ which compels state courts to hear suits seeking to enforce substantive rights created under federal law whenever the state would entertain a parallel substantive claim under state law. The Court in Testa did not actually hold that state courts must hear federal causes of action that are barred in federal court, nor did it implicate any issues of state sovereign immunity, since the case involved only private litigants. Rather, the holding in Testa commands states to provide a state forum for federal claims to the extent the state courts would entertain parallel state claims under established jurisdictional rules of local law. Thus, a state could theoretically deny a forum for a private federal claim against the state on the ground that, pursuant to its sovereign immunity from suit in its courts, it does not permit parallel private state claims. However, General Oil Co. $v$ Crain ${ }^{408}$ suggests that this obligation may not be so evaded. Similarly, Justice Thurgood Marshall thinks

107330 US 386 (1947).

${ }^{108} 209$ US 211, 226 (1908). A taxpayer had sought to enjoin, in the Tennessee courts, collection of an allegedly unconstitutional state tax. The Tennessee Supreme Court held that the Tennessee courts had no jurisdiction. On appeal, the United States Supreme Court determined that the tax was valid and so never reached the issue of whether Tennessee could deny General Oil a forum for the vindication of its claimed constitutional right. The Court did observe, however, that if it was permissible for Tennessee to close its courthouse doors on claims barred from the federal courts by the Eleventh Amendment "it must be evident that an easy way is open to prevent the enforcement of many provisions of the Constitution, and the Fourteenth Amendment, which is directed at state action, could be nullified as to much of its operation." Id. 
that since the Eleventh Amendment is "nothing more than a regulation of the forum" and that "federal law stands as the supreme law of the land, the State's courts are obliged to enforce it, even if it conflicts with state policy" and the states are obliged to open their courts to private claims against them rooted in federal law. ${ }^{409}$

Professor Tribe regards Justice Marshall's view as an improper application of Testa, ${ }^{\mathbf{4 1 0}}$ and Professor Fletcher thinks Marshall's view is at odds with the intentions of the adopters of the Eleventh Amendment. Fletcher points out the overwhelming Congressional rejection of a proposal to suspend operation of the Eleventh Amendment in those instances where a state had failed to provide a forum for the private claim against the state. ${ }^{411}$ While the proposal may have implied a fear that private claims against states would go unremedied, its rejection says very little about the theoretical existence of an independent obligation of the states to provide fora for the vindication of federal rights. Given the then prevailing assumption that federal question jurisdiction was left to state courts, it is doubtful that this rejection can be read as a final repudiation of the principle that state courts must provide a forum for federal claims. The nation operated for nearly a century without federal question jurisdiction in the federal courts, relying on the premise that state courts would apply federal law to vindicate federal claims. ${ }^{412}$ Thus, there is nothing disharmonious in Congressional action to compel the states to provide such a forum for the vindication of federal rights.

If these judicial intimations are extended and combined with a reconstituted view of sovereign immunity as a Tenth Amendment right, a partial solution emerges in which Congress plays a vital role. Even though a state has acquired sovereign immunity in its own courts by its own constitution, Congress may act to abrogate that immunity so long as it acts pursuant to its delegated powers. Thus, Congress need only enact legislation that unequivocally abrogates the sovereign immunity of all states with respect to claims

${ }^{408}$ Employees v Missouri Public Health Dept., 411 US 279, 298 (1973) (Marshall concurring). Some commentators also contend that Congress could require state courts to hear cases barred from the federal courts by the Eleventh Amendment. See Louis F. Wolcher, Sovereign Immunity and the Supremacy Clause: Damages Against States in Their Own Courts for Constitutional Violations, 69 Cal L Rev 189 (1981); Allan D. Cullison, Interpretation of the Eleventh Amendment (A Case of the White Knight's Green Whiskers), 5 Houston L Rev 1, 35 (1967).

410 Tribe, American Constitutional Law at $184 \mathrm{n} 45$ (cited in note 2).

11 Fletcher, 35 Stan L Rev at 1059, 1095 \& n 243 (cited in note 2).

${ }^{412}$ See note 280. Compare Martin v Hunter's Lessee, 14 US (1 Wheat) 304 (1816). 
made against them by out-of-staters that are founded upon federal statutes, treaties, or the Constitution. But since the Eleventh Amendment bars Congress from conferring jurisdiction upon the federal courts over such suits, Congress could only demand, pursuant to the Supremacy Clause, that states afford all such litigants a state forum. Of course, in order to assure even-handedness, review of such state judgments would be available in the United States Supreme Court.

While the solution of forcing states to provide a forum for vindication of federal claims made by non-citizens may not be ideal, it is likely that not every state court will exhibit open hostility to claims made against it by a non-citizen. If state immunity were to be reconceived in the fashion urged here, states would soon grow accustomed to the posture of defendant in both federal and state courts. In time, the employment of the state forum for such federal claims asserted by non-citizens would become simply a quaint vestige of the eighteenth century reaction to Chisholm.

Of course, this solution is jerry-rigged; the proper solution is repeal of the Eleventh Amendment. Were that course of action taken, state sovereign immunity would become a wholly Tenth Amendment problem devoid of the jurisdictional anomaly created by the Eleventh Amendment. State sovereign immunity with respect to federal statutory claims would ebb and flow with the actions of Congress under its delegated powers. More importantly, claims of private citizens against states founded on the Constitution would always be assertable in federal court, without the necessity of congressional action. The benefit, if any, to the proposed interim solution is that it would both insure the existence of a forum for all claims against states and would highlight the jurisdictional absurdity of the Eleventh Amendment.

\section{Pennsylvania $v$ Union Gas Co.: An Application of the Theory}

On the Supreme Court's docket for the October 1988 Term is Pennsyluania $v$ Union Gas Co., ${ }^{413}$ a case that provides a handy vehicle for exploring the proposed theory. Under prevailing Eleventh Amendment doctrine, Union Gas presents a narrow, albeit important, issue: the scope of congressional power under Article I to abrogate the states' Eleventh Amendment immunity. In the 1986 amendments to the "Superfund" legislation Congress appar-

413 Cert granted, $108 \mathrm{~S}$ Ct 1219 (1988), reported below as, United States v Union Gas Co., 832 F2d 1343 (3d Cir 1987). 
ently stripped the states of their Eleventh Amendment immunity in suits seeking to recover from owners or operators of toxic waste sites the monetary costs for cleaning up the sites. ${ }^{414}$ If the Court concurs that Congress intended to do just that, it will then be required to address directly the scope of congressional abrogation power. It may do this in one of several distinctly different ways.

First, the Court may leave intact the conventional post-Hans view of the Eleventh Amendment as a source of a waivable state immunity doctrine, and simply focus on the scope of congressional Article I powers. This approach has been adopted by the federal appeals courts that have confronted the question ${ }^{415}$ and is favored as well by such commentators as Professors Tribe and Nowak, who contend that the Eleventh Amendment was not intended to limit congressional Article I powers, but only to limit the judicial power in construing the scope of the Article III jurisdictional grant. ${ }^{416}$ In Union Gas, this approach also necessarily requires examination of the contention that "only the amendments following the eleventh may override it,"417 since Superfund was enacted pursuant to Congress' Commerce Clause power.

The fundamental problem with this analytical method is that any result that retains the Hans doctrine will be flawed. It is historically inaccurate to conclude that the Eleventh Amendment did not intrude upon congressional power under Article I. Rather, be-

\$14 The original "Superfund" act, entitled the Comprehensive Environmental Response, Compensation and Liability Act, is codified at 42 USC $\$ 9601$ et seq (1982). In 1986, Congress amended the statute via the Superfund Amendments and Reauthorization Act of 1986, Pub L No 99-499. The original Superfund legislation permitted private suits for recovery of clean-up costs against "any person" who owned or operated a toxic waste site. 42 USC \$ 9607(a) (1982). While the statute defined "any person" to include states, 42 USC $\$ 9601(21)$ (1982), the statute was nevertheless read as failing to abrogate state immunity because, other than the definitional inclusion, it lacked a clear and explicit abrogation of such immunity. See United States v Union Gas Co., 792 F2d 372, 380 (3d Cir 1986). Most persuasive to the court was the fact that the original Superfund Act contained an express waiver of federal sovereign immunity, 42 USC $\$ 9607(\mathrm{~g})$ (1982), but no parallel abrogation of state immunity. That defect may have been remedied in the 1986 Superfund amendments. See 42 USC $\$ 9601(20)(D)$ (Supp 1987) and United States $v$ Union Gas Co., 832 F2d 1343, 1348-50 (3d Cir 1987).

415 See cases cited in note 50.

${ }^{416}$ See Tribe, American Constitutional Law 185-89 (cited in note 2); Laurence $\mathrm{H}$. Tribe, Intergovernmental Immunities in Litigation, Taxation and Regulation: Separation of Powers Issues in Controversies About Federalism, 89 Harv L Rev 682, 693-99 (1976); Nowak, 75 Colum L Rev at 1442, 1469 (cited in note 2).

417 Union Gas, 832 F2d at 1351 (discussing the theory of Fitzpatrick $v$ Bitzer, 427 US 445 (1976), which held that Congress may waive state immunity pursuant to its powers granted in the Fourteenth Amendment since the Fourteenth Amendment effectively "amended" the Eleventh.) 
cause it was intended as a device to oust jurisdiction, the amendment necessarily prohibits Congress from vesting the federal courts with jurisdiction over suits against states brought by out-of-staters, even when the subject matter of such suits involves questions of federal law enacted pursuant to an uncontested Article I power. Moreover, this method completely fails to address the deeply rooted conceptual error of Hans. If the Court treats the Eleventh Amendment as a jurisdictional rule, it cannot simultaneously retain the Hans fiction that this jurisdictional limitation can be waived by a state or abrogated by Congress. Yet, if the Court rejects reading the Eleventh Amendment as jurisdictional, it perpetuates historical error and ignores the legal text.

Second, the Court could repudiate the Hans doctrine and adopt the revisionist approach that the Eleventh Amendment has no applicability to actions founded on federal question jurisdiction, as is Union Gas's claim against Pennsylvania. The advantage of this approach is its conceptual neatness and simplicity. If no state sovereign immunity exists with respect to federal question claims there is no need to inquire into the limits of the congressional abrogation power. Moreover, the federal forum would be open to all litigants asserting a claim against a state founded on a federal question, whatever their citizenship. The principal disadvantage of this approach is that it is not congruent with the text, history of the adoption, and early interpretation of the Eleventh Amendment.

Third, the Court could apply the theory advocated here. Construction of the amendment as a jurisdictional ouster provision requires repudiation of the Hans doctrine. With the demise of the Hans doctrine and its notion that state immunity is rooted in the Eleventh Amendment, the Court would be forced to either locate that principle elsewhere in the constitutional design or abandon it altogether. Relocation of the immunity principle in the Tenth Amendment makes the case relatively easy. Since the Eleventh Amendment operates to oust the federal courts of jurisdiction of all claims made against a state by an out-of-stater, and Union Gas is a Pennsylvania citizen, ${ }^{\mathbf{4 1 8}}$ its claim is not foreclosed. Pennsylvania's claim of immunity from suit is bound up in its residual sovereignty preserved by the Tenth Amendment. If Pennsylvania's Constitution had failed to confer immunity from suit by its citizens upon the state there would have been no need to examine the elu-

118 Telephone conversation with Robert A. Swift, counsel for Union Gas Co., October 12, 1988. 
sive frontier between the Tenth Amendment and congressional power under Article I. But since Pennsylvania has such immunity, ${ }^{419}$ the question of state immunity will turn on whether congressional action in the 1986 Superfund amendments abrogating state immunity is properly within the scope of the commerce power delegated to Congress. That is an issue beyond this article, yet were the focus placed there, the structure of the constitutional design would be more clearly examined. Since the underlying policy of the conventional Hans formulation is to limit the encroachment upon state sovereignty of federal power, the theory advanced here accomplishes that objective in a more straightforward manner. It focuses thought where it should be-upon the frontier between legitimate exercise of delegated powers and the retained sovereignty of the states.

\section{Conclusion}

The conventional view that the Eleventh Amendment states a constitutional rule immunizing states from private suit in federal court without their consent or congressional action to abrogate their immunity is flawed conceptually and historically. Its conceptual error lies in the perversion of a constitutional amendment that limits federal court jurisdiction into a privilege that may be waived or abrogated. If the amendment is jurisdictional, this conceptual baggage is offensive to long-settled notions of subject matter jurisdiction. If the amendment is not jurisdictional, a very long step has been taken beyond "non-interpretive" constitutional adjudication; we have now ventured into a twilight zone where plain text is to be ignored.

The conventional treatment of the Eleventh Amendment has been sharply criticized, yet the alternative, revisionist view advanced by the critics is almost as deficient. The revisionists seek to reconstrue the Eleventh Amendment into an innocuous pruning of diverse party jurisdiction, without having any effect on federal question jurisdiction. While this exercise is appealing in its simplicity-eliminating problems created by reading the Eleventh

419 Article I, § 11 of the Pennsylvania Constitution provides that "[s]uits may be brought against the Commonwealth in such manner, in such courts, and in such cases as the Legislature may by law direct." An identical provision appeared in the prior Pennsylvania Constitutions of 1790 and 1838. The provision has been interpreted by the Pennsylvania courts to mean that Pennsylvania is immune from suit without its consent. See Commonwealth v Berks County, $364 \mathrm{~Pa} 447,449$ (1950); Bell Telephone Co. of Pa. v Lewis, $313 \mathrm{~Pa}$ 374, 375 (1934); Collins v Commonwealth, $262 \mathrm{~Pa} 572$ (1919). 
Amendment as a jurisdictional ouster-and is consistent with notions of popular sovereignty that surely animated the founding generation, it ignores important historical realities. The Eleventh Amendment was intended to oust the federal courts of jurisdiction even of claims that were rooted in federal treaties or the Constitution. The Supreme Court initially construed the amendment to do just that, and that construction was never repudiated, even by such a nationalist Court as John Marshall's. Moreover, while the founding generation believed in popular sovereignty, there was a division of opinion whether the proper focus of that sovereignty was the undivided people of the nation, or the separate peoples of each constituent state. The Eleventh Amendment represents a partial victory for states-rightists, who succeeded in obtaining a partybased ouster of federal court jurisdiction but could not obtain an explicit recognition of state sovereign immunity. That principle remained where it had always been: in the Tenth Amendment.

The legacy that has been bequeathed to us is irrational. Viewing sovereign immunity as an attribute of residual state sovereignty preserved by the Tenth Amendment simplifies and harmonizes state sovereignty with both federal union and sovereignty of the people. But the Eleventh Amendment remains as a jurisdictional joker that frustrates the realization of a unified state sovereign immunity doctrine under the Tenth Amendment. In order to ameliorate the effects of the Eleventh Amendment it is necessary to push Supremacy Clause doctrine to extreme lengths. A better solution, were there the political will to achieve it, is the repeal of the Eleventh Amendment. Until then, a proper reconceptualization of its role in relation to sovereign immunity would be of service to historical accuracy, state sovereignty as preserved by the Constitution, and, most importantly, to the people, who are the ultimate sovereigns. 
